STÊNIO JOSÉ PAULINO SOARES

O social e o sensível: uma experiência de pensamento a partir do processo poético de Fernando Jackson Ribeiro 
O social e o sensível: uma experiência de pensamento a partir do processo poético de Fernando Jackson Ribeiro

Dissertação apresentada ao Programa de PósGraduação Interunidades em Estética e História da Arte da Universidade de São Paulo, para obtenção do título de Mestre em Estética e História da Arte.

Área de concentração: Estética e História da Arte

Orientadora:

Prof $^{a}$ Dr $^{\mathrm{a}}$. Carmen Sylvia Guimarães Aranha 
AUTORIZO A REPRODUÇÃO E DIVULGAÇÃO TOTAL E PARCIAL DESTE TRABALHO, POR QUALQUER MEIO CONVENCIONAL OU ELETRÔNICO, PARA FINS DE ESTUDO E PESQUISA, DESDE QUE CITADA A FONTE.

\author{
Catalogação da Publicação \\ Biblioteca Lourival Gomes Machado
}

Museu de Arte Contemporânea da Universidade de São Paulo

Soares, Stênio José Paulino.

O social e o sensível : uma experiência de pensamento a partir do processo poético de Fernando Jackson Ribeiro / Stênio José Paulino Soares ; orientadora Carmen Sylvia Guimarães Aranha. -- São Paulo, 2013.

104 f. + anexos : il.

Dissertação (Mestrado - Programa de Pós-Graduação Interunidades em Estética e História da Arte) -- Universidade de São Paulo, 2013.

1. Artes Plásticas - Brasil - Século 20. 2. Escultura - Brasil - Século 20. 3. Crítica de Arte. 4. Sociologia da Arte. 5. Ribeiro, Jackson, 19281997. I. Aranha, Carmen Sylvia Guimarães. II. Título.

CDD 709.81 


\section{O social e o sensível: uma experiência de pensamento a partir do processo poético de Fernando Jackson Ribeiro}

Dissertação apresentada ao Programa de PósGraduação Interunidades em Estética e História da Arte da Universidade de São Paulo para obtenção do título de Mestre em Estética e História da Arte.

Aprovado em: 12 de seetembro de 2013

BANCA EXAMINADORA

Prof $^{a}$ Dra . Carmen Sylvia Guimarães Aranha

MAC/USP - Orientadora

Prof ${ }^{a}$ Dra . Katia Canton Monteiro

MAC/USP - Examinadora

Prof. Dr. José Augusto Costa de Almeida (José Rufino)

DG/CGC/UFPB - Examinador 
Dedico este trabalho a minha mãe, Hilda Paulino Soares, e a meu pai, Delmo Alves Soares. Todo carinho, esforço e dedicação. 


\section{AGRADECIMENTOS}

Todo trabalho empenhado nessa pesquisa seria vazio e nulo sem a força de tantos que me ouviram e contribuíram para esta realização. Minha irmã Hilma Paulino Soares teve uma paciência especial, horas à fio segurando uma barra que assumiu como dela. Durante esse processo, minha avó Maria Alice, que não pode acompanhar finalização desse meu estudo, tornou-se uma pessoa essencial para me despertou outras sensibilidades.

Os familiares do artista Fernando Jackson Ribeiro foram extremamente acolhedores a quem agradeço a importante contribuição nessa pesquisa. Assim como não posso esquecer a atenção e apoio, ao desenvolvimento do estudo, dados pelos gestores dos acervos museológicos e responsáveis pelos arquivos envolvidos nessa pesquisa, em especial à Alice Milliet, Dyógenes Chaves, À Diretoria do Museu Casa de José Américo, À equipe do Museu de Arte Contemporânea do Paraná, Amália Geisel, (MAC), Márcio Doctors e Gloria Ferreira.

Aos amigos da Pós-graduação que me acompanharam nos momentos mais interativos da vida acadêmica quando compartilhamos nossa experiência de pensamento - Paulo Marquezzini, Lisa Oliveira, Marina Barão, Águida Mantegna, Joanna D`Arc e, em especial, minha grande companheira Desirée Tozi Ramos;

Nessa etapa de formação acadêmica tive uma especial atenção e comunhão de pensamento com os mestres Marilena Chaui (FFLCH/USP), Kátia Canton (MAC/USP), Sérgio Martins (FAU/USP), Leon Kossovisth (FFLCH/USP). Além das contribuições de Lisbeth Rebollo (ECA/USP), Cristina Freire (MAC/USP). As orientações da banca de qualificação do trabalho foram o marco para esta pesquisa e agradeço especialmente à Kátia Canton e à Alexsandra Martins (MAC/USP);

Viver mais de quatro na selva de concreto paulistana não seria possível se não existissem pessoas que de alguma maneira me fizessem olhar São Paulo de uma maneira diferente. Sou grato aos meus amigos, em especial aos amigos uspianos Rafael Bacarolo e Gabriela Dias;

Ainda distantes, grandes amigos lembravam-me o verdadeiro sentido da amizade Fernandinha Checchinato, Israel Luna, Priscila Luna, Germana Almeida, Lorena Borges, Luciana Souto, Bárbara Wanderley e Flávio Lira; 
Agradeço à Capes pelo incentivo financeiro dado à pesquisa.

E, por fim, com especial importância, agradeço a minha orientadora pela paciência no trabalho com o aprendiz, à pesquisadora pela dedicação e co-autoria deste trabalho, a minha especial amiga pela força de sempre, Carmen Sylvia Guimarães Aranha. 
Pensar é um ato. Sentir é um fato. Os dois juntos - sou eu que escrevo o que estou escrevendo. Deus é o mundo. A verdade é sempre um contato interior e inexplicável. A minha vida a mais verdade é irreconhecível, extremamente interior e não tem uma só palavra que a signifique. (LISPECTOR, Clarice. A hora da estrela. Rio de Janeiro: Rocco, 1998, p. 11.) 


\section{RESUMO}

SOARES, S. J. P. O social e o sensível: uma experiência de pensamento a partir do processo poético de Fernando Jackson Ribeiro. 2013. 100 f. Dissertação (Mestrado) Programa de Pós-Graduação Interunidades em Estética e História da Arte, Universidade de São Paulo, 2013.

A presente dissertação é uma reflexão a partir do processo poético de Fernando Jackson Ribeiro, isso quer dizer que entendemos que a criação artística é capaz de despertar uma experiência de pensamento. Nossa reflexão foi orientada a partir da percepção de uma realidade interna, construída a partir da relação intersubjetiva artista/obra de arte/observador. Nesse sentido, entendemos que esta relação intersubjetiva é o princípio racional que justifica a existência da realidade interna percebida, que tratamos como social e sensível. Duas questões são fundamentais para o desenvolvimento da nossa dissertação: 1) O que é essa relação entre o social e o sensível que ganha visualidade na obra de Jackson Ribeiro? 2) Como são construídas e como se dinamizam as relações intersubjetivas artista/obra de arte/observador, no nosso caso, Jackson Ribeiro/social-sensível/pesquisador? Para responder essas questões propomos um recorte histórico que objetiva abranger a produção do artista entre anos 1959 e 1984. Assim, temos a intenção de situar a expressão artística de Ribeiro dentro do período em que ele estabelece uma comunicação da sua obra através de exposições e salões de arte. Buscamos assinalar quais elementos da sua produção possibilitam a visualidade da relação entre o social e o sensível. Entendemos que o social e o sensível é um fenômeno, que ganha visualidade através da linguagem de Jackson Ribeiro e da experiência que o observador tem com a obra de arte. Assim como entendemos que as relações intersubjetivas que fundam esse fenômeno de visualidade são experiências com o Ser da linguagem, que tem que como pano de fundo a historicidade dos indivíduos e o contexto por eles vivido. Dessa maneira, podemos entender a experiência a partir da obra de arte como uma forma de pensamento.

Palavras-chaves: Artes visuais; escultura; Jackson Ribeiro; Crítica de arte; fenomenologia. 


\section{RESUMÉ}

SOARES, S. J. P. Le social et le sensible: une experience de la pense apartir du processus poétique de Fernando Jackson Ribeiro. 2013. 100 f. Dissertação (Mestrado) - Programa de Pós-Graduação Interunidades em Estética e História da Arte, Universidade de São Paulo, 2013.

Cette dissertation est une réflexion à partir du processus poétique de Fernando Ribeiro Jackson, cela signifie que nous comprenons que la création artistique est capable de réveiller une expérience de pensée. Notre réflexion s'est orientée à partir de la perception d'une réalité intérieure, construite à partir de la relation intersubjective - l'artiste / l'œuvre d'art / le spectateur. En conséquence, nous croyons que cette relation intersubjective est le principe rationnel qui justifie l'existence de la réalité intérieure perçue, que nous considérons comme sociale et sensible. Deux questions sont fondamentales pour le développement de notre dissertation: 1) Quelle est la relation entre le sociale et le sensible qui est rendu visible dans l'œuvre de Jackson Ribeiro? 2) Comment sont construits et comment se rationalisent leurs relations intersubjectives l'artiste / l'oeuvre d'art / le spectateur, dans notre cas, Jackson Ribeiro / sociale-sensible / chercheur? Pour répondre à ces questions, nous proposons un étude qui rende compte de la production de l'artiste entre les années 1959-1984. Ainsi, nous avons l'intention de situer l'expression artistique de Ribeiro dans la période dans laquelle il établit une communication de son œuvre à travers des expositions et salons d'art. Nous cherchons à souligner les éléments de leur production que rende visible la relation entre le social et le sensible. Nous comprenons que le social et le sensible est un phénomène qui rendre visible à travers de la langage Jackson Ribeiro et l'expérience du spectateur entretient avec l'œuvre d'art. Comme nous comprenons que les relations intersubjectives qui soustendent ce phénomène sont des expériences visuelles avec l'être du langage, qui doivent en toile de fond l'historicité des individus et le contexte dans lequel ils vivaient. Ainsi, nous pouvons comprendre l'expérience avec l'œuvre d'art comme une forme de la pensée..

Mots-clés: les arts visueles; le sculpture; Jackson Ribeiro; critique de l'art ; phénomenologie. 


\section{LISTA DE FIGURAS}

Figura 1 - RIBEIRO, Jackson. Elementar 5, 1960, pedra e ferro, 59,6x49x31,7cm. Acervo Museu de Arte Contemporânea da Universidade de São Paulo. Foto: Arquivo MAC USP.

Figura 2 - RIBEIRO, Jackson. Elementar 4, 1961. Ferro e pedra. 26 x 51 x $25 \mathrm{~cm}$. Acervo da Fundação José e Paulina Nemirovsky. Foto: acervo Fundação José e Paulina Nemirovsky.

Figura 3 - RIBEIRO, Jackson. Fausto, 1964, ferro, 165 x 120 x 89 cm. Acervo Museu Nacional de Belas Artes. Foto: Acervo do Museu Nacional de Belas Artes.

Figura 4 - RIBEIRO, Jackson. Construção XIV, 1967, Alumínio. Acervo Museu de Arte Moderna do Rio de Janeiro. Foto: Museu de Arte Moderna do Rio de Janeiro.

Figura 5 - RIBEIRO, Jackson. Sem título, (?), Ferro. Acervo Museu de Arte Moderna do Rio de Janeiro. Foto: Museu de Arte Moderna do Rio de Janeiro.

Figura 6 - RIBEIRO, Jackson. Sem título, (?), Ferro. Acervo Museu de Arte Moderna do Rio de Janeiro. Foto: Museu de Arte Moderna do Rio de Janeiro.

Figura 7 - RIBEIRO, Jackson. Construção 3, 1972, Alumínio. Acervo Museu de Arte Moderna de São Paulo. Foto: Museu de Arte Moderna de São Paulo.

Figura 8 - RIBEIRO, Jackson. Sem título múltiplo II, [1972], ferro. Museu Casa de José Américo. Foto: CENTRO Empresarial Rio. FOTO: CENTRO Empresarial Rio Catálogo da exposição Jackson Ribeiro Os Elementares: 29 de fevereiro a 7 de abril de 1984. Rio de Janeiro: Centro Empresarial Rio, 1984.

Figura 9 - RIBEIRO, Jackson. Sem título. [1972], ferro. Museu Casa de José Américo. Foto: Acervo Museu Casa de José Américo.

Figura 10 - RIBEIRO, Jackson. Decorrências Modulares, 1979. Obra/projeto. Ferro, alumínio e madeira. Acervo do Museu de Arte Contemporânea do Paraná. Foto: Arquivo do artista (Museu de Arte Contemporânea do Paraná).

Figura 11 - RIBEIRO, Jackson. Sem título (Série A), 1990, Serigrafia sobre papel, 31 cópias, (32,7x23,6cm). Acervo do Museu de Arte Contemporânea do Paraná. Foto: acervo Museu de Arte Contemporânea do Paraná. 
Figura 12 - RIBEIRO, Jackson. Sem título (Série B), 1990, Serigrafia sobre papel, 31 cópias, $(32,7 \times 23,6 \mathrm{~cm})$. Acervo do Museu de Arte Contemporânea do Paraná. Foto: acervo Museu de Arte Contemporânea do Paraná.

Figura 13 - Assemblage de Jackson Ribeiro. Tecido, moldura, Decorrências Modulares e fotografia. [1980?]. Foto: Arquivo do artista - Museu de Arte Contemporânea do Paraná.

Figura 14 - Pintura de Jackson Ribeiro, 1958 [?]. Foto: Arquivo do artista - Museu de Arte Contemporânea do Paraná.

Figura 15 - RIBEIRO, Jackson. Crucifixo, 1959. Ferro. Objeto múltiplo. Foto: Arquivo do Artista - Museu de Arte Contemporânea do Paraná.

Figura 16 - RIBEIRO, Jackson. Decorrências modulares, 1993. Óleo s/ madeira. Museu de Arte Moderna do Rio de Janeiro. Foto: Museu de Arte Contemporânea do Rio de Janeiro.

Figura 17 - RIBEIRO, Jackson. Decorrências Modulares, (?). Pintura sobre madeira. Foto: Arquivo do artista (Museu de Arte Contemporânea do Paraná).

Figura 18 - RIBEIRO, Jackson. Decorrências Modulares, (?). Objeto. Foto: Arquivo do artista (Museu de Arte Contemporânea do Paraná).

Figura 19 - RIBEIRO, Jackson. Decorrências Modulares, (?). Pintura sobre madeira. Foto: Arquivo do artista (Museu de Arte Contemporânea do Paraná).

Figura 20 - RIBEIRO, Jackson. Troféu "Homem de vendas", 1984. Objeto. Foto: Arquivo do artista (Museu de Arte Contemporânea do Paraná).

Figura 21 - APRESENTAÇÃO da obra Porteiro do infeiro, 1965. Da esquerda para a direita vê-se o crítico de arte Raul Córdula (primeiro) e Jackson Ribeiro (terceiro). Foto: Arquivo do artista (Museu de Arte Contemporânea do Paraná)

Figura 22 - RIBEIRO, Jackson. Porteiro do inferno, 1967, obra pública instalada na Av. Getúlio Vargas. Foto: Museu de Arte Contemporânea do Paraná).

Figura 23 - RIBEIRO, Jackson. Porteiro do inferno, 1965. Ferro. Obra pública instalada atualmente em uma das rotatórias ao lado da UFPB, em João Pessoa. Foto: Arquivo do artista (Museu de Arte Contemporânea do Paraná). 
Figura 24 - RIBEIRO, Jackson. Sem título, (1964?). Ferro. Foto: OITICICA, Hélio. Nota sobre a escultura de Fernando Jackson Ribeiro. Rio de Janeiro, 1964. Disponível em:

<http://www.itaucultural.org.br/aplicexternas/enciclopedia/ho/index.cfm?fuseaction=do cumentos\&cod=2\&tipo=2>. Acesso em: 02 jun. 2008.

Figura 25 - RIBEIRO, Jackson. Sem título, (1964?). Ferro. Foto: OITICICA, Hélio. Nota sobre a escultura de Fernando Jackson Ribeiro. Rio de Janeiro, 1964. Disponível em:

<http://www.itaucultural.org.br/aplicexternas/enciclopedia/ho/index.cfm?fuseaction=do cumentos\&cod=2\&tipo=2>. Acesso em: 02 jun. 2008.

Figura 26 - RIBEIRO, Jackson. RIBEIRO, Jackson. Sem título, [1968?]. Ferro. Foto: Arquivo do artista (Museu de Arte Contemporânea do Paraná).

Figura 27 - RIBEIRO, Jackson. RIBEIRO, Jackson. Sem título, [1968?]. Ferro. Foto: Arquivo do artista (Museu de Arte Contemporânea do Paraná). 


\section{LISTA DE GRÁFICOS}

Gráfico 1 - Processo poético de Jackson Ribeiro (Gráfico nosso). 


\section{LISTA DE SIGLAS}

ABCA Associação Brasileira de Críticos de Arte

AICA Associação Internacional de Críticos de Arte

FAFI Faculdade de Filosofia da Paraíba

FUNJOPE Fundação Cultural de João Pessoa

MAC USP Museu de Arte Contemporânea da Universidade de São Paulo

MAC PR Museu de Arte Contemporânea do Paraná

MAM Rio Museu de Arte Moderna do Rio de Janeiro

MAM SP Museu de Arte Moderna de São Paulo

MNBA Museu Nacional de Belas Artes

UFPB Universidade Federal da Paraíba

USP Universidade de São Paulo 


\section{SUMÁRIO}

1. INTRODUÇÃO 16

2. O PROCESSO POÉTICO DE FERNANDO JACKSON RIBEIRO 21

2.1 Os acervos museológicos e os caminhos da construção da linguagem 22

2.2 "A moldura tem que completar o quadro": o ofício de moldureiro-artista 36

2.3 Aproximações e contaminações entre artes visuais e design 40

2.4 Reflexões sobre as relações entre artes visuais, arquitetura e cidade: $o$ caso da obra pública $O$ Porteiro do Inferno $\quad 50$

3. AS EXPERIÊNCIAS DE PENSAR A OBRA DE JACKSON RIBEIRO

3.1 As experiências de leitura da obra feitas pelos críticos de arte 59

3.2 Entre o moderno e o contemporâneo: a obra de Jackson Ribeiro como $\begin{array}{ll}\text { uma vertente construtiva brasileira } & 70\end{array}$

4. O SOCIAL E O SENSÍVEL 80

4.1 "Uma poesia surda e rouca": visualidades como experiência do olhar 83

4.2 O social envolvido pelo sensível ou uma construção metodológica de compreensão da obra de arte

5. CONSIDERAÇÕES FINAIS: UMA EXPERIÊNCIA DE PENSAMENTO A PARTIR DA EXPERIÊNCIA COM A OBRA DE ARTE 94

$\begin{array}{ll}\text { REFERÊNCIAS } & 97\end{array}$

ANEXO I

ANEXO II

ANEXO III

ANEXO IV

ANEXO V

ANEXO VI

ANEXO VII

ANEXO VIII

ANEXO IX

ANEXO X 


\section{INTRODUÇÃO}

J'ai comencé de réfléchir, ma réflexion est réflexion sur un irréfléchi, elle ne peut pas s'ignorer elle-même comme événement, des lors elle s'apparaît comme une véritable création, comme un changement de structure de la conscience, et il lui appartient de reconnaître en deçà de ses propres opérations le monde qui est donné au sujet parce que le sujet est donné à lui-même. (MERLEAU-PONTY, 1945, p. IV) ${ }^{1}$.

Nossa percepção da obra de Fernando Jackson Ribeiro aconteceu semelhante ao enunciado supracitado. A criação do artista despertou uma nova reflexão, uma reflexão que não poderia ignorar a si própria como um evento, ela era em si outra criação. Desde então, ao passo que nosso pensamento construía um caminho margeado por questões, ele se permitia à experiências novas e ininterruptas. Mas qual seria a outra criação que falamos?

A partir da observação das criações de Jackson Ribeiro construímos um diálogo artista/criações/observador. Esse diálogo é um terreno de indagações sobre aspectos externos: Quem é o artista? Qual o contexto da sua produção? Quais materiais e como são usados para a criação? Entretanto, os aspectos externos não esgotam as possibilidades de reverberação da obra do artista, pois em meio a estas questões nascem reflexões que a obra nos suscita. Materiais passam a ser compreendidos tal como as letras de um alfabeto, as criações passam a ser vistas como palavras ou expressões e o conjunto das criações passa a ser entendido tal como textos. Antes que a observação se resuma na pura interpretação de uma imagem, percebemos uma nova realidade que se funda, esta realidade é interna e de uma natureza reflexiva, portanto, as questões não são mais dirigidas ao outro, mas a nós mesmos, ao próprio observador. Quem observa? Qual é a época que se observa a criação artística? Quais recursos se dispõem a compreender a criação artística e como se faz? As respostas nos permitem sair de uma zona de conforto e estabelecer uma relação com o objeto de estudo sem tentar sobrepor sujeitos: tanto quem observa a criação artística quanto a criação observada integram o objeto desse estudo. A criação artística é ativa e motivadora, capaz de nos despertar uma reflexão que já é outra criação. Assim, os observadores (pesquisadores) e o observado (a criação artística) se configuram em uma interface objeto/sujeito de pesquisa, submersos pelo

\footnotetext{
1 "Eu comecei a refletir, minha reflexão é reflexão sobre um irrefletido, ela não pode ignorar-se enquanto um acontecimento, assim ela se aparece como uma verdadeira criação, como uma mudança de estrutura da consciência, e se reconhece a partir das próprias operações do mundo que é dado ao sujeito porque o sujeito é dado a si mesmo". (MERLEAU-PONTY, 1945, p. IV)
} 
mesmo mar, molhados pela mesma água, fazendo parte da nossa reflexão filosófica sobre uma realidade interior. A realidade interior percebida não se permite ser negada, tão pouco ela está submissa a uma análise exterior, pois ela não é produto da causalidade: pelo contrário, essa realidade estabelece sua base através da relação intersubjetiva artista/criação/observador.

Como entendemos que essa realidade percebida se funda através de uma relação de intersubjetividade? Primeiramente, não podemos negar que a criação artística expressa a subjetividade do artista, deste modo ela é também expressão artística. Entretanto, a existência da criação artística motiva a reflexão de outros sujeitos, pois a criação/expressão carrega emsi uma intencionalidade. Quando Jackson Ribeiro recolhe um objeto de ferro sucateado e fixao sobre uma pedra, o artista age a partir de uma percepção das formas do ferro e da pedra: ele identifica as formas e as dinamiza no espaço, criando um novo objeto do qual se responsabiliza esteticamente. Este objeto é a sua criação, ele é a expressão da sua percepção e do seu conhecimento sobre a forma. Outro aspecto que constrói a visualidade característica desses objetos é a apropriação de materiais industriais com certas especificidades no contexto moderno: por um lado a pedra, elemento rústico, significativo na composição do solo, que se apresenta organicamente como natura, por outro lado, o ferro sucateado, um objeto préfabricado de uso industrial revela-se como, metaforicamente, intervenção do homem sobre a natureza: a cultura. A partir desse enfoque, a obra de Jackson Ribeiro manifesta seu aspecto conceitual, ao lidar com a plasticidade dos objetos da composição e com o conflito natureza/cultura, ou seja, com formas apropriadas da natureza e transformadas pela cultura. A partir dessa leitura preliminar, entendemos que a criação/expressão de Ribeiro ativa novas experiências sensíveis: sentir com os olhos a textura da sucata de ferro e o peso da pedra de mármore, ou ainda tatear formas geométricas e construir figuras vivas, são experiências sensíveis reveladas pela visualidade da criação. A experiência sensível do observador se relaciona internamente com a reflexão que ele faz a partir da criação do artista, consequentemente, compreendemos que a experiência sensível com a obra de arte também motiva uma experiência de pensamento (CHAUÍ, 2002). Uma obra de arte convoca o sentir e o pensar. Deduzimos, portanto, diferentes sujeitos influenciando-se, criando conjuntamente, experimentando uma realidade a partir de relações intersubjetivas.

As relações intersubjetivas são fundamentais para entender a realidade que o observador percebeu, isso quer dizer que elas são os princípios racionais que justificam a existência dessa realidade. Essas relações são sensíveis, perceptíveis, mas não se esgotam na exterioridade dos sentidos: elas potencializam uma interioridade que é pensamento. Assim, acreditamos que a experiência de pensamento está entrelaçada com a experiência sensível. 
Mas o que é essa realidade sentida, percebida? Ela é uma percepção do mundo, um olhar sobre os homens e as relações que eles estabelecem entre si e a natureza. Ela é crítica e se orienta por questões sociológicas e fenomenológicas. Ela é a outra criação que falávamos inicialmente, ela é social e é sensível.

Nesse trabalho, pretendemos responder duas indagações que se orientam por essas relações entre a sociologia e a fenomenologia, e desejam cercar o fenômeno que percebemos: 1) O que é essa relação entre o social e o sensível que ganha visualidade na obra de Jackson Ribeiro? 2) Como são construídas e como se dinamizam as relações intersubjetivas artista/obra de arte/observador, ou melhor, Jackson Ribeiro/social-sensível/pesquisador? Para responder essas questões propomos um recorte histórico que objetiva abranger a produção do artista entre 1959 e 1984. Assim, temos a intenção de situar a expressão artística de Ribeiro dentro do período em que ele estabelece uma comunicação da sua obra através de exposições e salões de arte. Dessa maneira buscamos assinalar quais elementos da sua produção possibilitam a visualidade da relação entre o social e o sensível.

Organizamos a dissertação em duas sessões, além da introdução e das considerações finais. Realizamos uma pesquisa que contempla a área de concentração do nosso programa de pós-graduação, Estética e História da Arte. Nesse sentido, a partir dos estudos dentro da nossa linha de pesquisa em Metodologia e Epistemologia de Pesquisa, orientados pela Profa. Dra. Carmen Sylvia Guimarães Aranha, elaboramos um estudo da obra do artista, com levantamento historiográfico, tratamento arquivista e documental, para situar a obra historicamente. Definimos esses procedimentos como uma etapa preliminar ao trabalho de pesquisa, em seguida empreendemos uma reflexão filosófica do objeto de estudo. Sendo, portanto, uma pesquisa com enfoque em Estética e História da Arte, essa pesquisa revela um duplo comprometimento: filosoficamente, compartilhamos com pensamentos essencialistas que compreendem a natureza da arte existente independentemente do tempo e lugar; historicamente, estamos comprometidos com a existência do estatuto do objeto artístico, ou seja, o que faz algo ser uma obra de arte em determinado tempo da história. Nesse sentido, entendemos que a história, tal como ela nos é apresentada, coloca a questão da essência da arte diante de traduções da cultura. Isso quer dizer, que as condições necessárias e suficientes para existir a arte estão também relacionadas aos discursos e instituições fundados nas relações sociais. Com esse duplo comprometimento, acreditamos que a leitura da obra de Ribeiro é indispensável para entender sua expressividade, contudo, não podemos isentá-la do contexto histórico da sua produção e das ideias e condições que fundamentam o conceito de arte. Ou seja, desde a observação, desejou-se entender como os laços culturais desenvolvem 
uma trama interior a obra, a partir da experiência do artista, e que ganham expressividade na criação artística. $\mathrm{O}$ ato criador transcorre uma história particular, para dialogar com uma universalidade artística enquanto expressão.

$\mathrm{Na}$ primeira sessão, situaremos historicamente a obra do artista, mapeando sua produção por períodos e relacionando-a com as fases poéticas do artista. Nosso objetivo é fornecer à História da Arte informações sobre a vida e a obra do artista, posto que essas informações estão dispersas em livros de artistas, biografias, arquivos museológicos e que nunca foram sistematizadas anteriormente. Simultaneamente, destacaremos e analisaremos algumas obras, com a intenção de ponderar nossa primeira questão: $O$ que é a realidade que percebemos e que tratamos como a relação do social e o sensível, que ganha visualidade através da obra de Jackson Ribeiro? Para auxiliar nossa reflexão, realizamos um estudo dos arquivos do artista em instituições museológicas, buscando pistas sobre a recepção da sua obra e o contexto das transformações da sua produção. Tal procedimento sistematizou nosso olhar sobre a produção do artista, e objetivou tão somente visualizar as fases de um processo poético, sem qualquer pretensão de encerrar sua produção em classificações determinantes. Por vezes, a organização das obras por fases poéticas segue uma orientação cronológica, porém evitamos seguir essa orientação strito sensu, tendo em vista que o artista revisava constantemente seu processo poético e suas soluções plásticas foram ora revisitadas ora abandonadas. Para situar o período da História da Arte no qual se insere a obra de Jackson Ribeiro, descreveremos alguns apontamentos dos críticos de arte, entendendo-os dentro da sua historicidade, e, portanto, considerando-os enquanto leituras de fases do processo poético do artista. O procedimento que adotamos nesse caso foi o levantamento bibliográfico e documental (textos de jornais, catálogos, panfletos) e entrevistas não-padronizadas quando julgamos necessário ${ }^{2}$. Também foi considerado o recorte de estudo que indica o período entre a primeira exposição da obra do artista (1959) e a exposição da última criação (1984), considerando que antes da aparição da sua obra no circuito de arte e posterior à apresentação da sua última criação existem diversas expressões que serão tratadas de maneira tangencial nesse trabalho.

Na segunda sessão, empreenderemos uma análise no campo da nossa linha de pesquisa em metodologia e epistemologia. Orientaremos uma discussão que objetiva dar subsídios à nossa leitura sobre o social e o sensível, a partir das relações de intersubjetividade. Organizaremos em capítulos específicos duas questões que estão concatenadas: Como são

\footnotetext{
${ }^{2}$ Entrevista não padronizada segue um roteiro, alterado a partir de novas informações coletadas durante a entrevista.
} 
construídas e como se dinamizam as relações intersubjetivas artista/criação/observador? Desejamos analisar a natureza das relações existentes entre a subjetividade de Jackson Ribeiro e sua expressão artística, a intencionalidade da sua expressão que motiva uma nova criação do pesquisador. Essa nova criação, que acreditamos ser uma experiência de pensamento do pesquisador, é a realidade que percebemos a partir dessas relações intersubjetivas.

Por último, nesta introdução, deve-se justificar que optamos por apresentar no decorrer do texto algumas imagens alusivas, embora tenhamos reunido toda pesquisa iconográfica como anexo da dissertação.

\section{O PROCESSO POÉTICO DE FERNANDO JACKSON RIBEIRO}

A primeira parte dessa pesquisa pretende situar a obra de Jackson Ribeiro dentro da História da Arte. Com isso, pretendemos compreender como sua obra repercutiu no Brasil e no exterior. Trabalhamos com a hipótese que a poética de Jackson Ribeiro se configura, historicamente e esteticamente, como uma vertente transitória entre o que se convencionou tratar como arte moderna e arte contemporânea.

Reconstruir textualmente a trajetória de Jackson Ribeiro, a partir da criação das esculturas/objetos conhecidas como "elementares" até a criação das Decorrências Modulares, orienta-se no sentido de evidenciar um trabalho de experimentação particular de um artista. A questão inerente do artista, que motivou sua expressão no contexto da vanguarda brasileira dos anos 1960, protagonizou um programa crítico, excepcional no Brasil. O processo experimental de Jackson Ribeiro dialogou rapidamente com diversas propostas que surgiram no final dos anos 1950, embora sua criação tivesse uma ligação tanto com o projeto moderno quanto com as questões da arte contemporânea. 
O registro de Jackson Ribeiro na arte começou periférico, com o ofício da molduraria, nela o artista lidava com a questão da moldura como estrutura que não poderia superar a pintura e que deveria manter a neutralidade. Após uma breve experiência na pintura, Ribeiro descobre a potencialidade da cor/forma relacionada com a materialidade da sucata de ferro e da pedra bruta, engajando-se na criação experimental através da assemblage. O artista experimenta o diálogo da sua criação com corpos cênicos, estabelecendo uma ponte particular entre as formas dos objetos e o corpo humano, orientando-se no caminho de uma espécie de performance. Liberdade para ações, experiências com observadores de contextos socioeconômicos diferentes, a obra de Ribeiro foi popular porque atingiu a favela carioca, o circuito oficial e elitista de arte no Brasil e no exterior, e nos dias de hoje ainda protagoniza uma polêmica política clássica entre arte e discurso religioso.

A crítica que Jackson Ribeiro colocou ao mercado de arte, tendo a galeria como intermédio, ganhou sentido na criação de um supermercado de artes como uma espécie de ato público similar a um happening, sendo que com uma duração bem superior que a um simples ato: contestar o mercado elitista com uma ação popular - entre, pegue sua obra, negocie direto com o artista e leve-a consigo. O auto-exílio, que o artista estabeleceu com o circuito oficial, lhe relegou figurar na História da Arte como coadjuvante de outros artistas ou, simplesmente, compor a memória de artistas que relatam um período em que se acreditava em Jackson Ribeiro como um dos expoentes da sua geração: fez dele um artista de artistas.

Igualmente importantes foram as incursões de Jackson Ribeiro no campo do design e da integração do espaço arquitetônico e urbanístico. A descoberta das decorrências modulares e a preparação de um jogo construtivo experimental motivaram relações entre a arte e design. Ao mesmo tempo em que suas criações também foram pensadas para espaços públicos e de convívio social urbano.

Por fim, entendemos que essa primeira parte da dissertação, com ênfase em História da Arte, só foi possível a partir de combinações entre a historiografia do processo poético, a historicidade das obras e o estudo de arquivo do artista, constituindo uma metodologia fundamental para ancorar a revisão crítica da trajetória do artista e do seu contexto.

\subsection{Os acervos museológicos e os caminhos da construção da linguagem}

Até o final dessa pesquisa foram localizadas treze obras de Fernando Jackson Ribeiro em sete acervos museológicos no Brasil. Os acervos museológicos que salvaguardam as obras 
do artista são o Museu de Arte Contemporânea da Universidade de São Paulo (MAC-USP), Museu de Arte Contemporânea do Paraná (MAC PR), Museu de Arte Moderna de São Paulo (MAM-SP), Museu de Arte Moderna do Rio de Janeiro (MAM Rio) e Museu Nacional de Belas Artes (MNBA), no Rio de Janeiro, Fundação José e Paulina Nemirovsky, em São Paulo, e o Museu Casa de José Américo, em João Pessoa. Trataremos de construir um panorama das fases poéticas do artista e o histórico do ingresso das obras nas respectivas coleções museológicas. A maioria das obras foi admitida por esses acervos em virtude de sua exposição no circuito de arte. No entanto, para além da sua importância para o circuito de arte, essas obras nos orientam a compreender os caminhos da construção da linguagem do artista e que envolvem as reflexões que desenvolvemos durante a pesquisa. A experiência com as obras fundamentam nossa metodologia, que busca entender como são construídas e como se dinamizam as relações subjetivas artista/obra-de-arte/observador, em nosso caso Jackson Ribeiro/social-sensível/pesquisador.

Há duas obras que figuram a mesma fase poética de Ribeiro e que pertencem a dois acervos museológicos diferentes. A obra Elementar n.5 (Fig. 1, p. 22) é um objeto que foi incorporado ao acervo do Museu de Arte Contemporânea da Universidade de São Paulo (MAC USP) através da doação feita pelo Museu de Arte Moderna de São Paulo (MAM SP). Cronologicamente, Elementar $n .5$ foi a primeira obra de Jackson Ribeiro a ser adquirida por um museu. A obra Elementar 4 (Fig. 2, p. 22) foi adquirida pelo colecionador José Nemirovsky e atualmente faz parte da coleção da Fundação José e Paulina Nemirovsky.

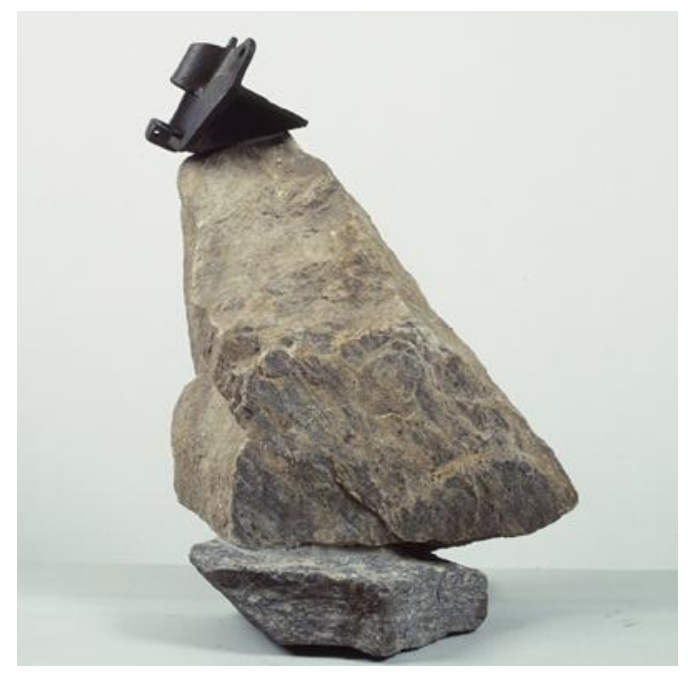

Figura 1 - RIBEIRO, Jackson. Elementar 5, 1960 , pedra e ferro, $59,6 \times 49 \times 31,7 \mathrm{~cm}$. Acervo Museu de Arte Contemporânea da Universidade de São Paulo. Foto: Arquivo

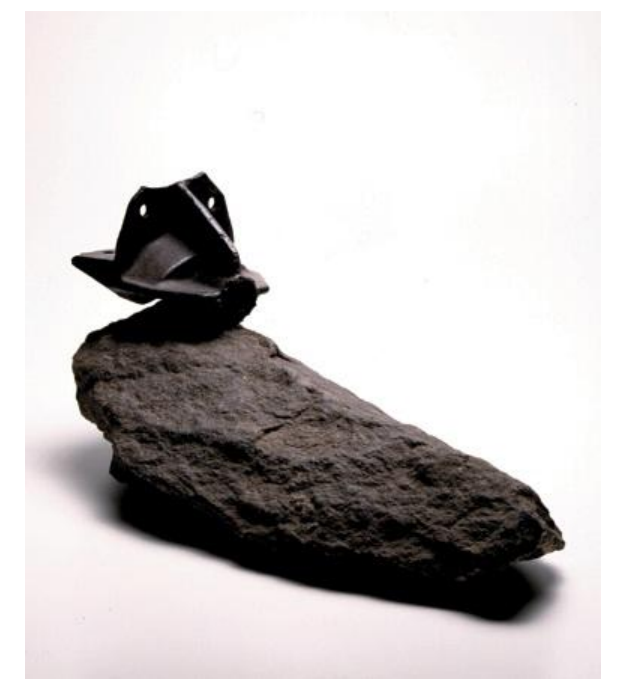

Figura 2 - RIBEIRO, Jackson. Elementar 4, 1961. Ferro e pedra. 26 × 51 × $25 \mathrm{~cm}$. Acervo da Fundação José e Paulina Nemirovsky. Foto: acervo Fundação José e Paulina 
sses objetos representam uma fase que entendemos como a "poética dos elementares" (SOARES, 2010b). Nela, o artista constrói sua linguagem a partir da conjunção dos elementos pedra e ferro. Há duas relações importantes para se compreender o caminho dessa construção da linguagem de Jackson Ribeiro:

a) uma relação afetiva que o artista tinha com sua experiência no trabalho, tanto no ofício de extração de minérios quanto no ofício de moldureiro;

b) a outra relação está no diálogo de Jackson Ribeiro com outros artistas contemporâneos que se apropriaram de formas dadas, objetos encontrados ou préindustrializados para a construção da sua linguagem.

Nos objetos Elementar $n .5$ e Elementar 4, o artista reconhece a forma dos elementos de composição, a pedra e o ferro, e a partir da conjunção dessas formas surgem as figuras expressionistas nomeadas de "elementares". Embora sejamos induzidos a uma leitura formal da obra, cabe-nos informar os dados da experiência que o artista tinha com a pedra e o ferro, antes mesmo do surgimento dos "elementares". Ribeiro lidou com rochas e pedras durante o ofício de extração de minérios nos anos 1950, no Estado de Mato Grosso. Cuiabá está localizada em uma paisagem de serrado, entre a Chapada dos Guimarães e o Pantanal, o que favoreceu o garimpo como economia extrativista. O trabalho de Jackson Ribeiro com a extração de minérios lhe faz entender as qualidades das pedras e suas formas dadas, cuja composição cristalizada revela profundidades, pesos, volumes, cores, texturas, uma educação plástica e visual que deixou marcas na experiência do artista. Quando chegou ao Rio de Janeiro, no final dos anos 1950, Ribeiro precisou construir máquinas para lidar com a molduraria e nesse ofício começa a lidar com o ferro. A busca por peças, engrenagens, parafusos passava tanto por uma necessidade funcional para a construção de máquinas e objetos, quanto pelo reconhecimento formal dos objetos pré-industrializados: curvas, linhas, novamente profundidade, peso e volume. Ou seja, o caminho percorrido por Ribeiro para a construção de uma linguagem com a pedra e o ferro passou pela experiência do trabalho artesanal e cotidiano com esses elementos e a compreensão das suas qualidades estéticas.

O caminho percorrido por Jackson Ribeiro para a construção da linguagem da "poética dos elementares" passou por um olhar sensível para as formas dadas e pelo reconhecimento de um conteúdo semântico em determinados elementos. Isso quer dizer que a conjunção da pedra bruta, um elemento da natureza "crua", dada, com o ferro sucateado, usado pelo homem e descartado, comunicam uma realidade interna que é vivida pelo artista, com uma realidade 
social, ambiental, sensível que é vivida pelos observadores da obra. Os objetos Elementar $n .5$ e Elementar 4 são introduções de um processo poético marcado pela construção de uma linguagem que comunica algo invisível: uma realidade compartilhada pelo artista e pelos observadores da obra.

A construção dessa linguagem não estava isolada, sem comunicação ou diálogo com outras linguagens. O ofício da molduraria, como veremos no próximo capítulo, foi um canal de entrada de Jackson Ribeiro no circuito carioca das artes visuais. No Brasil, Jackson Ribeiro estava situado no contexto em que o movimento da arte neoconcreta estava cada vez mais efervescente no cenário carioca dos anos 1960. A arte neoconcreta apontava algumas questões que deixaram pistas para se entender os desdobramentos da arte nos anos 1960. O que acontecia naquele período era a eminência de um debate contra o discurso de arte hegemônico, que destacava sua vertente do concretismo no Brasil. Aquela geração experimentava o que hoje se convenciona tratar, seguindo a crença nessa ou naquela teoria, a distinção entre o que é moderno, pós-moderno e contemporâneo. $\mathrm{O}$ debate neoconccreto foi uma tomada de postura diante da arte não-figurativa "geométrica" e da arte concreta. Todavia não seria prudente afirmar, stricto sensu, que Jackson Ribeiro era um artista neoconcreto, mesmo porque ele não foi um dos artistas signatários do manifesto de 1959. Mas não podemos descartar a postura de uma arte neofigurativa dos seus trabalhos, e como essa postura foi compreendida por um contexto marcado pelo debate do neoconcretismo. Circulavam no seu ateliê os artistas Lygia Clark, Lygia Pape, Amilcar de Castro e Hélio Oiticica, esses dois últimos também foram seus parceiros em criações.

A $1^{\text {a }}$ Exposição Nacional Neoconcreta já pontuava críticas à narrativa modernista, cuja argumentação tinha como concepção que "a arte para além do limite ou não faz parte da varredura da história ou é uma reversão a alguma forma antiga de arte” (DANTO, 2006, p. 11). A crítica de arte nos anos 1960 tentava distinguir um grupo de artistas que aos poucos ganhava uma autonomia do pensamento modernista. O que se começava a produzir era uma sorte de arte não mais restrita a uma narrativa greemberguiana, era algo diferente e conflituoso, algo que não tinha uma nomenclatura oficial ou era defendida por todos os seus envolvidos, sua categorização já não se permitia dentro daquela "nova" estrutura. No final dos anos 1950 e início dos anos 1960 havia uma produção de arte que notavelmente se aproximava do concretismo, mas a cada nova exposição mais e mais artistas apresentavam diferentes olhares sobre a arte. As duas mais importantes mostras brasileiras, a Bienal de São Paulo e o Salão de Arte Moderna do Rio de Janeiro, revelavam pistas sobre as transformações que marcaram a geração de 1960. No início dos anos 1960, o debate crítico 
entre concretos e neoconcretos era mais evidente, seguindo a $1^{\text {a }}$ Exposição Nacional Neoconcreta no Museu de Arte Moderna do Rio de Janeiro (MAM Rio), em 1959, o $8^{\circ}$ Salão Nacional de Arte Moderna selecionou alguns trabalhos de artistas neoconcretos. Nesse mesmo ano, Jackson Ribeiro participou do Salão de Arte Moderna do MAM Rio, na sua primeira exposição, apresentando um cristo de ferro. Na edição do Salão de Arte Moderna do ano seguinte, Ribeiro apresenta seus objetos de pedra e ferro.

Nesse período, a obra de Jackson Ribeiro já era conhecida pelos críticos de arte Teixeira Leite, Mário Pedrosa e Pierre Restany. Espontaneidade enquanto experimentalismo, o trabalho de Jackson Ribeiro despertava à crítica da época um dos elementos que compunha uma estrutura de pensamento em transformação, onde poderia se perceber outras formas de diálogo do homem com a natureza. Jackson Ribeiro se apropriava de alguns conceitos que transcendiam o construtivismo da arte concreta, desde a elaboração dos totens de pedra e sucata às formas de um figurativismo espontâneo. Todavia a crítica de arte da época realizava, em geral, um sobrevôo distante da obra de Jackson Ribeiro. Os críticos percebiam as visualidades da obra do artista, mas pouco se detinham a inquirir filosoficamente a respeito da realidade interna da obra, que relacionava a condição social na qual a humanidade se encontrava com a sensibilidade do artista em dar visualidade poética e realizar uma crítica social. Tanto a crítica social presente na obra, quanto a sensibilidade do artista em tornar isso visível, são camadas de uma experiência que o observador tem quando está interagindo com a obra, isso quer dizer que a visualidade da obra é uma experiência intersubjetiva artista/obrade-arte/observador. Naquele contexto, alguns críticos se atentaram para a retomada do readymade com outro objetivo, presente nas criações de Jackson Ribeiro: se a revolucionária criação de Marcel Duchamp age no sentido de uma atitude antiestética (ZANINI, 1971, p.146) na escolha de um objeto qualquer, por outro lado ela "ganha valor poético pelo ato da seleção e da apresentação" (ZANINI, 1971, p.150-151); a seleção dos objetos por Jackson Ribeiro acontece a partir dos elementos que lhe atraem fisionomicamente, ele não parte da idéia de "elementos-coisas" (OITICICA, 1964). Não por acaso, a transfiguração dos elementos revela no observador um sentido imaginativo que resulta na visualização de figuras. Nesse sentido, a atitude de Jackson Ribeiro consistia em explorar a idéia de readymade de uma forma estética, tratando os elementos plásticos de maneira formal. Essa postura era compreendida dentro de um contexto da arte no Brasil que integrava outros artistas que lançavam mão de uma expressão figurativa, com a apropriação de meios não convencionais para o modernismo. O que se convencionou chamar de "nova figuração" compreendia diversas construções de linguagens, reunindo técnicas sobre um mesmo suporte, desafiando 
construir linguagens que quanto mais longe estavam das abstrações geométricas mais próximas estavam de uma figuração defendida por aquela geração de artistas dos anos 1960 . Nas obras Elementar $n .5$ e Elementar 4 Jackson Ribeiro justapõe a pedra e o ferro com pouca ou quase nenhuma transformação dos materiais; nesse sentido, sua preocupação revela-se em situar os materiais enquanto forma plástica e materialidade, elementos compositivos esses que se somam e dinamizam a linguagem escultórica, "como se quisesse arrancar da pedra um rosto, imagens arcaicas, perturbadoras na sua força e no seu silêncio" (MORAIS, 1984). Outro aspecto que constrói a visualidade característica dessas obras é a apropriação de materiais com certas especificidades no contexto moderno experimentado com a industrialização: por um lado a pedra, elemento rústico, significativo na composição do solo, que se apresenta organicamente como natura, por outro lado, o ferro sucateado, um objeto pré-fabricado de uso industrial revela-se como, metaforicamente, intervenção do homem sobre a natureza: a cultura. A partir desse enfoque, a obra de Jackson Ribeiro manifesta seu aspecto conceitual, ao lidar com a plasticidade dos objetos da composição e com o conflito natureza/cultura, ou seja, com formas apropriadas da natureza e transformadas pela cultura.

A fase dos elementares desencadeia novos estudos de Jackson Ribeiro com os objetos. Nesse momento, as expressões escultóricas já levantavam questionamentos a respeito do trabalho do escultor. $\mathrm{O}$ artista percebe possibilidades de visualidade a partir da composição apenas com o ferro pré-industrializado, imagens construídas tal como totens de sucata. Um caminho norteado por questões da escultura, volumes e massas, concentradas no espaço, desenhando figuras mórficas, criando visualidades imaginativas, expressivas e por vezes fantasmagóricas. Dessa fase poética, encontramos as seguintes obras:

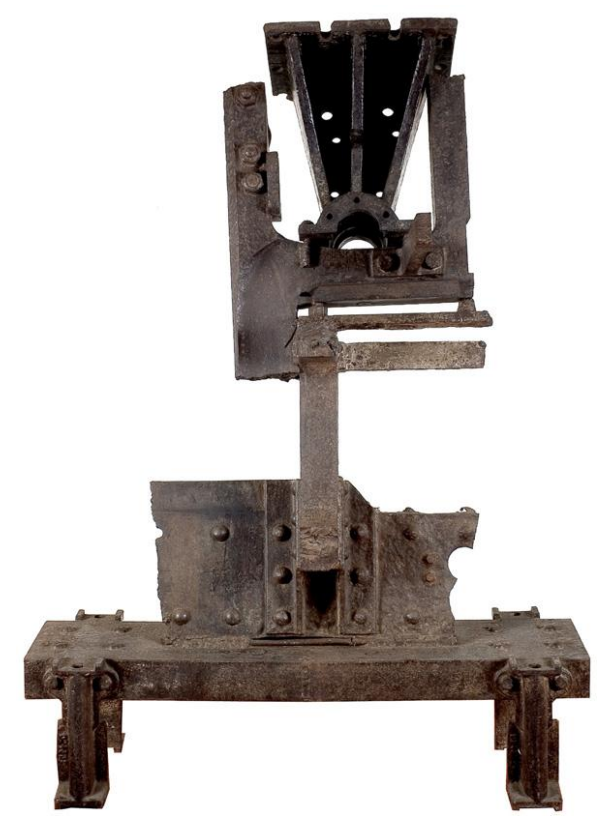


Figura 3 - RIBEIRO, Jackson. Fausto, 1964, ferro, 165 x 120 x 89 cm. Acervo Museu Nacional de Belas Artes. Foto: Acervo do Museu Nacional de Belas Artes

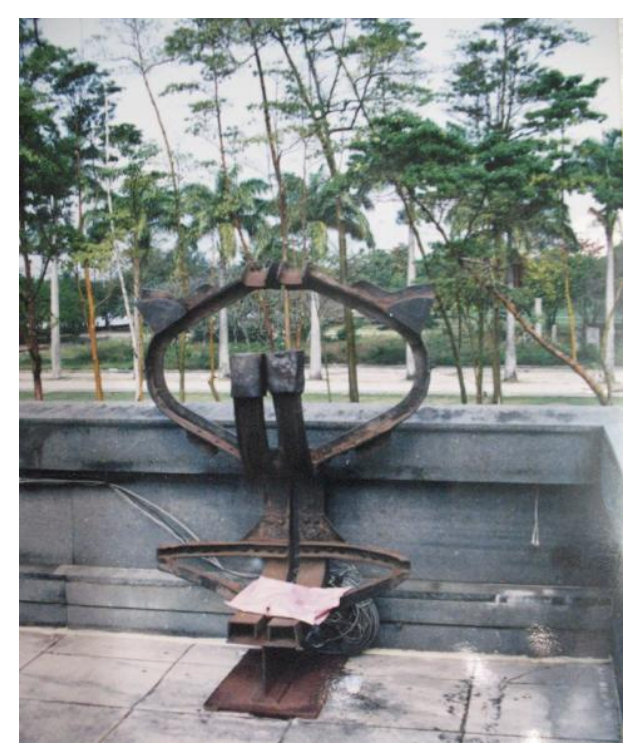

Figura 4 - RIBEIRO, Jackson. Construção XIV, 1967, Alumínio. Acervo Museu de Arte Moderna do Rio de Janeiro. Foto: Museu de Arte Moderna do Rio de Janeiro.

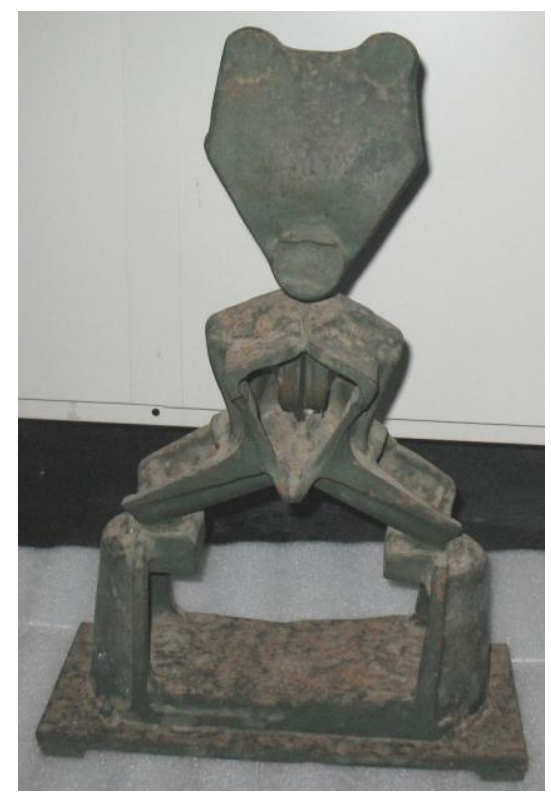

Figura 5 - RIBEIRO, Jackson. Sem título, (?), Ferro. Acervo Museu de Arte Moderna do Rio de Janeiro. Foto: Museu de Arte Moderna do Rio de Janeiro. 


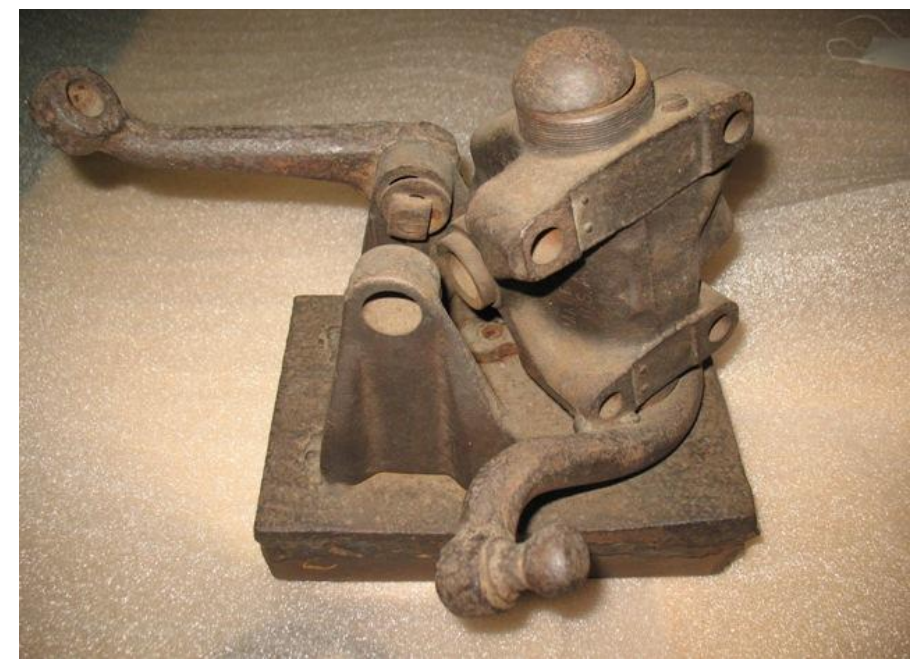

Figura 6 - RIBEIRO, Jackson. Sem título, (?), Ferro. Acervo Museu de Arte Moderna do Rio de Janeiro. Foto: Museu de Arte Moderna do Rio de Janeiro.

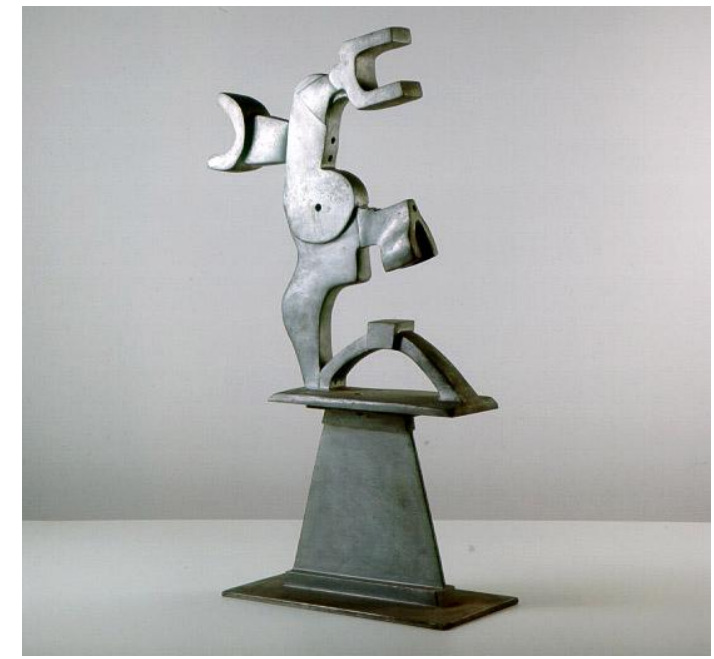

Figura 7 - RIBEIRO, Jackson. Construção 3, 1972, Alumínio. Acervo Museu de Arte Moderna de São Paulo. Foto: Museu de Arte Moderna de São Paulo. 


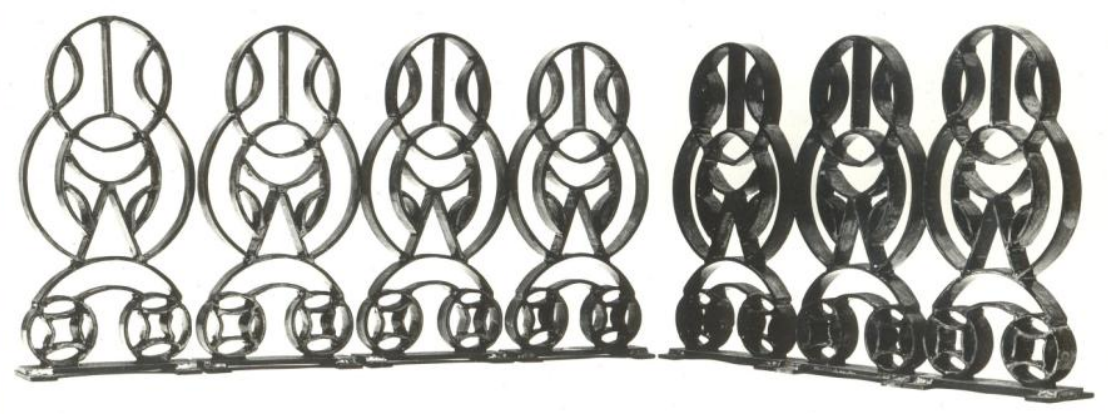

Figura 8 - RIBEIRO, Jackson. Sem título múltiplo II, [1972], ferro. Museu Casa de José Américo. Foto: CENTRO Empresarial Rio. FOTO: CENTRO Empresarial Rio Catálogo da exposição Jackson Ribeiro Os Elementares: 29 de fevereiro a 7 de abril de 1984. Rio de Janeiro: Centro Empresarial Rio, 1984.

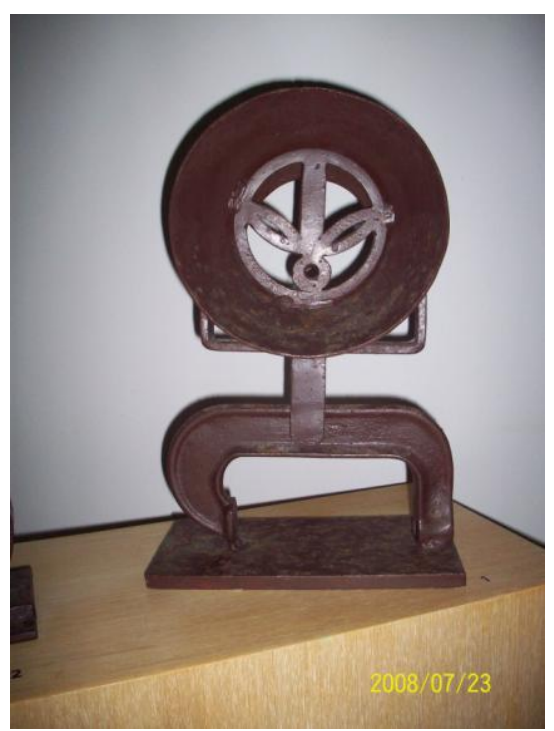

Figura 9 - RIBEIRO, Jackson. Sem título. [1972], ferro. Museu Casa de José Américo. Foto: Acervo Museu Casa de José Américo 
Além dos trabalhos citados, existe a obra pública, Porteiro do Inferno, criada em 1965 e localizada em João Pessoa, também integra a fase poética dos totens de sucata. Contudo, preferimos fazer uma leitura separada no capítulo 1.4, quando concluiremos essa sessão.

Os objetos dessa fase poética do artista revelam um caminho através da figuração cada vez mais expressionista. Sendo que a construção das imagens de Ribeiro, muito em virtude da linguagem com o ferro, tem também um apelo realista de revelar o material que se faz uso. Nesse sentido, o artista compõe figuras com objetos dados pela realidade e os transforma em imagens com novos significados, despertando sentimentos e emoções. A intensidade com a qual os objetos se comunicavam com seus observadores revela um fenômeno de identificação com as obras. Se por um lado o artista buscou uma nomeação abstrata, capaz de orientar uma leitura da obra por suas características formais, por outro lado a obra motivava uma identificação a partir dos seus observadores que passavam a nomear os objetos, independente da titulação proposta pelo artista. Esse fenômeno foi expressivo no caso da obra Fausto (Fig. 3, p. 27). Em 1964, Jackson Ribeiro surpreendeu o Salão de Arte Moderna do Rio de Janeiro quando expõs um objeto que foi alegoria de uma escola de samba. Naquele ano, Jackson Ribeiro, Amilcar de castro e Hélio Oiticica trabalharam na alegoria do enredo "Uma história de preto velho", da escola de samba Estação Primeira de Mangueira. A identificação com dois objetos de Ribeiro motivou sua nomeação, proposta pelas pessoas da própria comunidade: Fausto e Faustina. Embora não tenhamos certeza se o nome faz alusão ao personagem de Goeth, podemos inquirir que a relação com objeto remete a uma identificação afetiva a ponto de provocar no observador a participação ativa na construção da obra.

O que podemos indicar como características marcantes dessa fase poética é a síntese formal que o artista empreende com os objetos de ferro. Um objeto escolhido pelo artista é o motivo central, a provocação de um desenho que o observador é convidado a desvelar. Um objeto leva a outro objeto, justapondo as formas, construindo uma composição vertical tal como um totem. Compreendemos a obra Construção XIV (Fig. 4, p. 27) dentro dessa fase poética, embora saibamos que sua elaboração aconteceu posterior ao período que Jackson Ribeiro viveu na Espanha e na França, durante um programa de residência artística (19651967). Esse período, por exemplo, a França estava marcada pelas provocações do movimento de artistas conhecidos como novos realistas. E percebemos um novo encaminhamento sobre a disposição das formas nas construções de Jackson Ribeiro. É quando começam a surgir construções de sucata de ferro bilaterais: se antes o objeto construído possibilitava o observador visualizar mais de uma imagem para cada mudança de ângulo de observação, novos objetos surgem como soluções mórficas que saltavam ao olhar por dois lados, como se 
o objeto tivesse uma frente e um verso, nessa fase destacamos o aspecto de uma geometrização bilateral. Exemplares dessa fase compõem a coleção do Museu de Arte Moderna de São Paulo e o Museu Casa de José Américo. A obra que faz parte da coleção do MAM SP é o objeto Construção n.3 (Fig. 7, p. 29). A obra foi doada pelo artista em virtude da participação da mostra Panorama de Arte Atual Brasileira, em 1972. Desde que foi instituída uma fundação em 1962 para gestão da Bienal de Arte de São Paulo, a mostra passou a ter uma comissão própria e deixou de ser vinculada ao museu. O MAM SP passava por uma fase complicada da sua história, pois tinha um registro público de museu, mas havia sofrido uma defasagem em seu acervo que foi doado para fundação do Museu de Arte Contemporânea da USP, em 1962. Por esse motivo, o objeto Elementar 5 (Fig. 1, p. 22) faz parte da coleção do MAC USP. Em 1969, com o objetivo de mapear a produção brasileira, O MAM SP realiza o primeiro Panorama de Arte Atual Brasileira, que mais tarde passaria a se chamar Panorama da Arte Brasileira. A exposição foi pensada como estratégia de renovação do acervo do Museu com obras recentes - fosse por meio de premiações financiadas por patrocinadores ou pessoas físicas, fosse através de doações realizadas por artistas participantes. Além de se atualizar sobre a produção nacional, o Panorama marcou um processo de restituição de um acervo para o museu.

As obras do Museu Casa de José Américo são objetos exemplares da fase que o artista empreendeu uma geometrização bilateral em suas criações. Portanto, são objetos que fazem parte de uma produção realizada entre 1965 e 1978. O ano de criação dos objetos é indeterminado pela instituição. Consta nos arquivos desse museu que as obras pertenceram ao escritor José Américo de Almeida e foram doadas pela família para formação do acervo do museu. Contudo, não há indicação do ano de aquisição das obras pelo antigo proprietário. Seguindo as pistas dos arquivos museológicos, sobretudo no MAC USP e MAC PR, identificamos que uma das obras de José Américo trata-se de um objeto múltiplo, de um número indeterminado de exemplares, assim como o cristo de ferro de Ribeiro. Orientamos a datação desse objeto para 1972, trataremos aqui como sem título múltiplo II (Fig. 8, p.29). Há uma fotografia de matéria de jornal que apresenta uma das obras do Museu Casa de José Américo ao lado da obra Construção n.3 (Fig. 7, p. 29). Embora o jornal seja 1978, a documentação do acervo do MAM SP informa que sua obra não foi exposta nem teve saída do acervo depois da mostra Panorama de Arte Atual Brasileira, 1972. Deduzimos, portanto, que a jornalista usou uma imagem ilustrativa, sem compromisso com sua data original, já que a obra do MAM SP é um exemplar único e cuja salvaguarda é controlada pela instituição. A outra obra é uma construção de Jackson Ribeiro, cujo caráter figurativo se apresenta na 
disposição que cada peça ganha no contexto escultórico. As duas obras foram adquiridas pelo proprietário na mesma época, e não constam informações ou dados fotográficos delas nos arquivos do artista, portanto, podemos inquirir que as conclusões de datação do múltiplo servem como parâmetros para a datação do segundo objeto.

A descoberta do jogo, Decorrências Modulares (Fig. 10, p. 33), foi o ápice do processo poético de Fernando Jackson Ribeiro e se deflagra como a terceira fase. Em 1979, o artista apresenta aos amigos Lygia Pape e Hélio Oiticica o conceito da sua criação. Um jogo com módulos fabricados pelo artista, disponíveis à criação do participante. Algumas soluções seriam propostas por Ribeiro que fixaria o resultado sobre um plano bidimensional, criando telas em alto relevo, chamadas de Elementares ou D.M. O jogo é em si uma obra/projeto e pode ser desenvolvida a partir dos dados e medidas elaborados pelo artista.

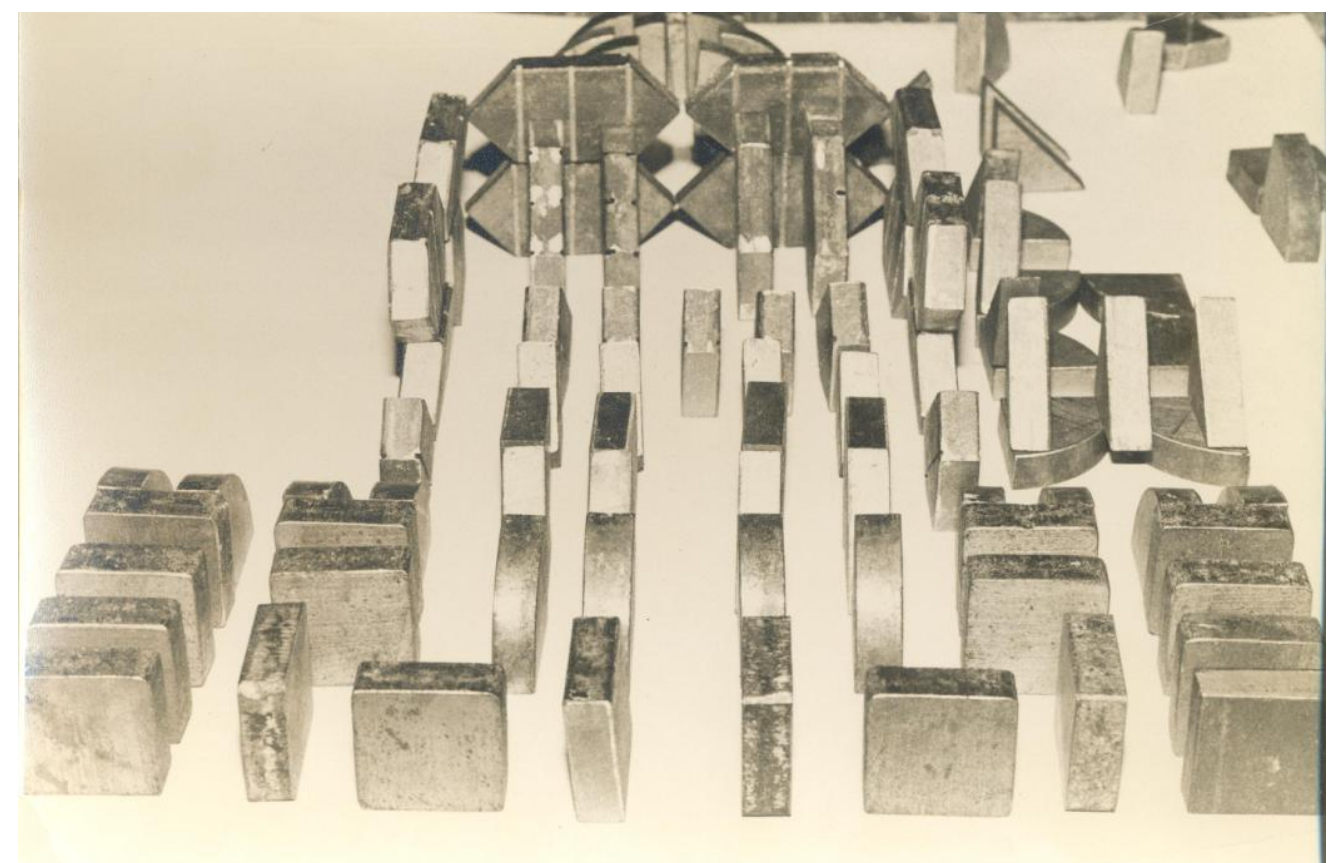

Figura 10 - RIBEIRO, Jackson. Decorrências Modulares, 1979. Obra/projeto. Ferro, alumínio e madeira. Acervo do Museu de Arte Contemporânea do Paraná. Foto: Arquivo do artista (Museu de Arte Contemporânea do Paraná).

Hélio Oiticica (1979) afirmou que as decorrências modulares partem do mesmo "princípio-totem” presente nas fases anteriores da poética de Jackson Ribeiro.

Jackson não era "fabricador de totens": o que regia seu processo criativo (e na verdade agora se floresce-desmembra nas D.M.) sempre foi o principio TOTEM que se liga diretamente à gênese das obras que criou: A descoberta tão rica das D.M. é ao mesmo tempo a fragmentação deste princípio-TOTEM e a sua apoteose: TOTEM - MÓDULO - DECORRÊNCIA MODULAR - MULTITOTEM. (OITICICA, 1979). 
O Museu de Arte Contemporânea do Paraná (MAC PR) tem duas série de serigrafias de Elementares ou D.M. em seu acervo. O MAC PR recebeu uma doação que constava documentos, objetos e fotografias do artista, que constitui o mais importante arquivo do artista em acervo museológico. Sem desenvolver um estudo sobre o próprio arquivo, o MAC PR catalogou peças originais da obra/projeto como matrizes das serigrafias que constam na sua coleção. $\mathrm{O}$ arquivo do artista neste museu é integrado por entrevistas, escritos e textos de críticos da obra, e indica que o jogo Decorrências Modulares (Fig. 10, p. 33) foi uma criação artística que origina as criações individuais e coletivas, tais como as duas serigrafias do acervo do MAC PR e uma pintura da coleção de Gilberto Chateaubriand, que está cedida em regime de comodato ao MAM Rio.

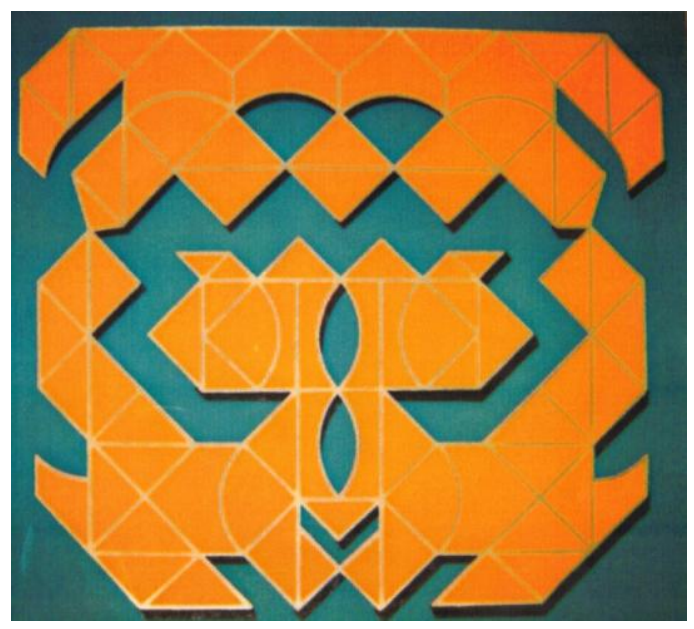




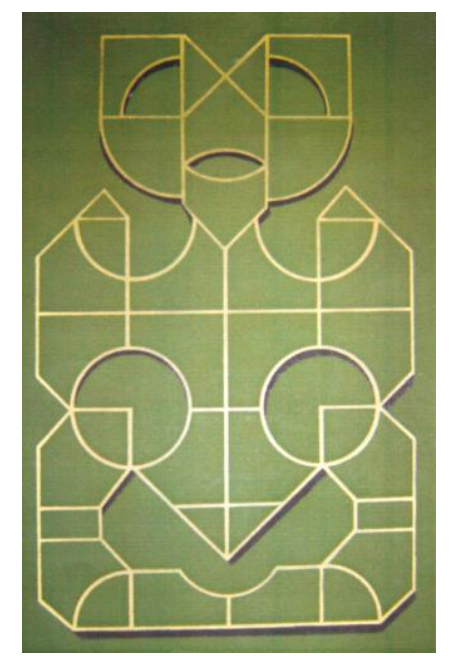

Figura 11 - RIBEIRO, Jackson. Sem título (Série A), 1990, Serigrafia sobre papel, 31 cópias, $(32,7 \times 23,6 \mathrm{~cm})$. Acervo do Museu de Arte Contemporânea do Paraná. Foto: acervo Museu de Arte Contemporânea do Paraná.

A obra/projeto foi a última criação de Jackson Ribeiro. O jogo das Decorrências Modulares (Fig. 10, p. 33) é infinito e tem diversos desdobramentos. Consegue transpor facilmente as disciplinas artísticas e realiza uma interface entre elas: pinturas/esculturas, objetos, designs, diversas formas de gravar, etc. Em 1984, foi realizada a primeira exposição dos Elementares ou DM de Jackson Ribeiro no Centro Empresarial Rio (RJ), as soluções das decorrências modulares afixadas sobre uma madeira plana, criando uma tela com composições de alto-relevo, onde o artista também pinta e destaca formas. Trataremos da obra/projeto Decorrências Modulares em um estudo particular apresentado a seguir.

\section{2 "A moldura tem que completar o quadro": o ofício de moldureiro-artista}

Fernando Jackson Ribeiro, natural da cidade de Teixeira, Paraíba, nasceu em 30 de outubro de 1928. Emergiu no circuito de arte no Rio de Janeiro, onde produziu e manteve ateliê nos anos 1960 e 1970. Aos nove anos de idade ele se mudou para Campina Grande, 
onde cursou o ensino básico, em seguida foi morar em João Pessoa, com os pais e os sete irmãos. Lá viveu até os 19 anos, quando migrou para Cuiabá para trabalhar no setor de extração mineral (SOUZA, 1978). Depois trabalhou dois anos na fiscalização das fronteiras do Brasil com a Bolívia e o Paraguai, em seguida mudou-se para Florianópolis onde conheceu sua primeira esposa. Voltou à Paraíba com sua esposa para trabalhar na propriedade agrária do pai, mas ficou viúvo e mudou-se para o Rio de Janeiro, em 1956 (SOUZA, 1978).

Aos 27 anos, no Rio de Janeiro, Fernando Jackson Ribeiro começou a trabalhar em uma molduraria, parceira da Galeria Dezon. Ribeiro relata, em uma entrevista à Maria Adélia Lopes (1988), que aprendeu molduraria com Oshiro Matsuda, quem ele afirmava ser discípulo de Tadashi Kaminagai, artista japonês que viveu no Brasil até meados nos anos 1950 e atuou no circuito de arte brasileiro como artista e moldureiro.

\footnotetext{
“O Kaminagai era um pintor importante. Mas acho que sua maior importância para as artes no Brasil passou despercebida, que era o processo de emolduração. Ele valorizou os quadros. É um equívoco da crítica colocar a moldura em terceiro plano. A moldura que Kaminagai fazia não existe mais hoje, só a comercial (...) Eu ainda faço, gosto de fazer e tenho o maior respeito à moldura. A prática de lidar com tinta levou-me a resolver uma boa tela". (LOPES, 1988, p. 8)
}

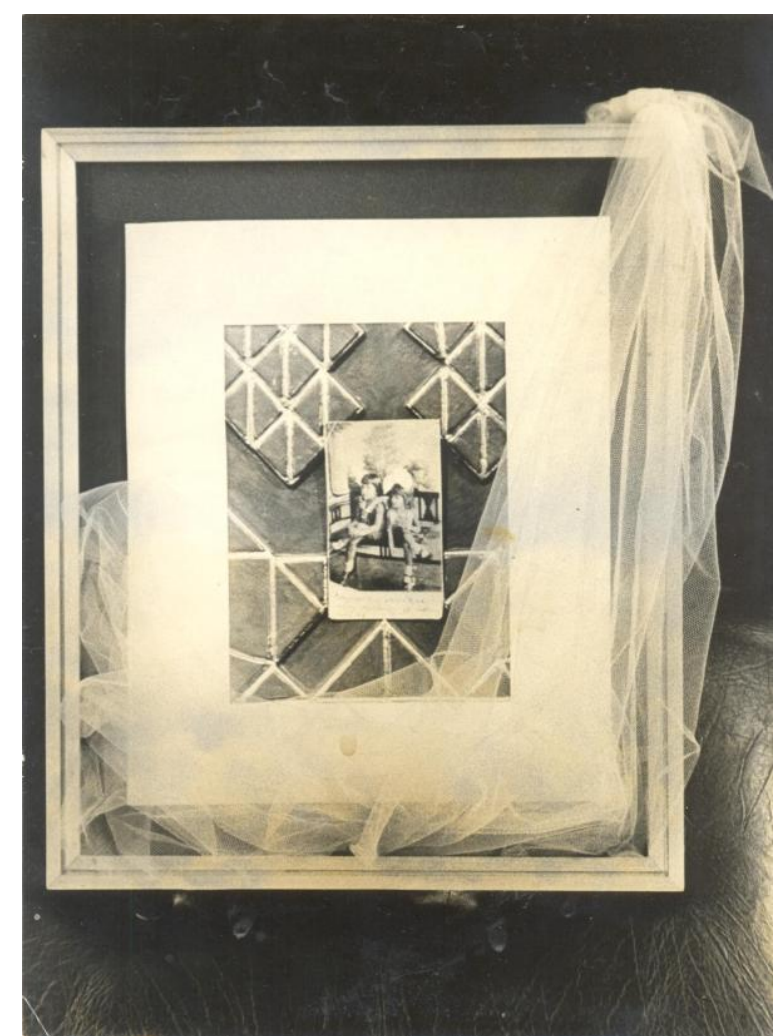

Figura 13 - Assemblage de Jackson Ribeiro. Tecido, moldura, Decorrências Modulares e fotografia. [1980?]. Foto: Arquivo do artista - Museu de Arte Contemporânea do Paraná. 
Como moldureiro, Jackson Ribeiro teve contato com a produção de artistas que circulavam no circuito de arte carioca, tais como Pancetti, Di Cavalcanti e Portinari (LISBONA, 1974). Consciente do seu ofício de moldureiro e respeitando a subjetividade de cada pintura com a qual lidava, Ribeiro foi introduzido às artes plásticas a partir da leitura das obras. Era a primeira etapa para a elaboração das molduras encomendadas: o moldureiro como mediador da obra de arte, diante do desafio de intervir em um objeto carregado de sentidos e qualidades ${ }^{3}$. Naquele momento, além dos museus e galerias, o circuito de arte colocava Ribeiro em um contato direto e exclusivo com as obras de arte. A molduraria sempre foi tratada por Jackson Ribeiro como seu primeiro ofício, nela germinava o esforço artesanal que se fez presente, posteriormente, nos caminhos da construção da linguagem do artista. Ribeiro prezava por criar a tinta mais adequada para cada moldura, assim como continuou a fazer para as pinturas, dos Elementares ou D.M. décadas mais tarde. A contínua experiência de moldar a madeira manteria latente uma linguagem própria para lidar com as Decorrências Modulares décadas mais tarde.

No final dos anos 1950, sugiram suas incursões na pintura. O artista constrói imagens matéricas, compostas de paisagens e figuras expressionistas experimentadas através de um tipo de encáustica, derretendo cera de vela sobre a tela e trabalhando-a com um maçarico. Nesse período, Ribeiro conjugava materiais e técnicas que criavam resultados que lhe davam indícios para experimentar outros materiais.

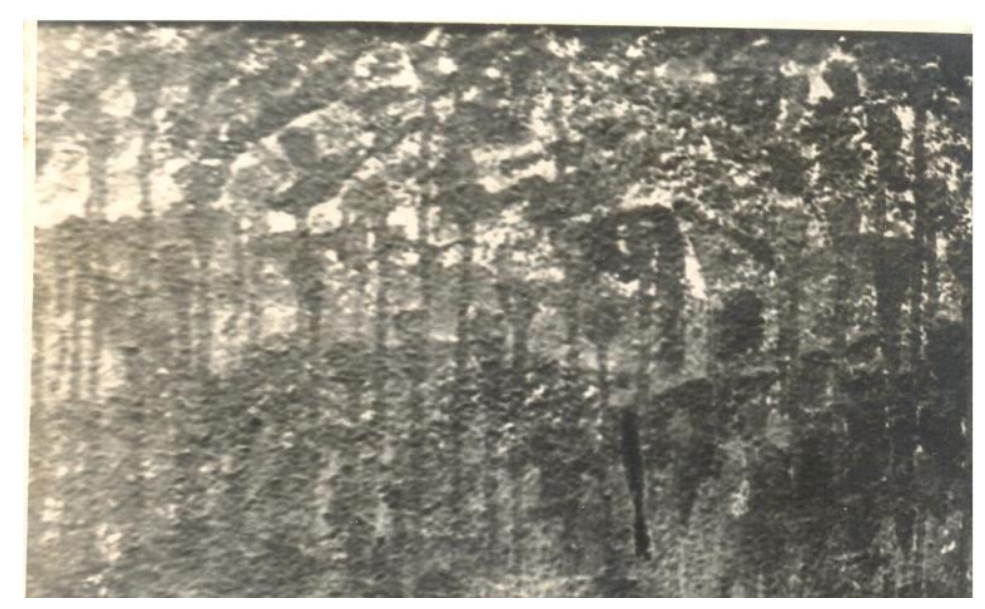

Figura 14 - Pintura de Jackson Ribeiro, 1958 [?]. Foto: Arquivo do artista - Museu de Arte Contemporânea do Paraná

\footnotetext{
${ }^{3}$ Ribeiro afirmava que "a moldura tem que completar o quadro. Ela não pode aparecer, tem que se neutralizar perante a tela (...)" (LOPES, 1988, p. 8).
} 
Em uma entrevista concedida à Daine Lisbona (1974), Jackson Ribeiro afirmou que as suas primeiras pinturas foram destruídas por ele próprio. Durante a pesquisa de arquivo, realizada no Museu de Arte Contemporânea do Paraná, foram encontradas imagens fotográficas de algumas das pinturas de Jackson Ribeiro, datadas de 1959. As pinturas de Ribeiro foram conhecidas pelo amigo e crítico da sua obra, Hélio Oiticica. Oiticica escreveu que as pinturas de Jackson Ribeiro foram as primeiras revelações do que ele viria amadurecer nas esculturas e objetos (OITICICA, 1968). Para Jackson Ribeiro, o ofício na molduraria e as primeiras experiências com a pintura levaram-no a descobrir a sua forma de expressão com a escultura de sucata de ferro. Ele conta:

Eu precisava de uma máquina para engessar as molduras e pintá-las. E como não existia aquilo que eu procurava, resolvi fabricar o aparelho. Foi o contato com essas peças que surgiu minha primeira escultura, um cristo, resultado de toda uma educação católica comum ao nordestino (LISBONA, 1974)

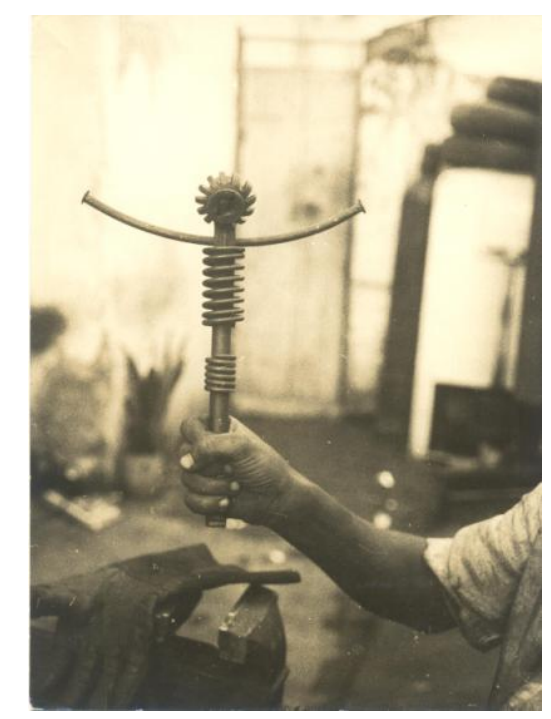

Figura 15 - RIBEIRO, Jackson. Crucifixo, 1959. Ferro. Objeto múltiplo. Foto: Arquivo do artista (Museu de Arte Contemporânea do Paraná)

A partir da afirmação do artista, podemos compreender que o percurso que ele constrói sua linguagem está entrelaçado com a técnica da soldagem e com a experimentação de materiais que resistam a essa técnica e que criam uma expressão vital. A obra Crucifixo, 1959, (Fig. 15, p. 38) foi exposta no $8^{\circ}$ Salão de Arte Moderna do Rio de Janeiro, marcando o surgimento do artista no circuito de arte. Enquanto solução plástica, essa obra tornou-se um objeto múltiplo, ou seja, reproduzida em várias cópias, e seus exemplares figuram coleções privadas de amigos do artista. Tão logo ingressou no circuito de arte, Ribeiro defendeu a 
multiplicação do objeto artístico que, em tese, era uma maneira de reproduzir e disseminar sua obra, para que ela tivesse um consumo acessível. É importante entender que nos anos 1960, a multiplicação de um objeto artístico, para fins de desmistificação do original, foi uma postura corrente entre artistas ligados as tendências da pop art, que utilizavam um protótipo para reproduções ilimitadas. Considerando a emergência de questões que orientam o movimento pop nos anos 1950 e 1960, a atitude de Jackson Ribeiro compartilhava essa racionalidade que provocaria, entre outros aspectos, a mudança do estatuto do objeto artístico de moderno a contemporâneo.

A primeira aparição de uma obra de Jackson Ribeiro no circuito de arte carioca abriu precedente para sua atuação expressiva em mostras e exposições nacionais e internacionais. Foram trinta anos, desde o surgimento do artista até o afastamento espontâneo no circuito de arte, participando de salões e exposições no Brasil e no exterior, premiado em diversos eventos, com obras adquiridas por museus e colecionadores, e objeto de debate entre os críticos de arte mais atuantes da época. Com o afastamento espontâneo do circuito de arte, Jackson Ribeiro tornou-se "um artista de artista", ou seja, um artista conhecido apenas por outros artistas, apreciadores da sua obra. Jackson Ribeiro deixaria de manter relações comerciais com galerias de arte no final dos anos 1980. Com raras aparições no circuito de arte, Ribeiro continuava seu trabalho em uma igreja abandonada que lhe servia de ateliê. Com a saúde debilitada em decorrência de problemas renais, Fernando Jackson Ribeiro morreu em Curitiba, em 19 de outubro de 1997, onde residia desde o início dos anos 1980. A família e os amigos só souberam quando a informação deflagrou nos jornais, o corpo do artista havia sido sepultado como indigente. Posteriormente, os amigos do artista criaram uma lápide para seu túmulo e algumas homenagens lhe foram rendidas.

Nos anos 1980 e 1990, Ribeiro dedicou-se ao projeto do jogo das Decorrências Modulares (Fig. 10, p. 33), no qual o artista experimentava a abstração da forma, a desmistificação do objeto original e, sobretudo, uma relação dialógica intersubjetiva artista/obra/observador, construindo uma educação espacial como linguagem. Apresentaremos detalhadamente esse processo no capítulo seguinte.

\subsection{Aproximações e contaminações entre artes visuais e design ${ }^{4}$}

\footnotetext{
${ }^{4}$ Esse estudo foi apresentado como trabalho de conclusão do curso Aproximações e Contaminações Entre Artes e Design Visual, Arquitetura e Cidade, ministrado pelo Prof. Dr. Sérgio Regis M. Martins, na Faculdade de Arquitetura e Urbanismo da Universidade de São Paulo (FAU USP).
} 
Nos capítulos anteriores apresentamos a construção da linguagem artística de Jackson Ribeiro, identificando as obras salvaguardadas em acervos museológicos no Brasil e conhecendo sua trajetória na molduraria. Havíamos sistematizado a obra de Ribeiro em três fases poéticas, nas quais o artista desenvolve sua técnica, se apropriando de diferentes materiais e construindo uma linguagem própria dentro de um contexto de transição da arte moderna a arte contemporânea. Optamos dar um tratamento distinto à última fase poética do artista, baseada no desenvolvimento do projeto conceitual do jogo das Decorrências Modulares (Fig. 10, p. 33), por se tratar de um momento no qual o artista se aproxima de questões conceituais, presentes na formulação de uma obra/jogo que abstrai a forma e estabelece uma relação direta de participação do observador. A linguagem do artista ganha um amadurecimento e esta fase poética se distingue das demais por criar uma relação de contaminação entre as artes visuais e o design, situando a obra de Ribeiro no terreno do projeto gráfico, embora o pensamento-ação esteja enraizado em conceitos filosóficos como espaço, tempo e sujeito, como trataremos a seguir.

Uma Decorrência Modular está sob a salvaguarda do Museu de Arte Moderna do Rio de Janeiro, em regime de comodato, e pertence a coleção de Gilberto Chateaubriand. Há três outras obras de Jackson Ribeiro que estão sob a salvaguarda do Museu de Arte Contemporânea do Paraná. Essas três obras foram objeto de intervenção da nossa pesquisa, que colaborou com a instituição museológica na sua catalogação. Por sua vez, essa catalogação foi resultado de um estudo no qual refletimos aspectos da obra de Jackson Ribeiro que suscitaram aproximações conceituais das artes visuais e do design. Para tanto, estabelecemos como recorte desse estudo, uma análise de parte do processo poético do artista, que compreende uma obra interativa, o jogo Decorrências Modulares (Fig. 10, p. 33), e seus desdobramentos em série, nomeados pelo artista de Elementares ou D.M. Discutiremos o conceito de espaço, a partir da postura fenomenológica, e algumas características estéticas da obra, a fim de lhe dar inteligibilidade. 


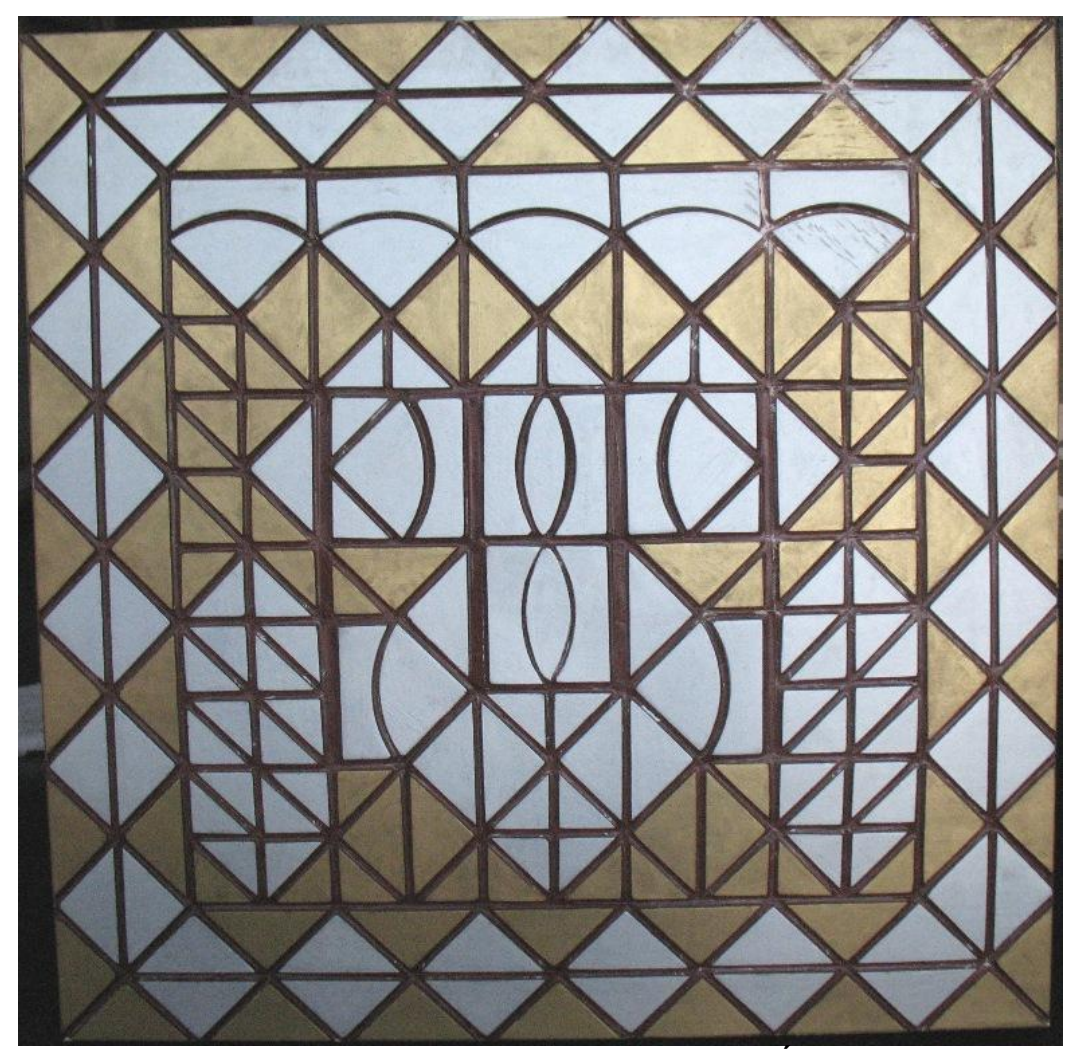

Figura 16 - RIBEIRO, Jackson. Decorrências modulares, 1993. Oleo s/ madeira. Museu de Arte Moderna do Rio de Janeiro. Foto: Museu de Arte Contemporânea do Rio de Janeiro.

A última fase da obra de Ribeiro é marcada pela criação de uma obra conceitual, o jogo das Decorrências Modulares. O projeto da obra conceitual sofreu os percalços que a arte contemporânea passa quando ingressa na estrutura museológica convencional. Esse estudo também se destaca por seu papel em dar inteligibilidade a uma obra de arte, desconhecida pelo museu responsável por sua salvaguarda. Nesse sentido, empreendemos um método de interpretação do arquivo do artista, coletando dados sobre a obra para compreendê-la enquanto tal. O Museu de Arte Contemporânea do Paraná (MAC PR), responsável pelo maior arquivo do artista em acervo museológico, catalogou duas obras de artes de Jackson Ribeiro, que são duas séries de serigrafias sem título. Separadamente, o MAC PR organizou no setor documental o que considerava o arquivo do artista. Em diferentes pastas, 4 fontes documentais foram importantes para catalogar a obra conceitual do jogo das Decorrências Modulares (Fig. 10, p. 33):

a) uma leitura crítica de Hélio Oiticica, publicada no catálogo da exposição individual de Jackson Ribeiro que apresentava o jogo (o manuscrito e sua transcrição também constam em versão digital do Projeto HO - Itaú Cultural $)^{5}$;

\footnotetext{
5 OITICICA, Hélio. Jackson Ribeiro: Do Totem às Decorrências Modulares, Rio de Janeiro, 1979. Disponível em:
} 
b) fotografias de montagens da obra;

c) O projeto gráfico dos módulos, com medidas e desenhos esboçados com a assinatura de Jackson Ribeiro;

d) e por fim, 5 módulos fabricados em alumínio e madeira, armazenados junto com as ferramentas de polimento de ferro, catalogados pelo MAC PR como "matrizes das obras" que constavam no acervo.

A catalogação do MAC PR não deixa de fazer sentido, tendo em vista que as referidas obras são duas séries de Elementares/D.M., desdobramentos do jogo conceitual, previstos no projeto da obra. Entretanto, a maneira como foram catalogados os módulos coloca a preservação dos objetos em risco: quando a caixa é movimentada, as ferramentas e os módulos atritam entre si, desgastando os módulos de alumínio, estes por sua vez desgastando os módulos de madeira. Por outro lado, embora a obra esteja diretamente relacionada ao próprio projeto do jogo, os módulos existentes podem ter a salvaguarda enquanto um exemplar do jogo elaborado pelo artista. Sobre as duas demais obra catalogadas sem título (Fig. 11; Fig. 12, p. 34), temos outra consideração: elas podem efetivamente "não ter título", porém constatamos, em um vídeo-documentário (LINGOCKI, 1990), duas D.M. que são "matrizes" das imagens serigrafadas. Igualmente importante nesse estudo é a elucidação que a pesquisa acadêmica trás à instituição museológica e a necessidade de revisarmos criticamente a estrutura do museu, diante das questões e provocações da arte contemporânea.

Tratamos o nosso recorte como uma fase do processo poético do artista, pois entendemos que sua realização compreende uma totalidade do estudo da forma, que se revela desde suas primeiras criações. Por outro lado, entendemos que este fragmento do seu processo poético é em si uma experiência artística específica, com suas nuances que se destacam formalmente duas obras de arte independentes: o jogo das Decorrências Modulares e os Elementares/DM.

Decorrências Modulares (Fig. 10, p. 33) é uma obra conceitual, cuja realização necessita da participação do observador como agente que intervém tanto na percepção quanto no ato criativo. A obra é um jogo, cuja documentação mais importante é um relato de Hélio Oiticica e os objetos criados pelo artista que estão sob a salvaguarda do Museu de Arte Contemporânea do Paraná (MAC PR). Segundo Oiticica (1979), trata-se de um jogo composto por nove módulos geométricos e Jackson Ribeiro intencionava acrescentar mais quatorze módulos. A proposta da obra era permitir que o jogador reconhecesse as formas 
geométricas e a partir delas construísse combinações. Os resultados seriam diversos, e as combinações poderiam resultar no reconhecimento de figuras ou simplesmente na abstração da geometria das formas. Nesse sentido, entendemos nessa pesquisa que as Decorrências Modulares também revela um aspecto educativo, no qual o jogador reconhece um campo de atuação e formas modulares, e a partir da dinâmica das peças funda um espaço novo (SOARES, 2010d).

O jogo das Decorrências Modulares (Fig. 10, p. 33) se situa no meio de um debate da arte contemporânea, onde destacamos os seguintes aspectos:

a) A partir dessa obra, entendemos que Jackson Ribeiro cria uma história da forma, ou seja, em um primeiro momento o artista busca construir uma linguagem artística identificando as formas dos objetos industriais descartados e lhes propõe um novo contexto. Nesse momento, a dinâmica da sucata, seja na incrustação sobre a pedra, seja na elaboração de um objeto totêmico, é um reconhecimento estético do objeto cotidiano, diferente da postura de Marcel Duchamp, mas que resignifica o conceito dadaísta. Com as Decorrências Modulares o artista abstrai a forma em geometria e as peças passam a funcionar como módulos para construir espaço, tal como um jogo lúdico e poético;

b) os módulos foram elaborados tal como um vocabulário, com significado autônomo, dada a percepção do jogador, e cuja combinação é em si o resultado de um experimentalismo. Assim, entendemos que os caminhos da construção da linguagem de Jackson Ribeiro identificavam as peças de ferro e as pedras como vocabulário dentro da expressão das fases poéticas anteriores;

c) o observador é convidado a fazer parte da obra, intervindo com sua percepção e seu ato criativo, e a condição de sujeito ou objeto é questionada. Esse aspecto dialoga com toda uma geração de artistas contemporâneos à Jackson Ribeiro e responde diretamente aos questionamentos de artistas que conviveram com ele e de alguma maneira participaram da sua obra como Hélio Oiticica, Lygia Pape e Lygia Clark;

d) a experiência com as Decorrências Modulares funda um espaço novo, e seu criador pode reformular e suscitar uma nova experiência, tal como uma educação espacial.

Entendemos o jogo das Decorrências Modulares (Fig. 10, p. 33) como uma obra que nasce de um processo poético preocupado com a questão do espaço e da forma. Representamos esse processo através do gráfico abaixo: 


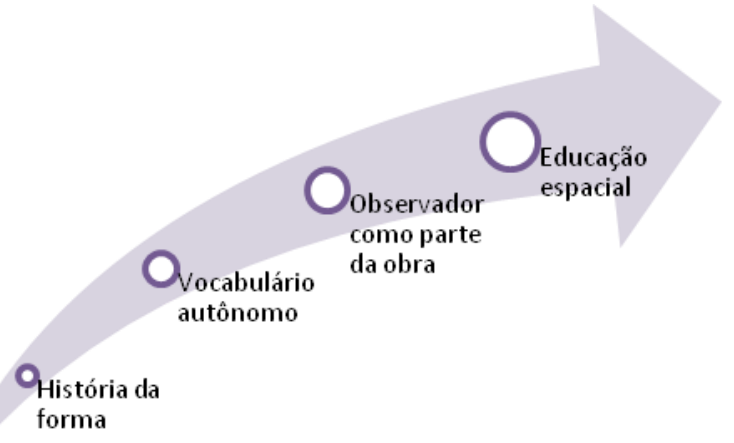

Gráfico 1 - Processo poético de Jackson Ribeiro. (Gráfico nosso)

Objetivamente, a obra tinha dois desdobramentos: um deles eram soluções elaboradas pelo próprio artista e o outro são soluções individuais/coletivas realizadas pelos participantes da obra. Essas combinações múltiplas poderiam ser consolidadas pelo próprio artista, gerando soluções em série, chamadas de Elementares ou DM. A partir do momento que o artista consolida uma solução, esta solução pode servir de matriz para gravações, projetos gráficos digitais, projetos tridimensionais e se desdobrar em outros suportes. Jackson Ribeiro deixa uma obra aberta para a experimentação espacial e para o design. $\mathrm{O}$ artista elaborou dezenas de Elementares/DM, algumas foram expostas em Curitiba e no Rio de Janeiro nos anos 1980 e início dos anos 1990 (CENTRO, 1984). Compreendemos o jogo das Decorrências Modulares como uma obra-projeto, que dá origem aos Elementares/DM, embora ambos sejam criações autônomas. Para Hélio Oiticica (1979), tanto as Decorrências Modulares quanto os Elementares/DM se realizam enquanto "fundamentação de espaço: elas fundam um tipo de espaço sem escala (tal como - guardando as diferenças - descobri na minha própria obra com as maquetes sem escala que ora realizo)" (OITICICA, 1979) (grifo nosso) ${ }^{6}$. É justamente essa concepção de espaço sem escala que faz a obra de Jackson Ribeiro percorrer os caminhos da matemática e da física, criando um jogo contaminado de conceitos artístico-filosóficos presentes no pensamento do neoconcretismo (BRITO, 1999). Essa aproximação conceitual coloca a obra de Jackson Ribeiro no centro das discussões propostas pela arte neoconcreta, o que levanta um problema para os pesquisadores que se aventuram em cercar o neoconcretismo através do método historiográfico. Seguindo as orientações de uma historiografia preocupada em localizar fatos históricos recortados em um tempo e espaço, a obra Decorrências modulares não poderia ser compreendida como arte neoconcreta, pois não foi "concebida" nem por um artista signatário do movimento de arte neoconcreta nem figura a história da arte nos anos 1960 quando da efervescência desse movimento artístico.

\footnotetext{
${ }^{6} \mathrm{O}$ relato de $\mathrm{HO}$ que usamos é uma transcrição de um manuscrito, que compõe o arquivo do projeto HO, digitalizado a partir de um programa do Itaú Cultural. Não sabemos, contudo, quais são as maquetes as quais Oiticica comparou ao trabalho de Jackson Ribeiro.
} 
Como alternativa ao método historiográfico, buscamos nesse estudo realizar uma interrogação filosófica que compreende a historicidade do processo poético do artista. À luz do pensamento de Merleau-Ponty, nosso estudo se orientou pela seguinte prerrogativa:

\footnotetext{
"Não toma por dado o contexto, debruça-se sobre ele para procurar a origem e o sentido das perguntas e respostas, a identidade daquele que questiona, e por ai tem acesso à interrogação que anima todas as questões do conhecimento e que é de outra espécie" (MERLEAU-PONTY, 2007, p. 105).
}

Interrogar o fenômeno que percebemos envolvido pelas Decorrências modulares atravessa a classificação historiográfica de personagens e contexto. Forma, espaço, tempo e estrutura são noções que na obra de Ribeiro estão ligadas a uma significação existencial, quem joga sabe, percebe, sente e se afeta. O jogo em-si coloca a questão da identidade do jogador: quem é criador da obra? Há uma criação genuína de alguém? As Decorrências Modulares estão consoantes aos projetos dos penetráveis de Oiticica ou dos bichos de Clack, são interrogações filosóficas. Para além de uma classificação que busca uma objetividade cega, classifica e categoriza um movimento artístico ou uma obra de arte, o que compreendemos é que, junto a sua geração de artistas, Jackson Ribeiro constrói uma linguagem que ressoa um pensamento presente em toda obra filosófica de Merleau-Ponty: pertence à experiência o poder ontológico último. Quando observamos os Elementares/DM visualizamos que as obras têm desdobramentos que engendram diversas criações. No espaço plano, as imagens saem já da horizontalidade através dos relevos geométricos. Elas podem suscitar novos suportes, decorrentes do uso da tela como matriz para gravura; ou ainda construir ortogonais da vertical, elaborando esculturas. 


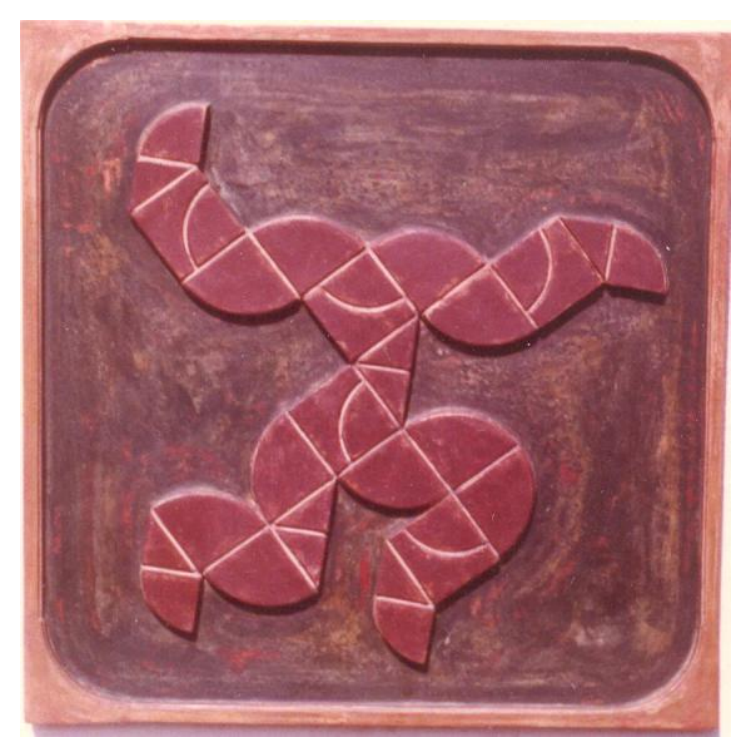

Figura 17 - RIBEIRO, Jackson. Decorrências Modulares, (?). Pintura sobre madeira. Foto: Arquivo do artista (Museu de Arte Contemporânea do Paraná).

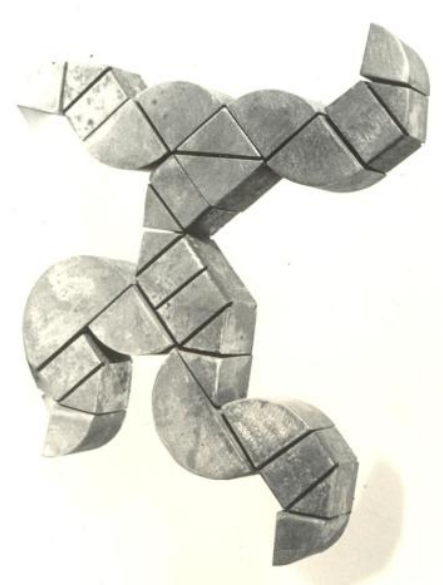

Figura 18 - RIBEIRO, Jackson. Decorrências Modulares, (?). Objeto. Foto: Arquivo do artista (Museu de Arte Contemporânea do Paraná).

Continua a questão da experiência na obra de Ribeiro. O espaço ganha uma nova dinâmica quando a solução plástica da obra ganha um novo desdobramento. Se a experiência com o jogo motiva uma criação, o resultado não é final, ele pode gerar novas soluções que são, literalmente, decorrências modulares de uma estrutura elementar. A estrutura elementar a qual falamos, e que é a essência da obra de Jackson Ribeiro, é uma estrutura motivada: as formas enquanto vocabulário são motivos que podem ser jogados, ou melhor, ligados, conjugados e aproximados com outros motivos.

Vejamos as soluções a seguir, que geraram a escultura "Homem de vendas", 1984 (Fig. 19, p. 46): 

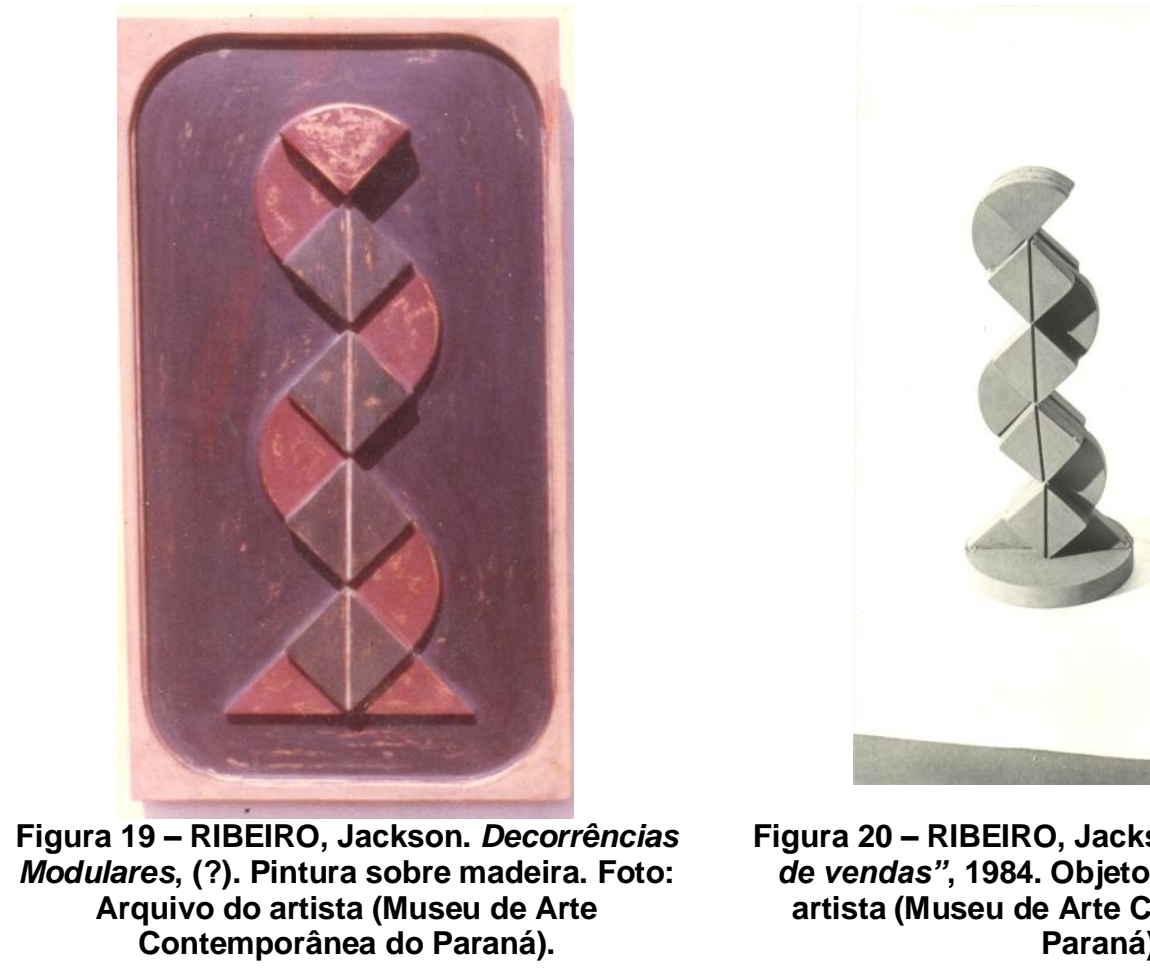

Figura 20 - RIBEIRO, Jackson. Troféu "Homem de vendas", 1984. Objeto. Foto: Arquivo do artista (Museu de Arte Contemporânea do Paraná).

Se observarmos como a linguagem das artes visuais penetra um campo matemático e físico, entenderemos que as esculturas citadas anteriormente também são exemplares de projetos de produto. Nesse sentido, a criação do artista permeia o campo do design e a obra de arte passa a compor um projeto. Por outro lado, podemos entender que o processo de criação trás em si um potencial de design. A partir dessa obra evidenciamos que o artista aproxima/contamina artes visuais e design. Entendemos que a intencionalidade simétrica dos Elementares/DM, ou ainda anterior, no jogo Decorrências Modulares (Fig. 10, p. 33), já indica o caráter de design da obra. Esta, por sua vez, cria uma experiência espacial única, que é motivada pela criação. “(...) geometria como expressão desse espaço não visível entre as coisas, ou seja - como indicou Merleau-Ponty -, sua profundidade, é que traz à tona o pensamento do espaço enquanto plenitude e positividade” (DOCTORS, 1991).

Considerando que a linha tênue, que aproxima as artes visuais e o design na obra de Jackson Ribeiro, é a experiência que cria o espaço, faz-se necessário compreender esse conceito que os entrelaça.

Há um conceito filosófico que se aproxima da perspectiva experimental da obra de Fernando Jackson Ribeiro. Maurice Merleau-Ponty (1942) quando desenvolve seu estudo concernente à fenomenologia da percepção discorre a respeito de uma distinção entre espaço espacializado (l'espace espacialisé) e espaço espacializante (l'espace espacialisant). Para o 
autor, a primeira noção estaria orientada à qualidade do espaço, à sua variação, tal como entendemos e distinguimos apreensões: alto e baixo, esquerda e direita, longe e perto, etc. A segunda noção concerne à condição indivisível e imutável do espaço. Esta por sua vez não está orientada por apreensões externas sobre o espaço, não é objeto da experiência do indivíduo, ela é uma condição que existe e pode ser percebida quando o indivíduo se compreende integrante do espaço. Ela é construção que parte de uma interioridade, motivada e motivando uma experiência.

O jogo das Decorrências Modulares (Fig. 10, p. 33) revela algo próximo à noção de espaço espacializante. É um projeto que propõe formas para serem dinamizadas, mas não determina leituras. A imagem construída pode ser figurativa ou abstrata, dependendo da montagem e do observador. A imagem é construída pelo relevo das formas, sem determinar uma medida de espaço para ser compreendida. Assim, dois observadores diferentes podem perceber duas figuras de tamanho diferentes. A linha do desenho é livre para a criação e para leitura, sem a necessidade de uma escala.

O jogo das Decorrências Modulares consegue, na gênese, sintetizar uma ligação entre arte e design. $\mathrm{O}$ artista cria um projeto que se preocupa menos com uma solução única e formal, ele semeia um terreno que pode germinar diferentes e infinitos frutos. Nesse sentido, não é uma solução final que lhe interessa, mas a experiência do indivíduo de criar seu espaço a partir de combinações ilimitadas. Nesse sentido, Jackson Ribeiro nos convida a pensar o design a partir da colaboração, ou seja, da ação conjunta, coletiva, que funda um espaço indivisível porque está em uma compreensão interna a experiência do(s) sujeito(s). Em outras palavras, a noção de espaço é criada a partir da relação intersubjetiva artista/criação/observadores. Os módulos criados pelo artista funcionam como um vocabulário abstrato, cujas construções se configuram tal como um texto visual, que é autônomo em relação ao seu criador, pois está igualmente sujeito à experiência de outros observadores. Cada solução é nova para quem cria e nova para quem observa. Ela é infinita porque, embora esteja codificada por formas pré-elaboradas, também motiva a imaginação de outras pessoas. Eis o que Hélio Oiticica entendeu como "fundamentação do espaço":

Há como se vê um mundo de possibilidades em decorrência do principio TOTEM levado a cabo por Jackson desde o principio de sua caçada criativa: AS DECORRÊNCIAS MODULARES DECORREM DO PRINCIPIO TOTEM E FUNDAM ESPAÇO e essa experiência faz parte da grande demolição do espaço antigo da escultura e da pintura e propõe algo que aponta para O NOVO: algo que elimina a possibilidade de combinação e cultivação do espaço-forma antigo da 
escultura e do TOTEM-FOLCLORE mistificantes é a negação e a eliminação do folclore (ligado este às chamadas "raízes primitivas" que nada mais são do que a manutenção de formas esquálidas e acadêmicas de arte) e do espaço tradicional da escultura tal como é manifestada pelos realizadores de tais formas de arte, AS DECORRÊNCIAS MODULARES SÃO DECORRÊNCIAS QUE GERAM O NOVO! (OITICICA, 1979).

Finalmente, o jogo das Decorrências Modulares (Fig. 10, p. 33) e suas soluções, os elementares/D.M., fazem parte de um processo poético crítico à noção de espaço. É um projeto construtivo que compartilha do ideal de uma arte que integra artista, obra e observador, questionando a identidade do sujeito e do objeto. As Decorrências Modulares é um jogo que motiva os indivíduos a deixar a condição passiva de contemplar para desempenhar a ação de projetar, de desenhar um espaço a partir de construções, que são criações que surgem como interface da percepção dos indivíduos. Embora as soluções elaboradas pelos jogadores sejam em si novas criações, o que interessa ao artista é a experiência que o indivíduo tem com o jogo e a possibilidade de visualizar seu processo poético a partir da percepção espacial. Para Jackson Ribeiro, não era nem o módulo nem a solução da conjunção dos módulos que lhe interessava, mas a experiência do indivíduo com a obra:

\footnotetext{
"Digo: o real não está na saída nem na chegada: ele se dispõe para a gente é no meio da travessia" (ROSA, 2001, p. 80).
}

\subsection{Reflexões sobre as relações entre artes visuais, arquitetura e cidade: o caso da obra pública $O$ Porteiro do Inferno}

Antes de se mudar para a Europa, em 1965, Jackson Ribeiro elaborou uma obra pública para ser instalada na cidade de João Pessoa. A obra era esperada por artistas e crítico locais como um exemplar do renomado artista plástico conterrâneo. Nesse contexto, Jackson Ribeiro era considerado uma das referências da escultura brasileira, conhecido pela crítica de arte e com obras adquiridas por importantes museus e colecionados. Antes de Jackson Ribeiro, poucos paraibanos tinham se destacado no circuito brasileiro das artes plásticas, os exemplos mais expressivos foram o cenógrafo e artista gráfico Tomás Santa Rosa, responsável pelos projetos gráficos dos livros do editor José Olympio e por cenários de peças de Nelson Rodrigues, e o pintor Pedro Américo, autor de célebres pinturas históricas do período imperial. O projeto de uma obra pública de Jackson Ribeiro foi adquirido pelo 
governo do Estado da Paraíba, durante a gestão de Pedro Gondim. A obra foi elaborada em um galpão, improvisado como ateliê do artista, e ficou pronta em 1965, mas permaneceu guardada, e somente dois anos mais tarde, foi instalada na Av. Getúlio Vargas (O NORTE, $1966)^{7}$.

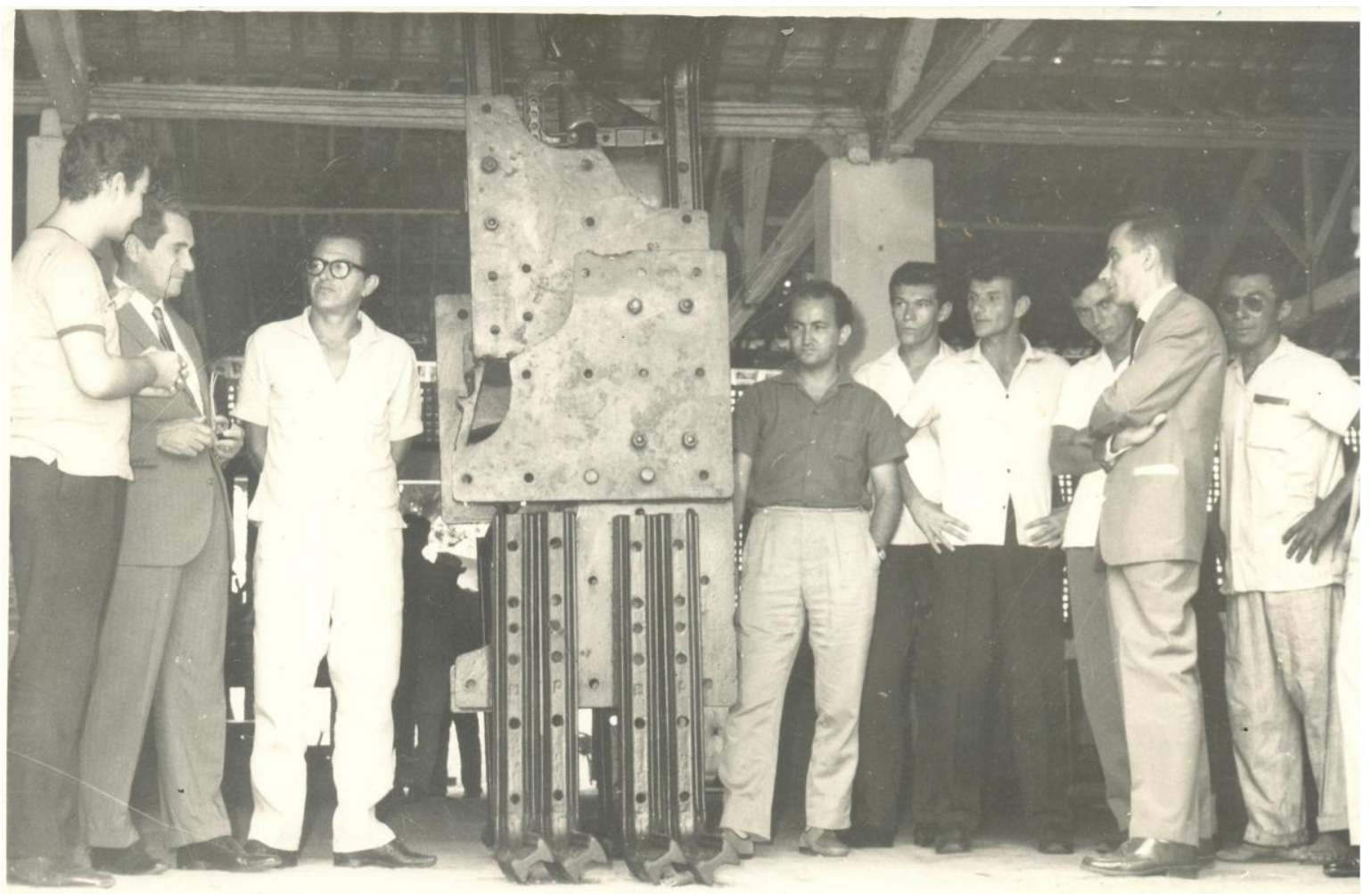

Figura 21 - APRESENTAÇÃO da obra Porteiro do infeiro, 1965. Da esquerda para a direita vê-se o crítico de arte Raul Córdula (primeiro) e Jackson Ribeiro (terceiro). Foto: Arquivo do artista (Museu de Arte Contemporânea do Paraná)

O lugar escolhido para instalação é fundamental para compreender a importância que tinha a obra de Jackson Ribeiro para o cenário artístico paraibano. A obra pública foi alocada em uma praça, localizada dentro de um contexto arquitetônico e urbanístico com influência modernista. O prédio com detalhes de uma arte décor, projetado pelo arquiteto Clodoaldo Gouveia, funcionava a antiga Faculdade de Filosofia (FAFI) e o Liceu Paraibano. Localizado na Av. Getúlio Vargas, o prédio está integrado e dialoga com o projeto urbanístico do Parque Sólon de Lucena, projetado pelo arquiteto e artista plástico Roberto Burle Marx. Percebemos, nesse contexto, como a (re)construção do espaço urbanístico da cidade de João Pessoa expunha determinadas escolhas de tendências artísticas. A obra foi nomeada popularmente como "Porteiro do Inferno", porém não existe um consenso sobre como surgiu o nome;

\footnotetext{
${ }^{7}$ Os relatos mais recorrentes indicam que o artista plástico Breno Mattos e o crítico Vigínius da Gama e Mello promoveram a exposição pública e instalação da obra, até então desconhecida da sociedade.
} 
algumas narrativas atribuem ao crítico Vigínius da Gama e Mello. Segundo Raul Córdula ${ }^{8}$, membro da Associação Brasileira de Críticos de Arte, na época quando a obra foi instalada nesse logradouro, algumas pessoas deixaram flores, plantas com valores místicos e velas criando uma atmosfera religiosa para a obra pública; a mesma informação foi encontrada em um texto escrito por Hélio Oiticica (1968).

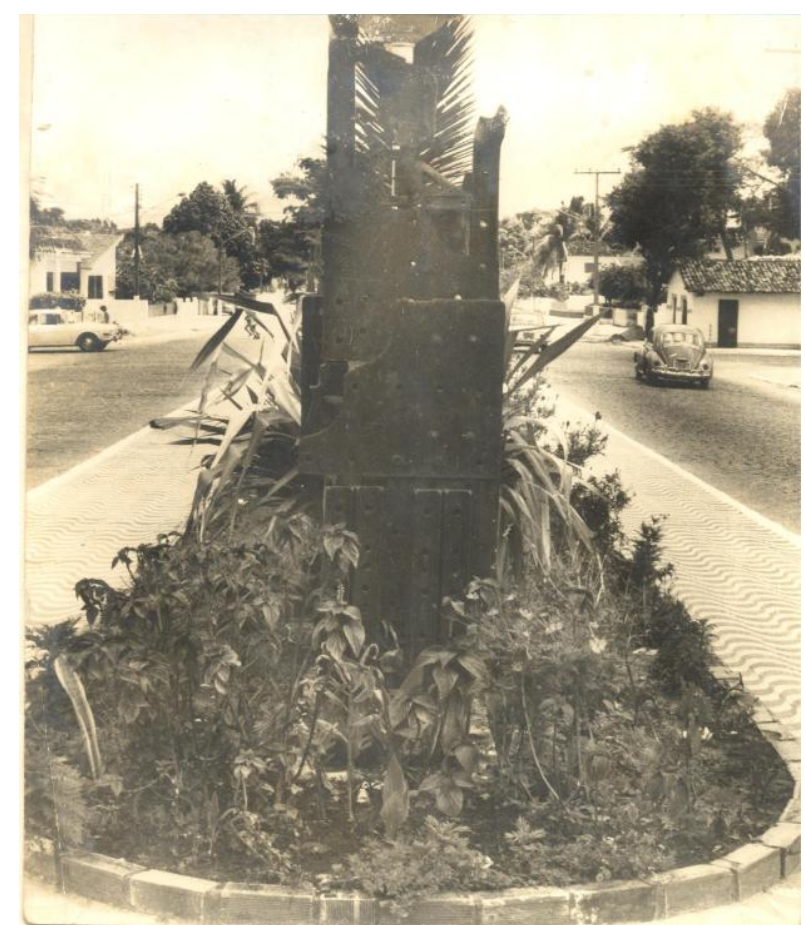

Figura 22 - RIBEIRO, Jackson. Porteiro do inferno, 1967, obra pública instalada na Av. Getúlio Vargas. Foto: Museu de Arte Contemporânea do Paraná.

Entretanto, o nome da obra e sua possível divinização não agradaram aos membros da Primeira Igreja Batista, instituição religiosa cristã de denominação protestante, que também se localizava na Av. Getúlio Vargas, nas mediações onde fora instalada a obra pública. Igualmente, é interessante marcar como a obra de arte, em um contexto de fetichização, ganha atribuições distintas quando associada a um discurso religioso. Helio Oiticica (1968) já havia apontado sobre o caráter fisionômico da obra de Jackson Ribeiro, e os motivos os quais levaram a nomeação das obras pelos observadores. A questão era inquietante para Jackson Ribeiro, que se orientava por questões estéticas e buscava uma abstração da forma. Mas, por outro lado, a estrutura totêmica dos objetos revelava aspectos fisionômicos, o que também

\footnotetext{
${ }^{8}$ Durante a mesa-redonda "Helio Oiticica e Jackson Ribeiro: do neoconcreto à arte pública", com a participação de Raul Córdulo (ABCA/AICA), Walter Galvão (UFPB) e Stênio Soares (USP), realizada no dia 19 de março de 2010 na Usina Cultural Energisa/Fundação Ormeo Junqueira Botelho. Atividade da programação da exposição "Helio Oiticica e Jackson Ribeiro: do neoconcreto à arte pública", sob curadoria de Dyógenes Chaves.
} 
aproximava seus trabalhos às expressões da nova figuração. Segundo Oiticica (1968), o problema das características fisionômicas dos objetos de Jackson Ribeiro revela também "a possibilidade de uma obra que não tem um significado $\mathrm{x}$, mas que possua uma estrutura que nos interessa enquanto que aberta aos significados" (OITICICA, 1968). Surgiu um impasse quanto à permanência da obra pública nessa praça e que culminou na sua retirada.

A saga da obra "O Porteiro do Inferno" durou 40 anos, desde sua instalação em 1967, posteriormente migrando para diferentes lugares da cidade, até em 2007 quando afixaram-na em uma rotatória em frente à Universidade Federal da Paraíba (UPFB). A obra também foi objeto de debates no cenário político da cidade, quando parlamentares da câmara municipal acataram as cobranças de líderes religiosos católicos e protestantes sobre a retirada da obra em frente à UFPB. Na ocasião, os artistas locais se organizaram em um movimento de reconhecimento e valoração da obra de Jackson Ribeiro. Passeatas, encontros universitários e a presença na mídia local estavam mais preocupados em falar sobre a importância da obra e do artista para a história local, ao invés de se debruçar sobre a linguagem do artista. Nesse mesmo ano, duas diferentes ações foram executadas pela Prefeitura Municipal de João Pessoa e pelo Governo do Estado da Paraíba. A Fundação Cultural de João Pessoa (FUNJOPE), órgão de administração indireta da Prefeitura, cria o edital público Jackson Ribeiro, para seleção de obras públicas para a cidade de João Pessoa; o edital foi uma das ferramentas criadas para endossar o reconhecimento da obra de Jackson Ribeiro e para incentivar os artistas locais a criarem obras públicas para a cidade. Já o governo do Estado, por meio da Curadoria de Artesanato da então Subsecretaria de Cultura do Estado da Paraíba emitiu um parecer alegando que a obra originalmente recebeu o nome de "astronauta", em referência à chegada do homem a lua. Ao conversar com alguns conselheiros que assinaram esse parecer, o argumento era que precisavam criar alguma ferramenta que pudesse desmistificar a obra de Jackson Ribeiro a fim de fazer a sociedade entendê-la como expressão artística. No entanto, entendemos que essa intervenção do Estado reafirmou o discurso fetichista que cerca essa obra, bem como negligenciou a afirmação do próprio Jackson Ribeiro, quando se referia a obra pelo nome Porteiro do inferno na reportagem de Maria Eduarda Souza (1978). Em contrapartida, os escritos de Helio Oiticica (1968) já se referiam a essa obra pelo nome Porteiro do Inferno anterior ao ano de 1969, quando se noticiava a chegada do homem à lua. Jackson Ribeiro costumava nomear suas obras de elementares e construções, uma nomenclatura usual entre artistas que pensavam seus trabalhos de maneira abstrata, todavia o dialogo que os objetos construíam com o público observador sempre abriu margem para nomeação popular das obras, o que destaca também o potencial figurativo da poética do 
artista. Mas, nomeada pelo artista ou alcunhada pelo diálogo poético com público, a obra certamente não tem vínculo a ideologia estadunidense da conquista do espaço, considerando também que Jackson Ribeiro era um comunista declarado. Passados três anos, a polêmica sobre o nome da obra se reacendeu e foi estendida à campanha eleitoral de 2010, quando o então prefeito da cidade de João Pessoa candidatou-se à Governador do Estado da Paraíba. Durante a campanha eleitoral, panfletos jogados de helicóptero, "demonizavam" a campanha deste candidato, associando esse prefeito a um discurso de "demonização". Depois de décadas, a obra de Ribeiro ainda carrega o estigma do fetiche, serve de especulação na disputa pelo poder e, em débito com a poética do artista e sua importância para história da arte, é pouco conhecida entre seus conterrâneos.

Mesmo com a mudança da obra para diferentes lugares na cidade, um elemento se encontra constante e presente: o lugar e o tempo da obra de arte, ou seja, sua existência e a significação dela em cada lugar que a colocaram. É a própria existência da obra Porteiro do Inferno que inicia a narrativa sobre sua própria história. Sua existência não compreende somente as transformações que ocorreram durante os mais de quarenta anos, mas como essa obra de arte ingressou em um sistema de relações sociais. Através de sua historicidade podemos identificar os vestígios de alguns discursos religiosos, políticos e artísticos, que cercam o fenômeno de fetichização da obra de arte. Como foi sugerido por Hélio Oiticica (1968), a recepção da obra de Ribeiro acontecia tal como uma "transposição definitiva da condição de "obra de arte" isolada como tal para a de objeto mágico de fruição coletiva" (OITICICA, 1968). A mudança de contexto, ou sua ampliação, segue questões sobre a existência e a natureza da própria obra: ao transformar a obra de arte em um objeto de valor religioso, os observadores apontavam que a obra de arte é algo aberto para criação além do trabalho do artista.

Em seu ensaio sobre a reprodutibilidade técnica, Walter Benjamin (1994) afirma que "no interior de grandes períodos históricos, a forma de percepção das coletividades humanas se transforma ao mesmo tempo que seu modo de existência" (1994, p.169). Nessa dissertação entendemos que a percepção e o envolvimento dos observadores estão ligados, entre outros aspectos, ao caráter fisionômico da obra. No caso da obra em questão, a nomeação pode ter se dado por diferentes motivos que, necessariamente, não interessam ao nosso estudo. Mas entendemos que existe uma realidade, integrada por discursos divergentes, que constrói uma aura para a obra "Porteiro do Inferno". Não bastava que o objeto artístico estivesse fixado em frente a uma igreja cristã, mas tão somente seu nome marca um significado para sua existência na realidade cultural da cidade. O caminho percorrido pela obra errante e as 
manifestações públicas mostram o caráter de unidade e durabilidade que definem sua aura. Criaram um invólucro, marcando etiquetas com características e adjetivos de um determinado discurso religioso, estabelecendo uma relação aurática com a obra de arte.

Para além do debate entre os discursos religiosos e políticos, entendemos que a obra "O Porteiro do Inferno", quando era localizada no seu primeiro logradouro, motivava uma outra percepção a respeito da simetria, diferente dos ideais modernistas, e o material usado para sua composição era uma evidente crítica ao discurso de industrialização da modernidade. Enquanto uma obra de arte pública, o trabalho de Jackson Ribeiro foi construindo de maneira racional, sustentado pela poética do artista que envolvia a apropriação crítica da sucata, e pretendia ser também crítica na sua exposição pública em diálogo com a arquitetura e o urbanismo. Nesse contexto expositivo, a obra de Jackson Ribeiro era vanguardista e contemporânea quando dialogava com dois exemplares da educação espacial modernista - o prédio de Clodoaldo Gouveia e o paisagismo de Roberto Burle Marx.

Quando observamos a obra entendemos a preocupação de Jackson Ribeiro em construir um objeto que conseguisse dialogar sua linguagem artística com o espaço público, sem o referencial do espaço fechado da galeria. Porteiro do inferno não foi construída para um lugar específico, embora o artista tivesse consciência de que a obra seria situando entre instituições, discursos e outros fenômenos sociais. A obra foi pensada para dialogar com o espaço, onde houvesse arquitetura, plasticidades e visualidades. Contudo, o artista não teria pensado uma obra com um sistema de blindagem para a cidade e a cultura, pelo contrário, sua linguagem sempre motivou a participação do observador. Em uma leitura da obra é perceptível sua forma e seu material construtivo. Para além da materialidade e estética do objeto novas questões se deflagravam a partir do olhar atento e que não cabe mais a uma observação descomprometida. Porteiro do inferno é uma escultura que mede mais de $2 \mathrm{~m}$ de altura e seu material é uma construção de ferro-velho. O volume sugere algumas formas que nos faz perceber e dialogar de outra maneira com o espaço; o desenho que o objeto sugere assemelha-se a um figurativismo, o que faz a imaginação ir mais além. Certamente, a imaginação, que é um fenômeno interior ao indivíduo, quando está em estreito diálogo com a cultura permite-se entrelaçar a determinados discursos, pois a cultura guarda seu caráter ideológico. Porém, a figura, que julgamos a primeira vista ser incompreensível, criava outros sentidos. Nessa relação com a 
obra, o observador é interrogado e suas perguntas são orientadas também para si: o que é, ou melhor o que foi esse ou aquele fragmento de ferro usado na construção? Embora, suspeitamos da origem de alguns fragmentos do objeto, resta-nos duas questões que precisariam ser respondidas para além do visível: porque o autor usou a sucata? E como ele desenvolveu uma técnica para compor um objeto totêmico, expressivo, cujas figuras saltam aos olhos e despertam sentidos? Essas são questões colocadas a partir de uma primeira leitura da obra, de uma abstração inicial, e transformam-se em uma indagação, cujas possíveis considerações estariam na nossa experiência com a arte, com o conhecimento que cultivamos

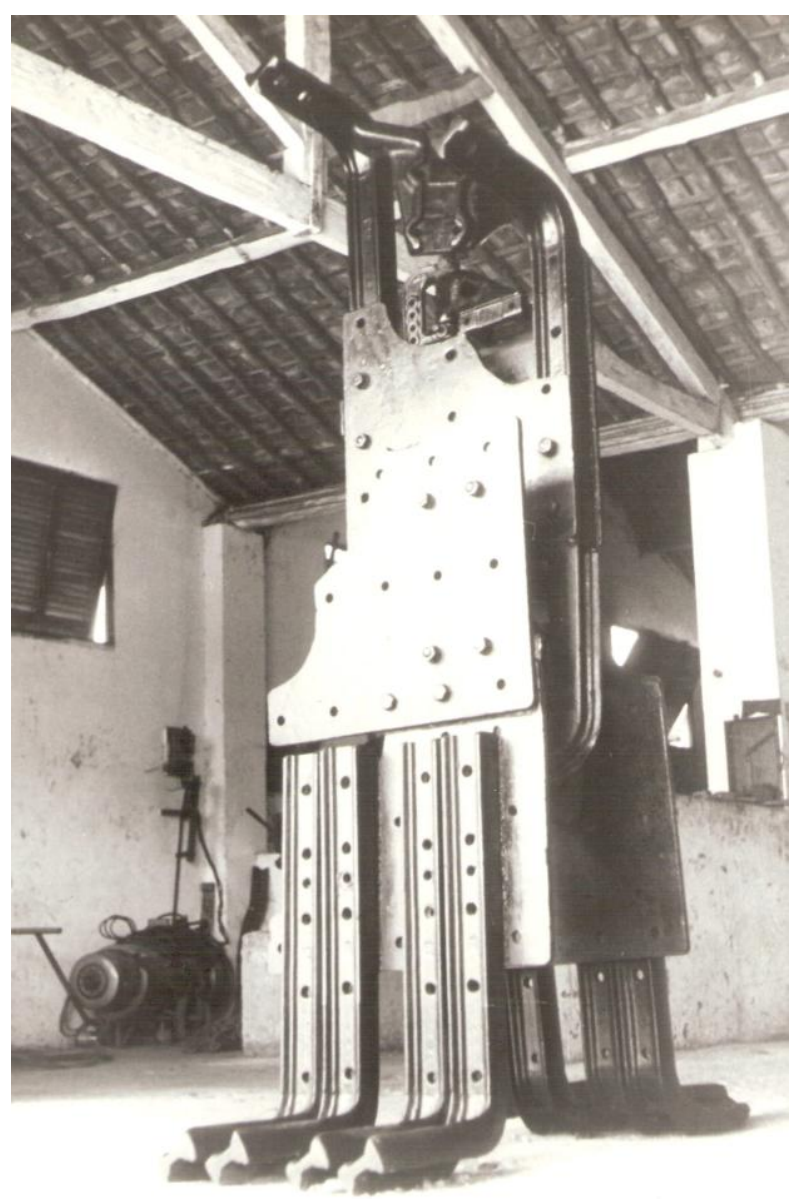

Figura 23 - RIBEIRO, Jackson. Porteiro do inferno, 1965. Ferro. Obra pública instalada atualmente em uma das rotatórias ao lado da UFPB, em João Pessoa. Foto: Arquivo do artista (Museu de Arte Contemporânea do Paraná).

e, para tanto, está em constante aprofundamento. Seria desconexo pensar que essa obra de arte se coloca somente exterior à minha experiência, colocando nossa relação como produto de relações de causalidade: ora, se essa relação com um objeto expressivo desperta-nos sentidos, tratava-se de uma interioridade que se exteriorizava a partir da criação. Se não houvesse a criação do artista não poderíamos experimentar aquela indagação. Negar essa indagação seria recusar conhecer a obra, que encontra uma comunicação, também, através dos sentidos. 
Finalmente, entendemos que o que cerca o problema da fetichização da obra de Jackson Ribeiro é uma determinada postura que pretende explicar a obra de arte a partir da síntese, sem permitir que o observador da obra seja participante e criador dela, realizando uma experiência de pensamento. Se pensar é circunscrever um campo para pensar (CHAUI, 2005, p.148), quando nos ocupamos em compreender a obra de Jackson Ribeiro, revisitando seus caminhos para a construção da linguagem, estamos realizando nossa experiência de pensamento. Assim, não desejamos explicar um objeto ou a obra do artista, mas nos permitimos tão somente a experimentá-la. Pensamos um impensado motivado pela obra de arte, realizamos uma relação de interioridade-exterioridade, fundamos uma relação reflexiva que não deseja dizer o que é, mas indagar o que somos. Porteiro do inferno desperta as sensibilidade a partir da sua origem no observador, embora a própria obra seja o "originário da linguagem como sensível" (CHAUI, 2005, p.149). Cada diferente olhar de um novo observador encontrará na experiência sensível suas próprias questões e respostas.

\footnotetext{
"Provo desta maneira ao mundo odiento

Pelas grandes razões do sentimento,

Sem os métodos da abstrusa ciência fria

E os trovões gritadores da dialética,

Que a mais alta expressão da dor estética

Consiste essencialmente na alegria”.
}

(Augusto dos Anjos)

\section{AS EXPERIÊNCIAS DE PENSAR A OBRA DE JACKSON RIBEIRO}

Parte do estudo que realizamos aconteceu com o acesso aos arquivos dos museus de arte, que salvaguardam obras de Jackson Ribeiro. Como não pretendíamos um estudo de arquivos, recortamos as narrativas que nos dessem pistas sobre a recepção da obra no circuito de arte. Foi quando encontramos os textos de críticos de arte que, ao fazer a leitura da obra de Ribeiro, realizaram sua experiência de pensamento.

Quando entendemos as leituras dos críticos como experiências de pensar a obra de Ribeiro, não objetivamos sistematizar um estudo sobre o discurso da crítica de arte. Se 
fossemos por esse caminho, precisaríamos identificar e analisar as instituições que cercam a formação dos discursos e, certamente, cairíamos no problema de lidar com os enunciados e com a lógica interna das narrativas. O interesse desse tipo de estudo seria o de buscar as contradições, mudanças de pensamento, problemas de abordagem que um grupo de pensadores teve quando se depararam com os caminhos da construção da linguagem do artista. Diferente de uma análise de discursos, quando trazemos à luz as citações de alguns pensadores, pretendemos identificar as interrogações colocadas por esses pensadores. O que motiva a ideia do pensador ou qual motivo invisível anima seu pensamento? Nesse momento, buscamos saber o que engendra essa realidade interna que percebemos na nossa leitura e que também está presente em outras leituras. Qual realidade é percebida pelos leitores da obra que se conecta entre si e ressoa como vibrações de notas musicais no espaço?

A organização desse capítulo aconteceu da seguinte maneira: na primeira parte, trouxemos os críticos como observadores e leitores da obra, para entender qual o envolvimento que a obra promoveu a ponto desses observadores realizarem uma experiência de pensamento a partir de uma motivação artística; na segunda parte, citaremos os críticos que compreenderam a linguagem de Jackson Ribeiro situando-a em um panorama da história da arte, junto à linguagem de outros artistas da sua geração. Nesse sentido, situamos o pensamento dos críticos como compreensões de uma realidade interna, a partir da relação intersubjetia artista/criação/observador. Ao passo que entendemos também que alguns críticos situaram a obra partir do estatuto do objeto artístico, o que leva a entender que identificaram a obra de Jackson Ribeiro dentro de um determinado tempo da história da arte.

Finalmente, introduziremos questões já observadas por outros críticos e que, de alguma maneira, margeiam nossa indagação filosófica.

\subsection{As experiências de leitura da obra feitas pelos críticos de arte}

Como vimos na sessão anterior, a primeira aparição de uma obra de Jackson Ribeiro no circuito de arte foi no $8^{\circ}$ Salão de Arte Moderna do Museu de Arte Moderna do Rio de Janeiro - MAM RJ, em 1959. Nesse salão, Ribeiro apresenta um crucifixo, feito com peças de ferro de diversas origens (Fig. 15, p.38). Esta obra era um objeto múltiplo e teve, posteriormente, ampla circulação. Empenhando em um estudo a partir da pedra bruta e do ferro pré-industrializado, em 1960, Jackson Ribeiro expõe no $9^{\circ}$ Salão de Arte Moderna do 
MAM RJ e é premiado ${ }^{9}$. Sua obra motiva reflexões de críticos e artistas atuantes no circuito de arte, entre os quais, José Roberto Teixeira Leite, então diretor do Museu Nacional de Belas Artes (MNBA), e Mário Pedrosa, então diretor do Museu de Arte Moderna de São Paulo (MAM SP), que comentaram a seleção e premiação dos objetos de Ribeiro no Salão de 1960:

\begin{abstract}
“Ambas essas peças possuem vitalidade. O que é vitalidade? É uma qualidade íntima, uma espécie de vida interior que informa a obra de arte, fazendo-a viver de uma existência própria. É uma alma, um sopro a animá-la. Na obra que sem ela ficaria oca, vazia de sentido. (...) Mas ela está presente nas esculturas de Jackson Ribeiro expostas no Salão. (...) Tem assim as peças de FJR (Fernando Jackson Ribeiro) vitalidade e sensibilidade, (...) Mais duas qualidades, porém, é possível descobrir nas peças mencionadas: 1) força poética, aqui entrando o termo em sua acepção de poder criador, inventiva; 2) adequação entre o que o artista desejou fazer e o material de que lançou mão - o "valor maiêutico do meio expressivo" na expressão de Gillo Dorfles - e entre a idéia inicial e as dimensões da obra final (seria outro o resultado, caso "Um elementar" fosse por exemplo elaborado em mármore ou se medisse meio metro de altura). Em suma: Fernando Jackson Ribeiro pegou de um bocado de ferro velho, e com ele fez nascer um micharoço de vida, que até assustou o velho crítico Reis Júnior ... Esse senhor nega a tal peça, qualidades estéticas, mas em verdade o que lhe está negando é “ beleza”, beleza no sentido helênico da palavra" (LEITE, 1960).
\end{abstract}

Percebemos na leitura do texto de Teixeira Leite que as obras de Jackson Ribeiro motivam reflexões sobre a estética, o caráter plástico dos objetos e a sensibilidade. Isso quer dizer que a obra em si provoca uma experiência de pensamento que, seja exterioridade seja interioridade, já é em si uma experiência. As qualidades observadas nas obras revelam um motivo central: a vitalidade. Se observarmos o argumento de Teixeira Leite, entenderemos que a "força poética e a adequação entre o objetivo do artista e o material usado" são como linhas que orientam o trabalho do artista, se unem e se enlaçam em uma trama, tal como a ideia "motivo" de Merleau-Ponty (1945, p. 208). Ou seja, a "vitalidade" da obra de Ribeiro não é uma "causa" passada, mas uma inquietação que motiva a obra, sustentando a experiência de pensamento de quem tem contato com ela. O motivo, afirma Marilena Chaui (2002, p. 22) é aquilo que vai surgir e, concomitante, é o que orienta esse surgimento.

\footnotetext{
${ }^{9}$ Essa fase integra as obras Elementar n. 5, pedra e ferro, 1960 (Fig. 1, p. 22) e Elementar 4, pedra e ferro, 1960 (Fig. 2, p. 22).
} 
Como numa tapeçaria, numa renda, num quadro ou numa fuga, nos quais o motivo puxa, separa, une, enlaça e cruza fios, traços ou sons, configura um desenho ou tema a cuja volta se distribuem os outros fios, traços ou sons, e orienta o trabalho do artesão e do artista, assim também o motivo central de uma filosofia é a constelação de palavras e de ideias numa configuração de sentido (CHAUÍ, 2002, p.22).

A obra de Ribeiro se revela de maneira especial para cada crítico de arte. O que motiva as considerações de Mário Pedrosa (1960) sobre as qualidades da obra de Ribeiro é a experimentação de materiais menos convencionais, que apontam uma transformação na escultura tradicional. Pedrosa faz uma leitura situando a obra de Ribeiro dentro de um determinado contexto da História da arte.

“(...) e não falemos desse anônimo verdadeiro artista que é Fernando Jackson Ribeiro, que já conjuga a pedra e o ferro de modo justo, dando com isso uma lição a muito escultor de fama que por aí anda: sua Figura é obra de autêntico arcaísmo expressivo. Nos envios de escultura deste ano nota-se a predominância do elemento espontâneo que nos estava faltando prenhe de humor e de significação mágica. A escultura tradicional praticamente desapareceu, enquanto começam a aparecer objetos no espaço de quaisquer materiais que, se mais longe das belas-artes, mais próximas estão, porém, da criação popular. Isso também representa um progresso" (PEDROSA, 1960).

“Arcaísmo expressivo". É interessante refletir como Mário Pedrosa pensou a obra de Jackson Ribeiro, situando sua criação em diálogo tanto com o arcaísmo enquanto expressão no campo da memória histórica, do arqueo, do velho enquanto forma pré-existente em um tempo histórico. Ao passo que esse arcaísmo se desvela através de imagens que semelham uma postura expressionista, como se a obra revelasse figuras com emoções ou sentimentos, como o humor, e tivesse uma relação com a vida espiritual, como uma significação mágica. Assim, o que Mário Pedrosa destaca é o aspecto expressionista também marcado pelo uso que Jackson Ribeiro empregou ao material escolhido, assim como as formas conjugadas que dão visualidade a uma figura emotiva. Para Pedroso, a linguagem artística de Ribeiro motiva novos significados aos objetos achados, como se o artista não quisesse apenas reproduzir a realidade e buscasse criar uma escultura com a espontaneidade da criação popular. Essa abordagem coloca a criação de Jackson Ribeiro como transformadora da realidade, no sentido de construir uma linguagem distante da orientação formalista, como no contexto das escolas 
de Belas-Artes. Assim, entendemos que Mário Pedrosa destacava na obra de Ribeiro a conjunção de formas abstratas, que buscam criar uma nova visualidade.

Uma questão se coloca fundamental, quando nos referimos aos termos e categorias nas artes visuais. Pedrosa indica uma mudança na escultura, que marcou a geração de 1960. Assim como os trabalhos de Marcel Duchamp e dos dadaístas, embora estes advogassem uma posição antiestética, alguns trabalhos de construção dos neorealistas franceses e dos neoconcretos brasileiros se distanciavam do conceito clássico de escultura. A apropriação de materiais pré-industrializados e a exposição de objetos achados buscariam propor um pensamento sobre o espaço, que não se pautaria na construção e elaboração laboral do fazer escultórico, tão estimulado nas escolas de Belas-Artes. Há algo de espontâneo, inclusive em objetos do cotidiano elaborados em série, que pode suscitar reflexão sobre o espaço e sobre a vida social. Ainda que possamos entender que algumas obras de Ribeiro passem pela construção elaborada, escultórica, podemos considerar que suas criações estejam mais próximas ao que entendemos como objetos. Entretanto, considerando que o sistema de arte enquanto instituição não acompanha o ritmo dos processos poéticos e das criações dos artistas, percebemos que a crítica de arte dos anos 1960 categoriza as criações de Jackson Ribeiro como esculturas. O sistema de arte da época, principalmente os museus e críticos, usava posturas metodologias formalistas, buscando um racionalismo da arte, interferindo diretamente na compreensão das obras e processos poéticos. As obras de Jackson Ribeiro transgrediam a categorização clássica de escultura, sendo, portanto, objetos de uma abstração poética da forma. Uma experimentação próxima às provocações dos artistas do novo realismo.

Como afirma Pierre Restany (1979, p.33), “o novo realismo preludia um relance geral da arte da assemblage e anuncia, além da superação dos gêneros tradicionais, uma estética do objeto no seu condicionamento espacial” (RESTANY, 1979, p.33). A apropriação da pedra bruta e da sucata de ferro é uma característica fundamental presente nos textos dos críticos da obra de Jackson Ribeiro. Assim, quando Jackson Ribeiro expõe na $6^{\text {a }}$ Bienal de Arte de São Paulo, em 1961, o crítico Pierre Restany conhece a dimensão do trabalho do artista. No Rio de Janeiro, Pierre Restany visitou o ateliê de Ribeiro, acompanhado por Mário Pedrosa, e consolidou uma amizade que resultaria mais tarde na curadoria de uma exposição individual do artista na Galeria Debret, em Paris. Pierre Restany foi um dos pensadores do movimento dos novos realistas, também conhecidos com neorrealistas, com forte atuação em Paris e Nova York. Essa geração de jovens artistas questionou radicalmente os valores não-figurativos, no momento que a arte abstrata parecia ter triunfado. Os anos 1960, em Paris, a atenção era 
voltada para exposições Kandinsky, Mathieu, Vasarely e Soulages. Contudo, para Pierre Restany, essa foi essencialmente uma característica exterior de um contexto da história, o que realmente acontecia era que a vanguarda não se reconhecia "naqueles mestres consagrados que lhe propõem a evasão para mundos imaginários” (RESTANY, 1979, p.23). O movimento dos neorrealistas se transformava, ao passo que os diálogos entre os envolvidos impulsionavam intervenções em salões, mostras e exposições. Foram apresentados ao todo três manifestos dos novos realistas. O segundo, "Quarenta graus acima de dadá", lançado em 1961, revela a postura do grupo diante das possíveis semelhanças com os dadá, entendidos naquele contexto como anti-arte. Os neorrealistas haviam descoberto o folclore industrial contemporâneo e as possibilidades expressivas ligadas ao senso da natureza morta.

Em virtude da curadoria da exposição de Jackson Ribeiro em Paris, Pierre Restany percebeu no trabalho do artista brasileiro as mesmas qualidades que conhecia no grupo, já disperso, dos neorealistas.

"As esculturas de Fernando Jackson Ribeiro possuem o hieratismo enfeitiçante e estranho dos "homens-cactus" de Julio Gonzales. Entretanto sua escala é diferente. Jackson trabalha na massa e na força. Suas combinações de raios metálicos soldados, de emendas de trilhos ou de porcas gigantes dão uma impressão de poder monumental. As formas são simples, e os volumes cuidadosamente controlados.

Uma poesia surda e rouca (como a voz de Jackson) emana de suas estátuasfetiches de nosso mundo industrial.

Jackson conhece bem o metal e os motores, todo este ferro-velho da indústria que não param de fasciná-lo. Eu fui surpreendido na Bienal de São Paulo, em 1961, por suas "estruturas" elementares que unem o metal à pedra, elementos "ready-made" dos motores à pedra bruta ou ligeiramente trabalhada.

Atualmente Jackson não se satisfaz mais em experimentar passivamente a iluminação de suas visões. Ele domina seu trabalho e lhe comunica toda a energia brutal da sua natureza. O "clic" se produz, sem impactos, a corrente passa, a comunicação está livre de qualquer retórica. As esculturas de Jackson são belas porque são fortes, sólidas, cuidadosamente equilibradas. Porque elas estão presentes, pura e simplesmente, e porque ninguém ousaria pô-las em questão" (RESTANY, 1967).

Os apontamentos de Pierre Restany à obra de Jackson Ribeiro orientam-se ao fato do artista integrar fragmentos de objetos do uso comum em um contexto expressionista figurativo. Restany lembra-nos que apropriar-se de fragmentos do real para fins poéticos é 
colocar em questão o problema da autonomia expressiva do objeto, ou seja, retornar ao referente dadaísta, ao ready-made, de Marcel Duchamp: batizar um objeto cotidiano de escultura é efetivamente uma obra de arte na condição em que o artista-inventor assume a responsabilidade moral sobre ela. Nos objetos de Jackson Ribeiro, os fragmentos do real, do cotidiano, são dinamizados em uma escultura totêmica que revela o "folclore industrial contemporâneo" e a transformação do estatuto da obra de arte: por um lado, a construção do objeto ainda permanece ligada a uma linguagem tradicional da escultura, por outro lado sua síntese poética expande a percepção realista, ou seja, Jackson Ribeiro tem uma preocupação de composição e forma, ao mesmo tempo em que cada fragmento do real que ele se apropria já é investido de um potencial de expressividade absoluta. Nesse sentido, os anos 1960 e 1970 na obra de Ribeiro revelam esse caráter de humanismo tecnológico, muito caro aos neorealistas.

A leitura que Restany faz da obra de Ribeiro merece um contraponto com a leitura de Hélio Oiticica, que destaca aspectos estéticos aproveitados com a apropriação de materiais de "usados".

O material com que Jackson as constroem não nos interessa "em si” mas somente na medida em que se relaciona no seu todo e na criação de uma relação significativa primaria. Jackson parte não de "elementos coisas" que são depois transformados, mas de "elementos plásticos" que o atraem "fisionomicamente". Não procura "figuras nesses elementos, mas os fazem tão plásticos como se o fossem. São elementos formais germinativos que ao se juntarem hora em oposições, ora em acumulações como num "totem", criam um espaço coerente total, de acordo com as mais dinamizantes concepções espaciais, característica predominante na escultura moderna" (OITICICA, 1964)

A leitura de Oiticica é efetivamente orientada pela sua experiência com a arte neoconcreta, ele percebe as qualidades plásticas e a elaboração escultórica de Ribeiro. Hélio Oiticica indica as construções de Ribeiro são resultados de uma experiência própria do artista: assim como o artista tem uma "visão fisionômica" sobre cada elemento que usa na construção, ele também tem uma "concepção racional" no que se refere ao espaço escultórico. É importante destacar que o texto de Oiticica, intitulado "Nota sobre a escultura de Fernando Jackson Ribeiro", foi publicado com imagens duas obras de Ribeiro: 


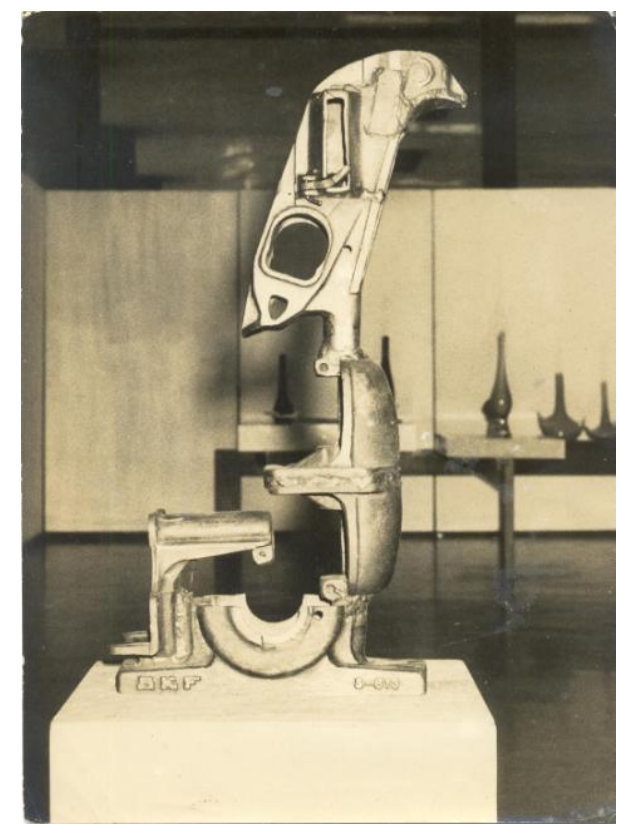

Figura 24 - RIBEIRO, Jackson. Sem título, (1964?). Ferro. Foto: OITICICA, Hélio. Nota sobre a escultura de Fernando Jackson Ribeiro. Rio de Janeiro, 1964. Disponível em: $<$ http://www.itaucultural.org.br/aplicexternas/enciclopedia/ho/index.cfm?fuseaction=documentos\&co d=2\&tipo=2>. Acesso em: 02 jun. 2008.

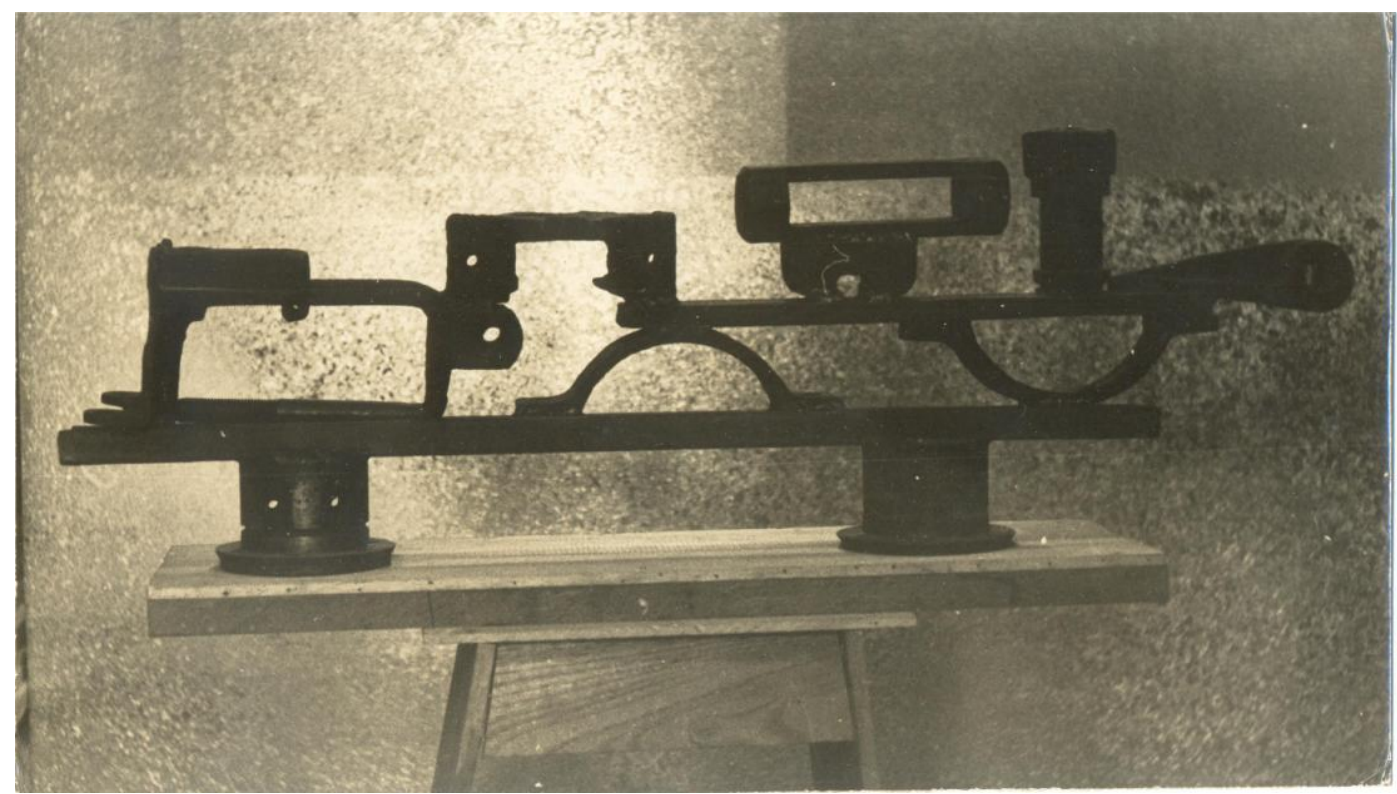

Figura 25 - RIBEIRO, Jackson. Sem título, (1964?). Ferro. Foto: Arquivo do artista (Museu de Arte Contemporânea do Paraná). OITICICA, Hélio. Nota sobre a escultura de Fernando Jackson Ribeiro. Rio de Janeiro, $1964 . \quad$ Disponível em: $<$ http://www.itaucultural.org.br/aplicexternas/enciclopedia/ho/index.cfm?fuseaction=documentos\&co d=2\&tipo=2>. Acesso em: 02 jun. 2008. 
No capítulo 2.1 da nossa dissertação, já indicávamos que os críticos Walter Zanini e Helio Oiticica apontavam o valor poético na seleção dos objetos que compunham as construções de Ribeiro. Os objetos, enquanto elementos plásticos, eram escolhidos pelo artista para a construção da sua linguagem, havia intenção na ação ao passo que Ribeiro através dos objetos expressava um texto particular. Esses críticos combinaram suas reflexões à duas teorias da arte: uma que compreende a obra de arte como objeto de expressão, motivado por um sentimento ou emoção do artista que a criou; a outra teoria orienta-se pela ideia de que a obra de arte corresponde a uma intenção, o que justificaria, por exemplo, a diferenciação entre a obra de arte e um objeto ou coisa comum. Ambos os críticos apontavam um valor intencional presente no fazer artístico de Jackson Ribeiro, Oiticica (1964) afirma, como veremos a seguir, que há uma intenção estética que cerca o desenho escultórico de Ribeiro, algo que se orienta por uma determinada "visualização" de figuras.

\footnotetext{
“Quando determinado elemento “elemento-gérmen” o atrai, já está nesse elemento implícito um determinado sentido espacial que se repetirá nos outros elementos diferentemente, mas semelhantes. O elemento primeiro é, pois o gerador de toda a obra, o "gérmen" dela. Sobre essa totalidade então abre-se a imaginação do espectador que assume aqui papel importante, direi mesmo participante, dentro da obra. Há como que uma "visualização físionômica" do espectador que ora tende à fantasia, ora à visão de figuras, ora à descrição de mitos, etc.” (OITICICA, 1964).
}

A leitura de Oiticica leva-nos a entender também porque esse figurativismo de Jackson Ribeiro se aproxima da fantasia e das imagens míticas populares. O que é interessante é que raramente o artista nomeava suas obras com referência a imagens pré-existentes, pelo contrário, Jackson Ribeiro era tratava sua obra com certa formalidade artística chamando de construções ou elementares e numerando-as como se compusessem uma série. Muitas delas eram batizadas pelos observadores. Assim aconteceu com a construção da alegoria da Mangueira, ou simplesmente Fausto (Fig. 3, p. 27), como foi nomeada pelas pessoas da comunidade da escola de samba. Anos mais tarde, quando Jackson Ribeiro elaborou uma construção de sucata para ser coloca em praça pública em João Pessoa, a localização da escultura (em frente à Faculdade de Filosofia e próximo também de bares boêmios da região central) motivou sua nomeação, popularizada pelo crítico paraibano Vigínius da Gama e Mello como Porteiro do Inferno (Fig. 21, p. 50). Inclusive, sua nomeação garantiu a essa obra pública, um fardo de anos de folclorização e julgamentos "religiosos". Muito antes da 
elaboração do Porteiro do Inferno, Hélio Oiticica já anunciava o problema da mitificação do aspecto totem-folclore da obra de Ribeiro e sua apropriação pela cultura:

Há como que uma transfiguração sucessiva da mesma obra e de seus elementos, que atuam fisionomicamente sobre este espectador num sentido puramente imaginativo. A imaginação parece chegar aqui à identificação mítica coletiva, à redescoberta de mitos latentes na imaginação popular (OITICICA, 1964).

É Hélio Oiticica, crítico, parceiro e amigo de Jackson Ribeiro, quem lhe confere uma leitura panorâmica da sua obra até 1979. Oiticica (1979) pontua as fases de Jackson em uma trajetória familiar, pois havia convivido com o artista desde os 1960. Oiticica percebe a transformação da poética de Ribeiro, quando da geometrização bilateral do objetos feitos durante a residência artística, e da superação do totem-folclore com a criação das decorrências modulares.

\footnotetext{
“Jackson não era 'fabricador de totens': o que regia seu processo criativo (e na verdade agora se floresce-desmembra nas D.M.) sempre foi o principio TOTEM que se liga diretamente à gênese das obras que criou: A descoberta tão rica das D.M. é ao mesmo tempo a fragmentação deste principio-TOTEM e a sua apoteose: TOTEM - MÓDULO - DECORRÊNCIA MODULAR - MULTITOTEM. Não é ciclo, mas decorrência do mesmo principio-TOTEM inicial: as D.M. se abrem para o jogo, a combinação, às decorrências coletivamente descobertas" (OITICICA, 1979).
}

Em 1984, quando Jackson Ribeiro expõe pela primeira vez as Decorrências Modulares no Rio de Janeiro, Frederico Morais escreve que o público concluir apressadamente que o artista estaria se desviando para caminhos racionalizantes. Mas o crítico logo argumenta:

(a obra Decorrências Modulares) serve também para provar que as raízes de nosso construtivismo, brasileiro, latino-americano, podem estar aqui mesmo, e não na Europa e nos Estados Unidos, sociedades afluentes. Ou por outra, as raízes européias são recicladas, aqui, por forças telúricas, por nossos próprios arquétipos (MORAIS, 1984). 
Eventualmente, as soluções chegadas na experiência com os módulos podem recordar telas de um construtivismo de Torres-Garcia, como afirma o Frederico Morais (1984), ou ainda o próprio arcaísmo pré-colombiano. O que podemos perceber é que a obra em si se encerra na participação do público, tanto como agente que cria as soluções quanto como espectador que faz a leitura da obra. Os módulos são o alfabeto que só faz sentido quando combinados entre si, a partir da ação. O argumento de Frederico Morais sobre as raízes de um construtivismo local, reveladas através da interação com as Decorrências Modulares, completa o pensamento de Oiticica de que as decorrências são descobertas coletivas. E, dando prosseguimento a essas experiências de pensamento motivadas pela obra de arte, acreditamos que a ideia de tecido intencional seja a mais pertinente para se compreender o fenômeno que cerca a obra de arte e faz com observadores percebam na obra de arte "raízes" estéticas compartilhadas pelos indivíduos de uma mesma cultura.

A arte revela a dimensão de um fenômeno de comunicação, permitindo que um pensamento ganhe forma plástica na expressão poética e seja, constantemente, revisto e reinterpretado por outros sujeitos, que podem empreender diferentes reflexões a respeito. Sendo assim, A experiência do pesquisador de arte é a de interpretação de experiências: indaga-se um fenômeno que lhe é percebido a partir de uma expressão poética, interpretando seu "tecido intencional" (MERLEAU-PONTY, 1994), ou seja, quais motivações o artista intenciona transmitir. O pesquisador, portanto, percebe algo e, a partir dessa percepção, realiza uma experiência de pensamento no qual o método precisa, antes de tudo, decifrar os códigos da obra de arte, compreender sua maneira de ser, para que ele consiga elaborar uma maneira de traduzir essa experiência e compreendê-la na realidade social da qual faz parte. Perceber é, necessariamente, o exercício de uma experiência que funda um pensamento e, diferente da experiência de um observador desinteressado do mundo social, a experiência do pesquisador é sistematizada dentro da construção de um pensamento (SOARES, 2010, p.340).

A maneira pela qual podemos entender como os objetos despertam novos sentidos em seus observadores seria entender seus códigos, seus signos e traduzi-los como um alfabeto novo, especial, próprio do autor que o construiu. A obra em si sugere caminhos para essas respostas. O material usado e a técnica de Jackson Ribeiro são os elementos mais evidentes para aquela nova língua, seu conteúdo e significado precisavam da interação do observador. $\mathrm{Na}$ fase das construções de pedra e ferro não podemos dissociar esses elementos da realidade social que vivemos e as mazelas de um mundo industrial, cujo modo de produção sujeita o homem à exploração da natureza e ao descarte das sobras da sua transformação. A condição de existência na modernidade, que experimentamos cotidianamente, retorna enquanto reflexão 
diante de um objeto artístico. E quanto mais um pesquisador da obra, um observador, buscar conhecer outros objetos de Jackson Ribeiro e outros objetos que despertassem a mesma temática, sobretudo, entre seus contemporâneos, estaria mais próximo de construir um conhecimento a partir da experiência estética. Esse movimento precisaria da persistência de um método que, sem dúvidas, trataria menos de transcrever que construir uma experiência. Assim, a subjetividade do observador, que se empenha em decifrar os códigos da obra de arte, encontra a subjetividade da obra de arte, cujo objeto permite e convida à experiência do pensar. Se a subjetividade do observador e a subjetividade da obra se comunicam é porque fazem parte da mesma música: e o som do pensamento reverbera entre eles e cria o novo.

É preciso que com meu corpo despertem os corpos associados, os "outros", que não são meus congêneres, como diz a zoologia, mas que me frequentam, que frequento, com os quais frequento um único Ser atual, presente, como animal nenhum frequentou os de sua espécie, seu território ou seu meio. Nessa historicidade primordial, o pensamento alegre e improvisador da ciência aprenderá a ponderar sobre as coisas e sobre si mesmo, voltará a ser filosofia... (MERLEAU-PONTY, 2004, pp.14-15)

Interrogar uma experiência estética é sem dúvida ter uma experiência do pensar. Portanto, interrogar uma criação artística é estar aberto à "experiência não como objeto de pensamento, mas como experiências do pensar" (CHAUÍ, 2002, p.16). Inevitavelmente, a linguagem construirá um vocabulário específico para traduzir esse pensamento, em consonância com os signos que compõem a própria linguagem da obra em questão. As obras de Ribeiro são tratadas como um texto visual e a percepção do observador é um dos elementos fundadores de um significado, também, presente no objeto e despertado pela consciência de quem com ele se relaciona.

O Sentir é esta comunicação vital com o mundo que o torna presente para nós como lugar familiar de nossa vida. É a ele que o objeto percebido e o sujeito que percebe devem sua espessura. Ele é o tecido intencional que o esforço de conhecimento procurará decompor. (MERLEAU-PONTY, 1994, p.84)

Assim, quando encaramos a subjetividade do observador como uma característica fundamental para tradução de sentidos da obra de Jackson Ribeiro, entendemos que essa mesma subjetividade aparece enquanto forma particular necessária na compreensão e interpretação do objeto a partir dos seus códigos, no sentido de habitar sua razão de ser e 
revelar suas estruturas e que a obra de arte ser uma experiência do pensamento. Nesse sentido, as criação imagens míticas e a folclorização da escultura é o resultado do diálogo entre os objetos de Jackson Ribeiro e as pessoas que o vêem. São características tão presentes no objeto quanto no pensamento de quem o vê. Ou, como sugere o poeta Mário Sá-Carneiro,

"Eu não sou eu nem sou o outro, Sou qualquer coisa de intermédio: Pilar da ponte de tédio

Que vai de mim para o outro".

\subsection{Entre o moderno e o contemporâneo: a obra de Jackson Ribeiro como uma vertente construtiva brasileira}

A historiografia da obra de Fernando Jackson Ribeiro é um exercício singular de estudo histórico e crítico acerca da arte brasileira e dos seus historiadores. Esse entendimento acontece em razão de que a arte, como afirma Arthur Danto (1997), é tratada por alguns historiadores como uma narrativa histórica e isso implica fazer escolhas, seleções e construir discursos. Nos capítulos anteriores, esboçamos alguns movimentos e tendências artísticas do século XX, a fim de situar esteticamente e historicamente, a obra de Jackson Ribeiro. Não pretendemos construir um panorama, apenas objetivamos apresentar alguns aspectos que fundamentam o diálogo entre a obra do artista e as discussões que permeavam o circuito de arte no contexto da sua criação.

Consideramos a obra de Fernando Jackson Ribeiro como uma vertente de expressão crítica à modernidade, uma obra que está inserida entre orientações que se dirigem aos aspectos sociais e culturais da sociedade. Tais aspectos precisam ser colocados em suspensão, distinguindo suas especificidades e entrecruzamentos (hibridizações). Sendo assim, percebemos que o conceito de modernidade é entendido como resultado do processo de racionalização que suscitou a modernização social e a modernização cultural. Os aspectos sociais são vinculados a transformação da economia capitalista e da política do estado moderno. Nesse sentido, destacamos que uma sociedade industrial é caracterizada por novas relações sociais. A modernização cultural reflete a racionalização da ciência, da moral e da arte, anteriormente concentradas no discurso religioso. Em outras palavras, o que tratamos como modernidade tem sua origem associada ao surgimento da máquina a vapor, o que 
motivou a instauração do capitalismo e determinada transformação de aspectos econômicos; enquanto na cultura, o conhecimento, a moral e as artes, que estavam em estreita relação com o discurso religioso, passam a sofrer, a partir do século XVIII, determinada transformação motivada pela filosofia das Luzes (ROUANET, 1987).

A modernização social e cultural foi objeto de discussão e crítica entre artistas de distintas tendências, notavelmente dentro dos movimentos realistas e modernistas no final do século XIX e início do século XX. Esse processo de modernização não aconteceu simultâneo nem homogêneo, ele fez parte de uma transformação interna experimentada por cada sociedade no seu tempo. Como observou Aracy Amaral (1990), na América Latina, a modernidade teve a conotação de novo com um sentido de auto-afirmação. Se na Europa, o conceito de "moderno" trazia tácito uma experiência urbana, no Brasil, a emergência da industrialização, acentuou o contato com culturas estrangeiras diversas, alterou significativamente a demografia, notavelmente na região sudeste do país, em virtude do grande fluxo de estrangeiros oriundos de sociedades diferentes das culturas ibéricas e africanas, que já se encontravam presentes no país desde o período da colonização. O tema da modernização social foi, portanto, um importante motivo para o desenvolvimento das poéticas dos artistas brasileiros que vivenciaram essa experiência urbana, influenciados pelas condições econômicas, sociais e políticas do local e do global. Assim, o que alguns historiadores convencionaram identificar como modernismo refere-se, contudo, a uma multiplicidade e heterogeneidade de manifestações artísticas que, por vezes, não se permitem à prisão conceitual cronológica ou geográfica. As vanguardas modernistas, com seu caráter político-identitário, se guardariam por trás de um manifesto e das exposições coletivas. No entanto, diversos artistas, alguns integrantes desses grupos de vanguarda, propunham trabalhos que ora promoviam a extensão do debate ora rompiam com essa ordem, criando uma nova ideia que se apresentava dentro do circuito. Marcel Duchamp se tornaria um artista emblemático para a História da Arte Contemporânea, com uma forte atuação no grupo Dadá e que, despertaria no início do séc. XX questionamentos com uma repercussão significativa na arte dos anos 1950 e 1960.

Seguindo essas orientações constatamos que, para situar a obra de Jackson Ribeiro a partir da contextualização da arte produzida no início do século XX, precisaria circunscrevê-la a partir de suas relações com dois movimentos artísticos emergentes nesse período: o construtivismo e o neorealismo. São dois movimentos que permitem a compreensão histórica da obra do artista e que, certamente, abrem margens para entender as relações de Fernando Jackson Ribeiro com as tendências concretistas e neoconcretas brasileiras. Embora o artista 
não tenha se filiado explicitamente a qualquer movimento ou tendência artística, não convém acreditar que ele tenha se posicionado indiferente ou ignorante ao seu contexto.

Certamente, o construtivismo enquanto movimento não seria um fim para Jackson Ribeiro. Digamos que é possível reconhecer nas suas obras certas proposições de uma arte construtiva, porém isto não quer dizer que se tratava de objetos esculpidos ou trabalhos. Eram construções espaciais elaboradas conscientemente pelo artista, de tal sorte que ele nomeava algumas simplesmente como "construções", seguindo uma numeração. A classificação adotada por Jackson Ribeiro em alguns trabalhos pertencia a um vocabulário abstrato, nãofigurativo. Frederico Moraes, quando escreveu sobre as Decorrências modulares de Jackson Ribeiro, identificou a obra como exemplar do "nosso construtivismo, brasileiro, latinoamericano" (MORAIS, 1984).

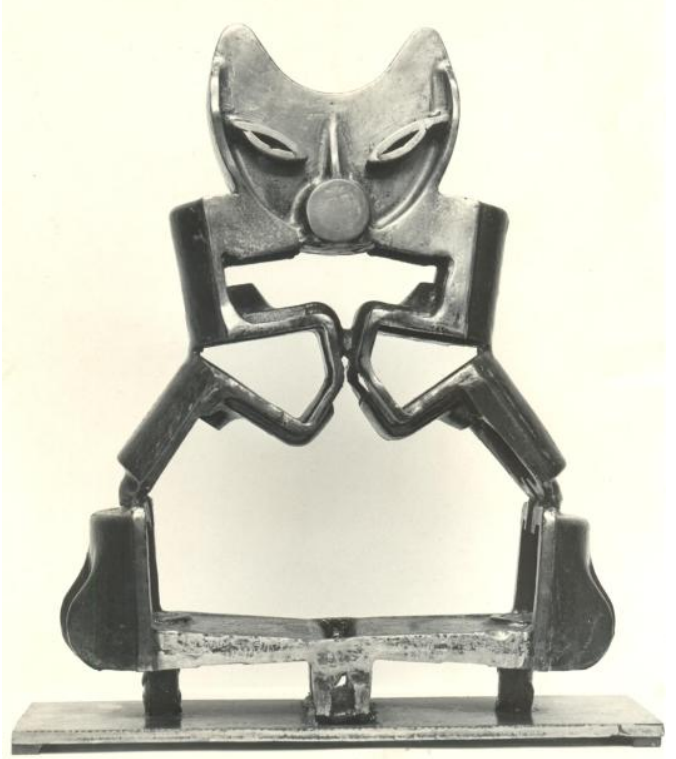


Há em alguns trabalhos de Jackson Ribeiro, notavelmente na Construção 3 (Alumínio, 1972.

Figura 26 - RIBEIRO, Jackson. Sem título, [1968?]. Ferro. Foto: Arquivo do artista (Museu de Arte Contemporânea do Paraná). MAM SP), uma solução criada a partir da construção de um espaço. Esse objeto foi elaborado pela conjunção de formas, tomando tanto a massa quanto o volume espacial como base referencial de leitura e percepção do objeto. Ou seja, se por um lado é possível uma leitura a partir da massa ocupada no espaço construído, também é possível uma leitura a partir das formas vazadas, do espaço cujo volume é reconhecido "internamente". Eis, portanto, algo particular do trabalho de Ribeiro: as formas construídas pela percepção dos volumes (ocupado ou não) assemelham-se às linhas que desenham no espaço, suscitando por sua vez leituras figurativas, sendo difícil em alguns momentos identificá-lo como um artista abstrato ou figurativo.

A obra Construção XIV (ferro, 1968, MAM Rio) é o resultado de uma abstração da forma. Nela o artista executa um estudo do volume aberto, no qual o uso dinâmico do material impede a solução de uma forma estática, o volume é construído pelo desenho da linha, tendo em vista as proporções monumentais do objeto, fazendo com que a massa do ferro pouco interfira na percepção do volume.

Trata-se de um construtivismo particular do artista, que em algumas soluções se remetem a uma figuração geométrica, como é o caso do múltiplo que pertence ao acervo do Museu Casa de José Américo. Basicamente, o artista desenha com a linha uma construção espacial. Reconhece-se o volume, com formas geométricas que, elaboradas a partir de movimentos continuados e interruptos das linhas, criam uma figura. Outro exemplar de uma construção espacial que pode remeter a uma figuração é a obra sem título apresentada na Figura 17. É importante considerar a importância do material na construção do objeto de Ribeiro: são sucatas de ferro, peças pré-elaboradas, cuja forma é apreendida e induzida pelo artista a um novo contexto. Mais adiante trataremos desse aspecto estético, que aproxima sua obra aos neorealistas dos anos 1950. 
Percebemos em toda a obra do artista uma preocupação formal com a massa: a matéria sólida é uma das inquietações do pensamento de Jackson Ribeiro e, sem dúvida, o sentido motivado pelo peso das obras é uma das características que mais desperta uma força expressiva nelas.

É importante ressaltar que o construtivismo realizado por Ribeiro percorre um caminho particular, sem tomar um partido por essa ou aquela tendência artística. Por esse motivo, seria descuidado categorizá-lo em alguma escola, igualmente, poderíamos sugerir sua obra como uma expressão de "arte construtiva", porém cairíamos em um debate estético que não vale a pena investir em si tratando da poética de Jackson Ribeiro. Seus trabalhos são construções e revelam uma experiência individual do artista com objetos descartados.

Quando Jackson Ribeiro apresentou a obra Cristo, no Salão de Arte Moderna do Rio de Janeiro, em 1959, o uso da sucata e a elaboração de construções com

Figura 27 - RIBEIRO, Jackson. Sem título, [1968?]. Ferro. Foto: Arquivo do artista (Museu de Arte Contemporânea soldagem não era algo novo para o circuito de arte. Em do Paraná). 1926 e 1927, o espanhol Júlio Gonzáles, amigo de Picasso, já havia começado a fazer esculturas abstratas com esse material e técnica. Mesmo Picasso trabalharia ocasionalmente com essa técnica (RICKEY, 2002, p. 76).

Em um trabalho referencial para a história da arte no Brasil, Walter Zanini (1983) apresenta algumas "variantes da expressão escultural" nos anos 1960 e 1970. O autor destaca certas "tradições do uso do ferro" em trabalhos de Nicolas Vlavianos, Caciporé Torres e Maurício Salgueiro; o interesse pelo ferro soldado e outros metais distintos do bronze a exemplo de Weissmann. Jackson Ribeiro é destacado pelo autor como um dos melhores escultores da sua geração no Brasil, ressaltando sua obra com o "uso de déchets industriais, também relacionados à pedra bruta, surgiriam as figuras duras e agressivas de contenção formal e embalo totêmico" (ZANINI, 1983, p. 769). O autor propõe que, no meio de variantes materiais e formais, a obra de Jackson Ribeiro se situa em diferentes visões, entre as quais suas imagens sugerem "abstrações do real, perseverando, por outro lado, sistemas específicos de representação antropomórfica" (ZANINI, 1983, p.769). Observamos que, tal como Hélio Oiticica (1964) percebeu, Walter Zanini enfatiza o aspecto "fisionômico" inerente à obra de 
Jackson Ribeiro. Algo que dialoga seu construtivismo com propostas de orientação neofigurativa e neorealista.

Entendemos que as criações artísticas de Jackson Ribeiro, especialmente os objetos os quais o artista utiliza a sucata de ferro e a pedra bruta, situam uma crítica à modernização social e à industrialização. Por se tratar de criações artísticas, sua obra está associada a um desejo de transformação estética, esboçando estruturas e citações da arte moderna. Quando colocamos os aspectos da modernidade e a crítica estética de Ribeiro em suspensão podemos, então, entender os argumentos da sua poética visual. Vejamos essa relação.

Quando entendemos que um dos pilares da modernidade no plano econômico é a industrialização, estamos afirmando que a racionalização da produção industrial sustenta um sistema capitalista. No entanto, se o setor industrial tem se transformado ao longo do tempo, resultando na informatização da sociedade, precisaríamos questionar se este último aspecto caracteriza uma sociedade pós-industrial. O que observamos são mudanças no setor industrial, contudo elas não parecem alterar a estrutura do sistema industrial, pois "pertence à lógica desse sistema o contínuo aumento da produtividade, pela constante redução da mão-de-obra assalariada. A informatização da sociedade torna mais eficiente o sistema industrial, em vez de aboli-lo.” (ROUANET, 1987, p. 259). Dessa maneira, não entendemos que exista uma ruptura com o modo de produção, mas percebemos que há uma relação entre a informatização da sociedade e o declínio do setor industrial. A lógica de uma sociedade moderna não estabelece uma ruptura com a estrutura do sistema industrial. E qual a relação entre a modernidade, a arte e a sistema industrial?

A partir das orientações de Anne Cauquelin (2005, p. 27), observamos que a relação existente entre esses três elementos se revela através do engajamento progressivo do artista no circuito do consumo de massa (ainda que seja para estabelecer uma crítica), a mudança do estatuto do objeto artístico que é cada vez mais compreendido como "produto" e, igualmente, a compreensão do produto industrial como produto estético. A partir dessas orientações, o pano de fundo dessa relação pode ser resumido da seguinte maneira:

Tudo que é produzido deve ser consumido, para ser renovado e consumido novamente. É essa onipresença de consumo que rege a arte moderna, por excesso ou por falta, por adesão ou por recusa (CAUQUELIN, 2005, p.27-28)

Duas observações são importantes para essa reflexão: 
a) Há uma relação estreita entre o que a sociedade atribui como valor a sua produção artística, e a forma como a essa sociedade utiliza essa produção dentro do sistema hierárquico da arte. Assim, o poder de sedução e, portanto, seu valor atribuído tanto para o julgamento estético como para o julgamento econômico, fundamentam a aura da obra de arte, tal como argumentou Walter Benjamin (1999, p. 170)

b) Embora saibamos que a aura do objeto artístico está relacionada a sua circulação no circuito de arte, entendemos que existe uma relação de intersubjetividade entre o artista, a criação artística e o observador. Portanto, entendemos que essa relação de intersubjetividade compreende a historicidade da obra de arte e a experiência que o observador tem com ela. Isso quer dizer que nem a realidade social nem o aspecto econômico são fatores determinantes para a obra de arte, enquanto forma de pensamento e expressão.

Quando situamos a obra de Jackson Ribeiro no contexto da arte no Brasil, entendemos que sua obra revela uma crítica ao sistema de consumo existente na sociedade industrial e à presença do consumo que rege a arte. $\mathrm{O}$ uso que o artista faz da sucata de ferrro, buscando construir sua linguagem, orienta-se no sentido de uma crítica ao descarte, ao consumo e a produção do lixo industrial.

Nesse sentido, entendemos que a primeira fase poética de Fernando Jackson Ribeiro, quando o artista começa a elaborar seus objetos de pedra e ferro, é uma metáfora da lógica interna do sistema industrial: o uso e o descarte. Um fragmento de ferro, sucata de um mundo industrial, quando incrustado sobre uma pedra bruta "gritava" expressivamente uma figura rígida, fria e "fantasmagórica". Esse objeto tem como plano de fundo uma cultura industrial que explora a natureza em função de um sistema de produção econômica. Há na poesia visual de Ribeiro constatação, angústia e denúncia.

Diretamente, seja por seus artistas e membros, seja por seus questionamentos artísticos e filosóficos, duas tendências artísticas dialogaram com a obra de Jackson Ribeiro: o neoconcretismo, "vértice da consciência construtiva no Brasil e a sua explosão", como argumenta Roberto Brito (BRITO, 1999, p. 55), e o novo realismo francês, especialmente o que concerne "um método de percepção e comunicação sensível a serviço de uma intuição cósmica" (RESTANY, 1979, p.30), que exalta um "senso do maravilhoso na natureza moderna, essa dimensão poética latente da realidade ambiental” (RESTANY, 1979, p.32). Tendo em vista esses conceitos gerais dos dois movimentos citados, pretendemos situar a obra de Jackson Ribeiro como uma expressão tangencial a essas duas vanguardas artísticas, 
localizando-a como uma vertente da expressão neorealista dentro de um contexto neoconcreto. De antemão, é necessário justificar por que compreendemos a obra de Ribeiro como expressão neorealista e, para tanto, nos reportaremos diretamente às criações da primeira fase poética do artista que compreendem os objetos de sucata de ferro e a incrustações sobre pedra de mármore. Essa fase inicial de Jackson Ribeiro, considerando sua presença no circuito de arte e seu destaque entre seus contemporâneos, aconteceu durante a efervescência do movimento neorealista na França e seus questionamentos sobre a natureza moderna e a experiência poética na modernidade, enquanto realidade ambiental.

Quando a obra de Jackson Ribeiro emergiu no circuito carioca de arte foi logo percebida por Mário Pedrosa e Pierre Restany. Ambos os críticos construíram relações de proximidade e parceria com o artista. Mário Pedrosa, logo que assumiu o Museu de Arte Moderna de São Paulo, em 1960, anunciou publicamente uma exposição individual de Jackson Ribeiro como um das primeiras exposições da sua gestão a frente do MAM $\mathrm{SP}^{10}$. Embora fosse esperada pelo circuito paulista, a primeira individual de Ribeiro aconteceria somente em 1967 na Galeria Debret, em Paris, sob curadoria de Pierre Restany. Em São Paulo, a obra de Jackson Ribeiro foi conhecida na $6^{\text {a }}$ Bienal Internacional de Arte, onde recebeu prêmio aquisição e foi incorporada ao acervo do MAM SP. Há uma hipótese de que a obra que pertence a Fundação Nemirovisky também tenha sido exposta nessa bienal, tendo em vista que era comum a prática de comércio de objetos expostos nas exposições de arte. Segundo Maria Alice Milliet ${ }^{11}$, o colecionador José Nemirovisky costumava comprar obras expostas em salões e consultava importantes críticos de arte da época como Lourival Gomes Machado, Spanudis e Mário Pedrosa. O nome da obra foi registrado no seu recibo de venda (não datado) como "Elementar 4", com a assinatura de Jackson Ribeiro, que adotava, na época, a grafia do nome Jacson Ribeiro. São fios de ligações entre o artista e o circuito, uma rede que integra críticos, exposições, instituições, marchands e colecionadores. $\mathrm{O}$ envolvimento dos críticos Mário Pedrosa e Pierre Restany foi fundamental para o ingresso da obra de Jackson Ribeiro na instituição e no sistema de arte.

Das relações estéticas entre Jackson Ribeiro e os neorealistas franceses, há uma distinção de citação indispensável: os neorealistas, ao contrário de Jackson Ribeiro, têm em comum o "fato dada" (RESTANY, 1979, p.37), isto é, o ready-made de Duchamp e a colagem de Schwitters. Jackson Ribeiro reconhecia qualidades de volume, massa, cor,

\footnotetext{
${ }^{10}$ Reportagem sobre a nomeação de Mario Pedrosa para direção do MAM SP. "PEDROSA no comando do MAM. Visão, São Paulo, 12 dez. 1960”.

${ }^{11}$ Em entrevista indireta, ou seja, sem captação de áudio ou resposta a questionário. A pesquisadora era a então diretora da Fundação e responsável pela pesquisa da coleção.
} 
tamanho e peso dos objetos, ele trabalhava em um sentido estético, diferente da postura antiestética do ready-made. Ele também soube integrar o objeto existente, uma sucata de ferro ou um fragmento de pedra, a um contexto expressionista construtivo que revelava uma visualidade figurativa ou abstrata. Para Pierre Restany, Jackson Ribeiro criava "estátuasfetiches de nosso mundo industrial" (RESTANY, 1967). O artista lançou mão do objeto industrial para criar objetos artísticos e, de certa maneira, permaneceu ligado a uma linguagem tradicional, como um tipo de síntese poética ou expressionista dos neorealistas franceses. Vejamos a leitura de José Roberto Teixeira Leite (LEITE, 1961, p.115) sobre as relações da obra de Ribeiro e a do francês César:

Completamente diversa è l'arte di Fernando Jackson Ribeiro, « art brut », che ricorda senza alcun dubbio César e che, come quella di César, è impregnata di una vitalità e di una espressione insuperabili. Sia nei raggruppare pezzi inservibili di automobili, trasformati in oggetti del tutto nuovi, pieni di forza, sia nella comunione tra quei pezzi e grandi pietre non lavorate, questo scultore - che fino trent'anni, nella lontana regione dove vivera, non aveva mai visto un'opera d'arte - domina completamente la materia e la tecnica adattandole l'una all'altre in modo perfetto. Di fronte alle sue opere perdono ogni significato domande come “cosa è arte?" e si ha voglia d'indagare, al contrario, su: “cosa non è arte?” (LEITE, 1962, p. 115$)^{12}$.

Peças industriais, somadas a pedra, transformam-se em objetos novos impregnados de vitalidade. Essa vitalidade é o sopro de vida que o artista dá às sucatas de ferro com as quais trabalha. A síntese poética de Ribeiro situa-se em certas preocupações tradicionais de composição, volume, cor e massa, associadas a "passagem do folclore industrial à estética do objeto, do advento de um senso moderno da natureza" (RESTANY, 1979, p.38). Assim como os neorealistas franceses a obra de Ribeiro aparece como uma reação não conformista ao

\footnotetext{
12 "Completamente diferente é a arte de Fernando Jackson Ribeiro, "art brut", que recorda César, sem qualquer dúvida e que, assim como César, está impregnado de uma vitalidade e uma expressão insuperável. Ambas as peças combinam para uso em automóveis, transformados em objetos totalmente novos, plenos de força, tanto na comunhão entre as partes e grandes pedras não trabalhadas, este escultor - que até três décadas na longínqua região onde vivera, nunca tinha visto uma obra de arte - domina completamente o campo e as técnicas e adapta uns aos outros de modo perfeito. Em face de todas as suas obras perderem significado pergunta como "o que é arte?” E queremos investigar, ao invés, sobre “o que não é arte?” (LEITE, 1962, p.115).
} 
abstracionismo, há no seu método ação e sensibilidade em direção a um "aparente" humanismo do objeto. Todavia, bem mais que a idéia de humanizar o objeto, a criação de Jackson Ribeiro revelava um ser cuja realidade não se esgotava nas relações exteriores e só poderia ser compreendido a partir de uma abordagem do fenômeno.

Certamente, essa seria a característica mais evidente da aproximação da obra de Ribeiro ao esforço do movimento neoconcreto. Por outro lado, sua obra também revelava questões inerentes ao debate dos novos realistas franceses, inclusive essa aproximação é sugerida pelo crítico Pierre Restany. Não podemos nos refutar que a historicidade do processo poético de Jackson Ribeiro emerge como um vértice entre o moderno e contemporâneo, e nesse terreno estabelece um diálogo com dois movimentos da vanguarda artística. Nesse sentido, consideramos importante encarar a obra de Jackson Ribeiro como elemento indispensável para compreender o aparecimento e o desenvolvimento desses movimentos artísticos, assim como seus desdobramentos naquilo que se convenciona trata como Arte Contemporânea.

\section{O SOCIAL E O SENSÍVEL}

Certas orientações de objetividade nas ciências humanas e sociais consideraram que o observador é o intérprete da obra de arte, e que existe um "contexto" que conecta as coisas do mundo e precisa ser decifrado. Essas convenções vacilam na busca de um distanciamento impossível de compreender a obra de arte. Quando nos propomos a compreender a obra de Jackson Ribeiro, necessariamente, pretendemos habitá-la e compreender sua razão de ser. Isso quer dizer que recusamos forjar métodos e técnicas de apreensão de algo que nos convida à experiência do olhar, um olhar que está no mundo. Aquele que observa, também identifica e reconhece aquilo que é observado. É vidente e visível. E, embora a primeira experiência tenha sido aparentemente realizada pelos sentidos, como simples exterioridade, entendemos que existem elos que se constroem cada vez que o observador se relaciona com a obra de arte. Nesse processo, o que é mais importante é encarar a experiência e dela perceber suas qualidades e sentidos. Assim, intencionamos um pensamento de ciência que se distancia da costumeira categorização, pois não pretendemos enclausurar um processo poético dentro de um "fazer ciência" artificial, que opera modelos ao invés de compreender o fenômeno. Nesse momento é o observador quem experimenta, descreve e reflete a obra, e ao fazer uma reflexão, necessariamente, ele realiza uma auto-reflexão. Ao passo que construirmos um 
pensamento sem lidar com a hierarquização dos sujeitos, - artista, criação, observador, - nos permitimos realizar uma experiência intersubjetiva na qual os sujeitos integram uma mesma realidade. A distinção dos sujeitos é um recurso que o cientista busca para, dentro de um vazio, um não-saber que deseja saber, se distanciar do objeto de pesquisa e transformá-lo em objeto de pensamento. $\mathrm{Na}$ verdade, tanto o observador quanto o observado fazem parte do mesmo mundo e é justamente esse elo que permite ao observador compreender o que ele observa. Ambos integram a mesma paisagem e, portanto, a compreensão que um sujeito tem a respeito de uma coisa reflete um reconhecimento que o sujeito tem de si mesmo. "Não tenho medo nem de chuvas tempestivas nem das grandes ventanias soltas, pois eu também sou o escuro da noite" (LISPECTOR, 1998, p. 27).

Fundamentalmente, nossa reflexão crítica questiona três conceitos estabelecidos: 1) o artista como criador, 2) a obra de arte como criação e 3) o observador como contemplador. Para além dessa condição preliminar, entendemos o artista como um sujeito que vive experiências que lhe motivam à criação, e dessa forma sua criação também é a expressão de suas experiências: e a criação artística é o aquilo que está no mundo e que sempre nos convida às novas experiências. A criação artística convida o observador a um contato interior, por meio da experiência de se sentir no mundo como um sujeito que percebe e pensa: "Pensar é um ato. Sentir é um fato (...) a verdade é sempre um contato interior e inexplicável” (LISPECTOR, 1998, p. 11). Por sua vez, o observador, este sujeito que na condição de pensador costuma ser entendido como o sujeito absoluto da ação, que é entendido pela ciência clássica como aquele que define o objeto de conhecimento e, por isso, é o agente do conhecimento. Como observador, nós nos compreendemos integrados a um mundo onde vivemos, sentimos e temos uma experiência que é margeada por outras possibilidades de experiências, que são chamadas a se realizar a cada novo olhar que lançamos à criação artística. Este observador busca conhecer, compreender e refletir a própria experiência como algo que integra uma totalidade, e que se conhecendo, se compreende e se reflete. Assim, longe de entender meu corpo enquanto uma máquina que observa e tira conclusões sobre o mundo, tal como um processo de informação que toma dados acerca de um objeto artístico, objetivamos ter experiência com a obra de Jackson Ribeiro e, dessa maneira, também, realizar nossa experiência de pensamento. Consequentemente é deste modo que entendemos nosso trabalho no estudo a partir da obra de Jackson Ribeiro, e compartilhamos da compreensão de Merleau-Ponty quando argumenta que o movimento de aproximação da obra de obra é uma experiência de percepção. Vejamos essa citação abaixo: 
Imerso no visível por seu corpo, ele próprio visível, o vidente não se apropria do que vê; apenas se aproxima dele pelo olhar, se abre ao mundo. E esse mundo, do qual ele faz parte, não é, por seu lado, em si ou matéria. Meu movimento não é uma decisão do espírito, um fazer absoluto, que decretaria, do fundo do retiro subjetivo, uma mudança de lugar milagrosamente executada na extensão. Ele é a sequência natural e o amadurecimento de uma visão. Digo de uma coisa que ela é movida, mas, meu corpo, ele próprio se move, meu movimento se desenvolve. Ele não está na ignorância de si, não é cego para si, ele irradia de um si... (MERLEAU-PONTY, 2004, p.16).

Toda vez que nos deparamos com uma obra de Jackson Ribeiro, a experiência é sempre nova e diferente, embora entendessem que existe um elo familiar desde o primeiro encontro. Nós conseguimos perceber o objeto através do contato visual, e nosso olhar é amadurecido a cada nova experiência com esse objeto. E no exercício de descerrar o véu do comum, do acostumado, do corriqueiro, e quando passamos a propor desalinhar um pensamento que cerque a experiência de olhar a obra de arte, entendemos que nosso corpo se orienta por um diálogo íntimo com a própria obra de arte. Estamos no mesmo mundo e nos reconhecemos por afinidade, quando a obra de arte nos faz refletir através das semelhanças, ainda que memorial. Quando entendemos que esta experiência, por sua vez, pode ser inteligível a outras pessoas, construímos o projeto dessa pesquisa.

Quando pensamos em dar inteligibilidade a essa experiência, organizamos nosso trabalho seguindo uma seqüencia de estudos realizados a partir da obra de Fernando Jackson Ribeiro. Primeiramente, descrevemos os aspectos que constituem a obra do artista e reconstituímos seu cenário de produção e circulação, contextualizando historicamente. Assim, objetivamos situar a recepção da obra no seu contexto de exposição a fim de somar informações para subsidiar a análise que empreenderemos em seguida. Para dar inteligibilidade a poesia visual de Ribeiro, sistematizamos suas obras, reunindo-as por fases poéticas, a fim de realizar um exercício de conhecimento a partir da visualidade da obra (ARANHA, 2008). Tal como nos exercícios sugeridos por Aranha (2008), que se orientam por uma experiência fenomenológica do olhar, observamos obra por obra, uma após a outra, reconhecendo suas semelhanças e diferenças, mas, sobretudo, reconhecendo o fio condutor de um pensamento-ação do artista que, ao se tornar visualidade, nos comunica e nos despertar os fios condutores de um novo pensamento.

Nos capítulos anteriores, damos indícios sobre o fenômeno percebido, uma realidade interna, que ora tratamos como um ele entre o social e o sensível e agora que nos propomos a 
esmiuçar. Nos próximos capítulos, podemos examinar melhor a obra do artista dando continuidade a nossa experiência de pensamento. Para a análise do fenômeno, partimos de dois conceitos fundamentais: primeiramente, a realidade que entendemos como social e sensível surge a partir de um "impensado" (MERLEAU-PONTY, 1943), que é inerente à obra de arte; entretanto, este "impensado" torna-se inteligível somente através da experiência de pensamento que realizamos (CHAUí, 2002).

Por fim, trataremos de identificar o fenômeno e descrever as tramas que cercam sua manifestação. E, para tanto, esse capítulo tratará desse elo entre o social e o sensível, assim como problematizaremos as relações intersubjetivas (artista/obra-de-arte/observador) que fundamentam a experiência de pensamento fenomenológico.

\section{1 "Uma poesia surda e rouca": visualidades como experiência do olhar}

Quando observamos pela primeira vez um objeto de Jackson Ribeiro adentramos um universo particular, nossa porta de entrada, ou melhor nosso porteiro, foi uma escultura singular: Porteiro do Inferno, uma obra pública instalada na cidade de João Pessoa. Ao primeiro olhar, questionávamos quanto o material, seu emprego, suas formas e soluções plásticas, mas, sobretudo, buscávamos entender a força, a experiência do corpo e da alma, do artista que deixou naquela criação as marcas da sua vivência. Foi a partir da expressão artística que chegamos ao paraibano Fernando Jackson Ribeiro, um artista cuja obra marcou a história da arte em um período quando as ideias e os conceitos caminhavam no sentido de entender e dialogar com os questionamentos da arte contemporânea.

Quando estabelecemos o recorte dessa pesquisa, consideramos o processo poético de Ribeiro como uma construção de uma linguagem artística em diálogo com o mundo em que vivia, e que se revelava em visualidades (ARANHA, 2008, p.15). Isso quer dizer que a obra de arte de Jackson Ribeiro também é a expressão de como o artista percebia o mundo em que vivia, como percebia a dinâmica social a qual fazia parte e as tramas sensíveis nas quais estava envolvido: ou seja, como seu olhar foi educado de tal maneira que refletiu nas suas criações.

No capítulo "Aproximações e contaminações entre artes visuais e design", defendemos que o processo poético de Jackson Ribeiro realiza uma história da forma. Ou seja, cada fase poética de Ribeiro revela uma maneira como o artista lançou mão de um conhecimento sobre a forma. Entendemos o processo poético do artista em duas fases que 
marcam períodos distintos da sua produção: a primeira seria quando artista experimenta construções totêmicas com a pedra e o ferro, ou somente com o ferro, e a segunda fase é a criação das Decorrências Modulares e o seu desencadeamento com diversos suportes. Desde os primeiros trabalhos, Jackson Ribeiro desenvolve uma estética particular, o artista tem uma preocupação quanto à forma e o volume do material que se apropria. Se na primeira fase, quando o artista dinamiza o uso da sucata de ferro, seja na incrustação sobre a pedra, seja incrustação de outros pedaços de sucata, sua criação se orienta a partir da forma dos objetos.

Em diversas entrevistas, Jackson Ribeiro expôs sua inquietação quando estava criando um objeto. $\mathrm{O}$ artista visitava casas de ferro velho, onde poderia comprar sucata aos quilos e depois levar ao ateliê e viver a angústia da nova escolha das formas. Jackson Ribeiro vivia dia após dia examinando peças e selecionando-as, construía em sua memória um arquivo da forma de cada pedaço de ferro. Havia nesse processo uma relação entre a percepção visual da forma dos objetos e um sofrimento motivado pela escolha de uma peça principal, um objetogérmen, que daria origem a uma construção. Essa relação de sofrimento, tal como era descrita pelo artista, se dava pelo fato de que em algum momento o artista precisaria realizar a escolha de alguns objetos pela sua forma e não aproveitaria toda a sucata, que já lhe representava aquilo que foi descartado, aquilo que era sobra ou lixo de uma sociedade industrial que constrói máquinas e as descarta após o uso. O artista acreditava que suas criações eram uma maneira de humanizar a máquina, e de certa maneira quando ele apreendia as formas do ferro pré-industrializado e elaborava construções, ele dinamizava o espaço escultórico e criava algo novo. Nesse sentido, o artista tornava visível sua sensibilidade, seu encantamento pela sucata, seu sofrimento na seleção das peças e, sobretudo, sua crítica social.

$\mathrm{Na}$ primeira fase do processo poético, Jackson Ribeiro juntava um monte de ferro velho e, a partir da percepção das formas dos objetos, ele criava obra de arte com uma carga expressiva de vida, um potencial de vitalidade única. Para o artista, tudo partia de uma crítica à cultura do consumo, como se vivêssemos em um tempo em que criamos máquinas para nos servir e quando elas não nos fossem mais úteis bastaria somente descartá-las. Com a intenção poética de Jackson Ribeiro, a máquina ganhava uma vida eterna ou um eterno retorno à vida, pois da sua sucata algo novo surgiria, algo que pudesse enaltecer aquilo que lhe resta: sua forma. E do lixo - como das cinzas, revirado e selecionado, renasceria um ente que emitiria um grito de vida - tal como uma fênix. Quando Pierre Restany escreveu o texto de apresentação da exposição individual de Jackson Ribeiro, em Paris, afirmou que "uma poesia surda e rouca (como a voz de Jackson) emana de suas estátuas-fetiches de nosso mundo 
industrial” (RESTANY, 1967). A poesia de Ribeiro se transforma em visualidade nas suas construções, e essa visualidade advém da experiência de uma experiência sensível do olhar.

A experiência de olhar, de perceber as formas de um objeto de Jackson Ribeiro, é um encontro com um invisível que é só possível na experiência com a obra de arte. Seguindo o argumento de Carmen Aranha (2008, p.15), entendemos que a construção da expressão criadora de Jackson Ribeiro tem sua gênese no seu olhar que vê o mundo e interpreta-o com a lógica que lhe é própria. Quando o artista iniciou suas incursões no campo escultórico ele passou a indagar seu mundo e elaborar tentativas de interpretá-lo através de construções de objetos feitos com a sucata de ferro e a pedra. E a escolha desses elementos não aconteceu por acaso, Jackson Ribeiro contava que a paisagem sertaneja da Paraíba e a paisagem das pedreiras do cerrado em Mato Grosso lhe marcavam a memória. Nesse sentido, as indagações de Jackson Ribeiro revelam o invisível como estofo, forro, avesso, polpa do visível, trata-se de um invisível sensível por seus aspectos sociais. Nesse sentido, a obra do artista é uma experiência que faz interface entre o social e o sensível.

\subsection{O social envolvido pelo sensível ou uma construção metodológica de compreensão da obra de arte}

Antes de avançarmos, é importante definir claramente em qual sentido empregamos o termo sensível nesse estudo, ou melhor, em qual sentido do termo nos aproximamos para realizar nossa experiência de pensamento.

Embora saibamos que o termo sensível é polissêmico, nesse estudo circunscrevemos o sentido de designar a "vida das sensações" (LAPLANTINE, 2005a, p. 100), isso quer dizer, as relações que temos com os sons, com os odores, os sabores, as percepções visuais e táteis. Essa definição nos remete diretamente a um embate entre o racionalismo e o empirismo. Uma atitude racionalista ou intelectualista, sem negar que existe dados da experiência sensível, se preocupa essencialmente do que os organiza. Dessa maneira, acredita-se que é a ordem da razão que faz aparecer uma inteligibilidade escondida atrás de uma aparente desordem de sensações e de emoções. É como se na polissemia do termo sentido, designando por vez o sensível e o sentido, a sensação e o significado, o racionalismo estivesse fadado a sempre resolver um problema. Essa tradição de hierarquizar o sensível e o inteligível é estranha ao pensamento artístico de muitos artistas brasileiros que atuaram nos anos 1960, e isso é notavelmente percebido no processo de Jackson Ribeiro. 
Por um outro caminho, uma atitude empirista pode incorrer nas certezas imediatas do que nós percebemos: imagens, sons, odores sabores e texturas. Entende-se como uma evidência do sensível, ou melhor, como uma impressão de evidência, que é uma presença no mundo, consigo e com outros. Essa impressão de evidência se confunde com o sentimento de viver. É uma experiência ordinária da vida cotidiana, irrefutável ou ainda que não teria muito a dizer cientificamente.

Não refutamos absolutamente a maneira como essas correntes de pensamento entendiam o sensível e como relacionavam o social. Merleau-Ponty (1972, p.401) ao pensar a história da filosofia já indicava que "não há uma filosofia que contenha todas as filosofias, em certos momentos; a filosofia está inteira em cada uma delas. Para retomar a expressão famosa: seu centro está em toda parte e sua circunferência, em nenhuma". Todavia, a maneira como entendemos as relações entre o social e o sensível se aproxima de uma postura que busca cercar o fenômeno e ousa experimentá-lo, ainda que através do pensamento motivado por uma criação artística.

A percepção acerca da hierarquização do social e do sensível na filosofia também reflete no pensamento das ciências humanas e sociais, que tivemos contato na nossa formação. As ciências humanas e sociais sempre trouxeram um questionamento metodológico sobre a postura do pesquisador em relação ao seu objeto de pesquisa. A orientação positivista nessas ciências propõe um distanciamento, no qual as questões empreendidas pelo pesquisador serão objetivadas a partir de uma determinada "neutralidade científica". Essa metodologia deveria ser empreendida sem que houvesse uma confusão entre a subjetividade do objeto de estudo e a subjetividade do pesquisador. O pesquisador, no seu terreno de estudo, seria motivado por um método neutro capaz de analisar um fenômeno sem que seu envolvimento com o objeto enfraquecesse seu discurso. As questões que propomos discutir aqui estão ligadas a nossa experiência, em particular, ao estudo da produção escultórica de Fernando Jackson Ribeiro. Nesse terreno, lidamos com o sensível e, especialmente, com a experiência do pensamento a partir do diálogo com um processo poético, indagando-o e interpretando-o, sem que isso seja um exercício de apropriação que busca explicações definitivas. Duas questões apresentam-se fundamentais para essa discussão: a pesquisa em arte pode revelar uma objetividade específica? E, no caso de uma pesquisa dentro das ciências humanas, há lugar para a subjetividade do pesquisador?

O objeto de estudo nas ciências humanas e sociais tem uma característica bem específica. Ele é o resultado da percepção da realidade a partir do olhar do pesquisador, este que desenvolve métodos e técnicas para entender o fenômeno que envolve seu objeto. Em 
ciências sociais, há um questionamento metodológico clássico que pretende entender se o objeto de pesquisa social é o resultado de uma construção científica ou de uma constatação da realidade (BOURDIEU, 1984, p. 86-87). Porém, o objeto de estudo em ciências sociais é situado em um conjunto de experiências que dialoga a partir de uma determinada realidade. Percebemos o mundo em que vivemos e dialogamos experiências; algumas delas passam por um exercício do pensamento científico que buscará, metodologicamente, entender como o aquilo que é percebido é, também, inteligível e pode ser compreendido enquanto tal. O objeto das ciências humanas e sociais não pode ser apenas uma constatação da realidade, pois o que eu constato faz parte de uma subjetividade própria da minha experiência; logo a minha constatação é parcial, ou seja, ela tem seus limites enquanto leitura subjetiva, particular. Podemos entender que a constatação é uma etapa que, orientada por uma elaboração metodológica, passa a construir um objeto de questionamento que faz parte da realidade do pesquisador, embora seja uma realidade em suspensão. Nesse sentido, a questão dicotômica constatação/construção do objeto, em ciências humanas e sociais, acaba sendo um impasse de uma interpretação positivista que, desse modo, parece estar mais preocupado em exteriorizar uma experiência do pesquisador separando desdobramentos que estão concatenados, sem entender essa experiência como parte de uma realidade da qual o pesquisador faz parte. Um fenômeno percebido no seio do cotidiano do pesquisador é visto, tocado, ouvido, enfim, todo o percebido já é em si um movimento de um pensamento sofisticado, de uma abstração da sua realidade (SCHUTZ, 1987, p. 8). Sendo assim, a escrita acadêmica é uma elaboração linguística dessas experiências no social e, portanto, as palavras são pesquisadas para mostrar ao leitor aquilo que eu percebo, caracterizo e construo a cada vez que vejo (LAPLANTINE, 2005b).

A arte está no terreno do social, logo é sensível e motiva experiências. Ela se realiza a partir de expressões da linguagem, codificadas a sua maneira, e seus signos dialogam com as realidades do artista e dos observadores. Assim, quando um pesquisador coloca em suspensão uma criação artística ou um processo poético, para realizar um estudo científico, ele já realiza uma abstração da sua realidade. Isso quer dizer que apreendemos alguns aspectos sob um ponto de vista, uma subjetividade específica, que constrói procedimentos metodológicos ancorados em um pensamento maior.

Não seria absurdo pensar em termos sociológicos que o fenômeno social carrega também a capacidade de ser sensível, no sentido de ser percebido por alguém. Certamente, ouviríamos alguns cientistas sociais tratarem esse aspecto como constatação, e comumente 
diferenciando-a do caráter de construção científica que também é atribuído ao ofício do cientista que percebe o fenômeno.

Nossa experiência a partir obra de arte de Jackson Ribeiro nos revelou algo que foi também possível perceber através da experiência com a obra de arte de outros artistas. Talvez com um objeto conhecido ou mais, porém com uma potencialidade universal. Em Jackson Ribeiro, pudemos conhecer um número significativo de criações e perceber a recorrência de uma vontade de comunicar socialmente. É como se o social e, aqui me refiro a um social atrelado à ideia de modernidade e à industrialização da sociedade, estivessem envolvidos por uma carga sensível e poética, e, portanto, também sujeito à percepção de alguém.

O termo "social" atrelado à ideia de modernidade e a industrialização pode ser encarado como amplo ou vago, se nos detivermos a uma determinada incursão ou postura sociológica. No debate sociológico, o termo "social" é algo problemático porque pode abarcar diversos fenômenos emaranhados entre conceitos e teorias. Mas a discussão que nós propomos está no nível de dissertar uma ideia e não desenvolver uma tese, assim a escolha de um aspecto do termo "social" é uma tentativa de introduzir um diálogo filosófico que possa cercar a experiência de pensamento que temos com a obra de Jackson Ribeiro.

Dizíamos acima que percebemos que a obra de Jackson dá pistas de um social envolvido pelo sensível e que isso se revela nos objetos do artista como poesia, ou melhor como um processo poético que insiste em ser expressão. Como isso ganha visualidade na obra do artista? Pensemos na sucata industrial e no emprego que o artista lhe dá. Em tantas entrevistas, é reincidente seu objetivo. A beleza do lixo, da sucata de ferro, do descarte industrial das formas que lhe chama a atenção. O artista vê beleza e forma, e, portanto, sua obra caminha a um sentido estético. E se trata de um formalismo particular da sua percepção e do uso e manejo que se revela do material na sua criação. $\mathrm{O}$ artista não está alheio ao mundo em que vive. A escolha do material carrega uma postura social crítica com uma carga poética única, sensível em cada objeto que nos convida o olhar. Em entrevista, Jackson Ribeiro afirma:

\footnotetext{
"Eu queria trabalhar com o lixo, mas queria um lixo que não acabasse rapidamente, demorasse um pouquinho, deixasse o recado. E veio ai o trabalho de sucata. Ferro velho mesmo, que eu guardava para construir máquinas de tornear moldura (...) Meu desenho foi evoluindo e já me permitia viajar mais na escultura até entrar neste sistema modular, que faço hoje e vou continuar fazendo até morrer. É a decorrência modular, a geometria que acho natural”. (LOPES, 1988, p. 6)
} 
Percebe-se que a preocupação formal do artista é evidente. Isso orienta seu processo poético desde as primeiras experiências com a sucata até a criação das decorrências modulares. Mas, como já tratamos nos capítulos anteriores, quando consideramos o material empregado, situando a produção do artista no contexto de desenvolvimento tecnológico da industrialização à informatização, entendemos o que desperta atenção da crítica de arte quando surgem os objetos de Jackson Ribeiro.

Mas quando nos aproximamos da obra de Jackson Ribeiro, nosso pensamento já busca construir uma metodologia capaz de compreender a obra de arte, dessa maneira queremos responder a questão introdutória desta dissertação: como são construídas e como são dinamizadas as relações intersubjetivas artista/obra de arte/observador, ou melhor, Jackson Ribeiro/social-sensível/pesquisador?

A experiência com a obra de arte é uma experiência de momento. Para o artista, essa experiência se deflagra no instante em que a poesia torna-se ato criativo. Para quem observa e experimenta a criação artística, que é naturalmente a expressão artística de outra pessoa, a experiência com a obra de arte se dá no momento em que se observa e se percebe aquilo que não se tinha percebido antes. Por isso, compreendemos a obra de arte como uma experiência contínua, permanente, tal como uma experiência de pensamento. Disse o poeta:

\author{
"Sei ter o pasmo comigo \\ Que tem uma criança se, ao nascer, \\ Reparasse que nascera deveras... \\ Sinto-me nascido a cada momento \\ Para a eterna novidade do Mundo" (PESSOA, 2005, p.19)
}

O estudo de um processo poético fez com que nosso olhar fosse constantemente renovado. Todo contato que tivemos com os objetos de Jackson Ribeiro era uma novidade particular a cada momento. Portanto, seria difícil pensar na obra de arte e sistematizá-la a partir de uma percepção de momento. A obra de arte não permite que o pesquisador congele uma experiência que se refaz frequentemente. A obra de arte como obra de pensamento não está sujeita à posse intelectual, essa premissa é nossa constatação maior, nos orientou a experimentar a obra de arte sem preconceitos e fundamenta toda nossa pesquisa. Buscamos nos orientar pela advertência de Marilena Chauí (2002), 
tem como condição e cativeiro do mundo na identidade do costumeiro" (CHAUÍ, 2002, p.135”).

Para nos aproximar do fenômeno que entendemos como a relação entre o social e o sensível, orientamo-nos pelo método interpretativo. Seria necessário menos explicar o fenômeno, que identificá-lo e compreender sua manifestação. Partimos do entendimento que os fenômenos sociais, os discursos e as instituições, existem independentes da nossa percepção. Eis, portanto, a característica de constatação que recai sobre os estudos sociológicos. Por outro lado, quando identificamos tal fenômeno, esta identificação já é uma abstração da realidade, está nesse momento em uma relação íntima com a percepção de mundo de quem a percebe. Tanto o fenômeno percebido quanto quem percebe faz parte do mesmo mundo, são integrantes de uma mesma realidade e naturalmente se confundem.

Quando discorremos a respeito do social e do sensível na obra de Jackson Ribeiro, estamos realizando nossa leitura do texto visual criado pelo artista. A obra de Jackson Ribeiro, tal como percebemos, se apresenta como uma combinação de signos, ajustados, arranjados com uma determinada ordem, própria do seu processo poético. A pedra, o ferro, ou ainda a geometria das combinações dos materiais e o movimento revelado, são as cifras da expressão do pensamento do artista. E, portanto, essa escrita codificada, revelada durante a construção da linguagem do artista, encontra na escultura e no objeto seu deslanche. Considerando a experiência com as decorrências modulares, a construção da linguagem de Jackson Ribeiro deixa o registro de sua inquietação com o problema do espaço (a partir da tridimensionalidade) e da industrialização da sociedade (social/sensível). Entretanto, essas considerações que afirmamos só reforça a crença em uma linguagem das coisas, como se a expressão artística de Ribeiro fosse uma melodia familiar. A obra de arte enquanto obra de pensamento encontra sua máxima quando seu receptor atribui significação aos signos percebidos. Vejamos o que afirmou Merleau-Ponty a esse respeito:

\footnotetext{
"O pensamento se sabe e se basta; ele se notifica exteriormente por uma mensagem que não o contém, e que é capaz de ler a mensagem porque ele atribui, pelo efeito de uso, das convenções humanas ou de uma instituição divina, a mesma significação aos mesmos signos", afirmou (Merleau-Ponty, 2012, p. 35)
}

Quando nos orientamos por um método interpretativo da obra de arte, não objetivamos a significação absoluta da coisa, mesmo por que nem a obra de arte nem a experiência que temos com ela permitem essa possibilidade. A interpretação, isso quer dizer, a leitura que 
realizamos, é uma experiência de compreensão da obra de Jackson Ribeiro. E, nesse sentido, quando nos aproximamos da linguagem do artista, nosso objetivo está mais próximo à postura fenomenológica do retorno às coisas. Naturalmente, nos deparamos com a conotação que Husserl atribuiu inicialmente à fenomenologia, tratando-a como descrição e se opondo à ideia que as coisas são o resultado de múltiplas causalidades. As esculturas e objetos de Ribeiro já existiam antes de nos depararmos com elas e, portanto, o estudo que empreendemos nada mais é que o esforço de dar inteligibilidade a uma experiência, motivada pelo reencontro com um pensamento, expresso e motivado pela obra do artista. Ou seja, descrevemos nossa experiência tal como compreendemo-la, em uma relação estreita entre a dinâmica social e a maneira como a percebemos - o social e o sensível. Se desejamos dar inteligibilidade a nossa experiência com a obra de arte é por que as questões levantadas, as qualidades e os sentidos identificados residem mais em nossa experiência que nos objetos artísticos. A leitura do processo poético de Jackson Ribeiro tornou compreensível que a experiência com a obra de arte não é o produto de relações de causalidade - este é o mais importante aspecto que carregávamos de uma formação acadêmica enraizada nas orientações das ciências modernas. Em outro aspecto, nossa experiência de pensamento, motivada pela leitura do processo poético do artista, nos faz redescobrir uma dimensão a qual nos situamos como "ser no mundo" (Merleau-Ponty, 1945, p.11). E, nesse momento, o método que desenhamos nesse estudo não desejou "romper" ou renunciar as amarras que liga o pesquisador ao mundo, tão pouco converteu uma certeza do mundo em uma certeza de um pensamento que temos à respeito do mundo. O método define seu principal objetivo em colocar essa experiência de pensamento em suspensão, e tornar evidente o que lhe é estranho e paradoxal.

Como em toda pesquisa acadêmica, o estudo de um processo poético ou uma obra de arte possui seu objeto, método e qualidade específicos. A natureza do nosso objeto nos dá respostas às nossas indagações a partir da nossa experiência de pensamento, conforme nosso enfoque epistemológico. O estudo de um processo poético é um estudo da experiência, e, portanto, das qualidades e sentidos que são percebidos dessa experiência. Assim, a qualidade é uma propriedade do objeto de pesquisa, a obra de arte, que percebemos quando dela temos experiência.

"Ver é ter cores, ou luzes, ouvir é ter sons, sentir é ter qualidades, e, para saber o que é sentir, não bastaria ter visto o vermelho ou ouvido um lá - o vermelho e o verde não são sensações, são sensibilidades, e a qualidade não é um elemento da consciência, é uma propriedade do objeto". (MERLEAU-PONTY, 1971, p.22). 
A partir dessa premissa, compreendemos que as relações intersubjetivas artista/criação/observador são de natureza fenomenológica e se dinamizam por meio da subjetividade do artista, neste caso Jackson Ribeiro, a subjetividade da sua expressão artística e a intencionalidade dessa expressão que também motiva a experiência de pensamento do observador/pesquisador. O pesquisador, por sua vez, ao cerca o fenômeno através da observação, situando a criação artística e identificando sua historicidade, é capaz de perceber as qualidades dessa experiência.

“(...) a qualidade não é nunca sentida imediatamente e que toda consciência é consciência de alguma coisa. Esta "alguma coisa" não é aliás necessariamente um objeto identificável. Há duas maneiras de se enganar sobre a qualidade: uma é fazer dela um elemento da consciência, embora ele seja objeto para a consciência, tratá-la como uma impressão muda ainda que tenha sempre um sentido, a outra é crer que esse sentido e esse objeto, no nível da qualidade, sejam determinados". (MERLEAU-PONTY, 1971, p.23).

Por fim, podemos descrever nossa construção metodológica: situamos um processo poético, identificamos a historicidade das obras museológicas quem compreendem esse processo, percebemos sinais que orientam a construção de uma linguagem e, por fim, apreendemos uma realidade interna. A realidade interna é um conjunto de qualidades que apreendemos a partir da experiência com a obra de arte, que em conjunto compreendem um sentido particular que atribuímos a uma relação entre o social e o sensível. O sentido da palavra social é fornecido por experiências anteriores no discurso dos quais aprendemos a usá-lo, tais como as compreensões sociológicas sobre a modernidade, arte e sistema industrial desenvolvidas nos capítulos anteriores. Assim, quando colocamos em suspensão o termo social, tal como o utilizamos relacionado ao termo sensível, necessariamente colocamos em suspensão a nossa experiência que revela esse sentido particular, apreendido, fornecido por outras experiências anteriores. Ou como sugerimos no título desse capítulo, uma dupla compreensão: o social envolvido pelo sensível ou uma construção metodológica de compreensão da obra de arte. 


\section{CONSIDERAÇÕES FINAIS: UMA EXPERIÊNCIA DE PENSAMENTO A PARTIR DA EXPERIÊNCIA COM A OBRA DE ARTE}

O "motivo central" (MERLEAU-PONTY, 1945, 208) da nossa experiência com a obra de Jackson Ribeiro foi a questão da sucata, o uso inicial que o artista empregava aos objetos e sua inquietação. Nesse sentido, o motivo é o que nos guia, pois tudo nasce a partir desse questionamento, mas ao mesmo tempo o motivo é aquilo que surge com a experiência de pensar com a obra de arte. Tal como o trabalho de um artesão, cujo o motivo engendra e orienta uma série de ações, nossa experiência de pensamento com a obra de Ribeiro nos orienta a uma articulação de ideia, conceitos e situa nosso pensamento dentro de uma corrente filosófica onde dialogo com alguns mestres. Encontramos na nossa experiência de pensamento a história da nossa filosofia, como um ouvinte encontra o eco de um som. Não buscamos nos cercar de um vocabulário que fosse meramente de citação, como se as palavras desse ou daquele filósofo estivessem a serviço do nosso pensamento, o presente trabalho buscou analisar a obra de Jackson Ribeiro de maneira que pudéssemos entender nossa própria experiência, circunscrevendo nosso "campo de pensamento" (CHAUÍ, 2002, p.23).

Entendemos que o poeta revela seu argumento através da sua criação. Penetra no campo da sensibilidade e percebe nuances delicadas, invisíveis aos olhos. A poesia não está guardada exclusivamente no ato criador do artista, ela se desperta quando experimentamos a obra, quando vivemos as emoções dessa experiência. Inicialmente, é comum acreditarmos que o artista dá origem a obra de arte, certamente em virtude das questões filosóficas a cerca do ato criador. Não seria prudente reduzirmos a obra de arte ao ato criador, ignorando a experiência do observador, que é um fato que instaura as interrogações filosóficas, dialoga 
com uma linguagem específica e coloca-se como questionador da sua própria experiência. A experiência sensível é também criadora, exige que o observador esteja disponível à intuição e entregue as diversas tramas e possibilidade sensoriais. Quando o observador percebe a realidade interna da sua relação com a obra de arte, ele pode incorrer na ilusão de tentar capturar e avaliar essa realidade. Esta atitude guarda as marcas de uma ciência de sobrevôo, hierárquica e distante da verdade, que não percebe que a realidade interna da sua relação com a obra de arte convida o indivíduo a experiência, reconstruindo-se e transformando-se; na arte, a realidade faz parte de uma subjetividade que pode ser interpretada, representada, mas, sobretudo, compreendida. E nesse momento, nossa experiência sensível com a obra de arte torna-se criação. E novamente são palavras de um poeta, "Digo: o real não está na saída nem na chegada: ele se dispõe para a gente é no meio da travessia” (Guimarães Rosa).

E a partir do motivo central costuramos o processo poético de Ribeiro e não nos furtamos a chegar em um terreno maior que é o das Decorrencias Modulares. Certamente, a fase poética das D.M. precisa ser compreendida também enquanto um diálogo com as obras de Lygia Clark, Helio Oiticica e lygua Pape, o que renderia um trabalho anílitico mais exaustivo, ampliando nosso campo de pensamento. Nosso trabalho, ousa revelar a partir do pensamento filosófico mais um artista-pensador, importante para entender a arte contemporânea, e por outro lado esquecido pela História da Arte. Jackson Ribeiro expressou e ao expressar ele também compartilhou conosco seu processo poético. Não existe uma genialidade na sua obra, o que há é a simplicidade com a qual ele se relaciona com a sucata e todos sabemos que é sucata. Na verdade, quando o artista abstrai da sucata uma forma e constrói algo sobre o espaço, ele ressignifica o espaço com a construção formal, mas é o observador quem vai julgar uma determinada figuração. A qualidade não é um elemento da consciência, é uma propriedade do objeto. O que é mais fascinante é quando percorremos o olhar sobre todo o texto visual, cada obra em sua fase e a busca do artista em comunicar. Essa angústia gera o jogo das decorrências modulares e dessa maneira Ribeiro nos questiona a autoria e a criação artística. Ele nos desafia, em uma interação de memória social e sensibilidades. O jogo acrescenta o que já estava escrito nos objetos ou esculturas: quem lê uma obra de arte é motivado a sentir e suas sensações não estão alheias a vida social. Eis o que compreendemos como a interface poética entre o social e o sensível na obra de Fernando Jackson Ribeiro.

Há, na experiência sensível com a obra de arte, aspectos que situamos e destacamos na experiência com a arte contemporânea. Primeiramente, Jackson Ribeiro reporta-se ao seu cotidiano e cria uma identidade para sua linguagem artística. O cotidiano é fluido e leve, tem 
forma e cor, mas também é turvo e pesado é natureza e sucata. O social é verso e reverso. $\mathrm{O}$ primeiro olhar, aquele desatento, descomprometido, sem paciência e sem vontade de pensar, pode julgar e resumir as imagens de Ribeiro por suas distorções e formas não finalizadas. Eis a provocação do artista: não é o fim conclusivo que lhe interessa, nem a imagem congelada de um instante, mas é a constante transformação que as formas se definem na experiência sensível do observador. Ribeiro desafia sua técnica e desenha no espaço com massa, volume e movimento. Quando conhecemos a obra de Jackson Ribeiro, naturalmente, nos enveredamos na busca sobre sua história, suas incursões, as possíveis influências, sua formação ou referência artística. Ora, os objetos de Jackson Ribeiro deixam-se entrever como algo que está além da escultura, eles se manifestam de modo impetuoso e expandem a disciplina, perpassando uma crítica à categorização clássica do objeto artístico. As composições com uso da pedra e do ferro se revelavam através da colagem, e nos anos 1960 foram consideradas pelo circuito de arte como assemblages.

A construção da linguagem de Jackson Ribeiro é uma aventura por caminhos inquietantes para o artista, quando sua técnica construtiva é desafiada pelos materiais que lança-mão para composição. Muito embora haja uma disciplina que conjuga técnica e materiais, ressaltamos a subjetividade do artista impregnada na sua maneira de abstrair as formas, dadas como os ready-made de pedra ou construída como a geometria das Decorrências Modulares, configuradas tal como um alfabeto capaz de elaborar uma imagem que é sensível ao olhar do observador. A linguagem elaborada por Jackson Ribeiro é bem resolvida enquanto tal, mas ela é incompleta na sua condição paradoxal de estar margeada por significações, interpretações aludidas por seus observadores, sem necessariamente possuir qualquer uma das significações que lhe é dada. Formas humanas, míticas, animalescas, a imagem pode ser figurativa ou simplesmente ser a solução de um olhar atento às formas e dotado de uma sensibilidade de conjugá-las em um determinado espaço. O artista usa sinais para dar sentidos à obra, ou deixá-la aberta às significações que os observadores vão lhe atribuir. Torna-se redundante afirmar, mas é importante ratificar que a obra de Ribeiro é aberta às qualidades e sentidos, despertadas na nossa experiência. E, portanto, o pensamento do artista deixa uma questão impensada, que será desenvolvida, maturada, costurada com o pensamento do observador. $\mathrm{O}$ uso da sucata de ferro, presente principalmente na primeira e na segunda fase poética do processo do artista, carrega um sentido de crítica à industrialização e à modernidade. Por outro lado, também pode ser a apropriação formal, com contenção e equilíbrio, de objetos encontrados e estudados esteticamente. $\mathrm{O}$ artista sente, pensa e expressa, e sua expressão ativa um movimento de acercar significados que se aproximam da obra, 
costurando um sistema de ideias que não pertencem ao artista ou a obra, mas está em ligação estreita com o olhar do outro. Sem dúvida a obra é carregada dos sentidos do artista, que estão relacionados a sua experiência. Entretanto, durante a leitura da obra, esses sentidos estão em contato conosco, em diálogo com nossa subjetividade, e os significados que atribuímos à obra é a expressão da nossa experiência nessa relação intersubjetiva. Essa relação intersubjetiva (artista/criação/observador) é fundadora de uma realidade que tratamos como a relação do social e o sensível, que ganha visualidade através da linguagem da obra de Jackson Ribeiro. Assim, nossa interrogação se orientou à linguagem da obra de Jackson Ribeiro, ou ainda, nossa experiência de pensamento se orientou em interrogar nossa experiência com a obra de Ribeiro, capaz de nos abrir a percepção sobre uma realidade interna que existe quando nos relacionamos com a obra. O fenômeno que cercamos é percebido na expressão escultórica do artista, aquele que cria sua expressão, ou seja, aquele que no momento que cria também expressa, imprimindo no objeto uma construção sem igual que o faz ser síntese de uma nova significação, aberta para nós, sem previsão de quem se comunica e do significado que lhe será empregado. Jackson Ribeiro nos convida a reencontrar o que já sabemos a respeito da vida, ele provoca significações existentes, poéticas ou formalistas, tornando-as estranhas e familiares, como se as significações sempre existissem, ainda que inéditas. Os sentidos provocados pela obra de Jackson Ribeiro são como os faróis do poema homônimo de Charles Baudelaire:

"Essas blasfêmias e lamentos indistintos,

Esses Te Deum, essas desgraças, esses ais

São como um eco a percorrer mil labirintos,

E um ópio sacrossanto aos corações mortais!”.

(Charles Baudelaire, 2012, p. 144)

Não duvidamos que há uma provocação à industrialização, colocando uma questão de debate sobre a modernidade. Quando recolhe os lixos de ferro descartados pela modernidade, o artista lança mão da sua liberdade de compor uma imagem, evidenciando a natureza do seu material e do ato da sua técnica, que o nosso olhar de observador logo percebe e convidado a experiência: são imagens poéticas onde cada objeto é mais do que a materialização de um ato criador momentâneo, é uma experiência sensível com a construção do espaço.

Acreditamos ter encontrado o caminho mais fiel a um dos objetivos dessa pesquisa: colocar em suspensão nossa experiência com a obra de arte. A experiência com a obra de um 
artista que figura acervos museológicos entrelaçou também um diálogo do pesquisador com os arquivos de museus. Essa relação com os documentos, como fontes de informações contextuais, pode parecer o reflexo de uma formação fundada na cultura arquivística e documental. No entanto, as leituras que obtivemos em nosso processo revelam que a experiência com a obra de arte não necessita de uma fundamentação documental, pois são os dados referentes às qualidades e sentidos atribuídos a esta experiência que motivam nosso pensamento. As orientações metodológicas que nortearam o estudo buscaram circunscrever um campo para pensar e, certamente, o que pode causar um estranhamento aos rigores de uma academia formalista e com orientações positivistas, é que entendemos nosso pensamento como “delimitação aberta” (CHAUÍ, 2002, p. 148), uma postura fenomenológica alternativa à ideia de síntese aristotélica, apropriada pela metodologia causalista. Assim, apresentamos uma reflexão sobre nossa experiência com o estudo de um processo poético, dialogando com os usos que fizemos dos dados de arquivos, sistematizados e construídos pelas instituições museológicas.

É importante destacar que nosso objetivo com os documentos dos arquivos de museus e arquivos de pessoas foi precisamente para nos cercar de dados contextuais, a fim de conhecer a historicidade dos trabalhos de Jackson Ribeiro. Não queríamos com isso provar qualquer premissa a partir de fontes documentais, mas estávamos diante de uma situação real: as obras de Ribeiro, que trabalhamos ao longo da pesquisa, pertenciam em sua maioria à coleções de museus; por outro lado, com a morte do artista seu arquivo pessoal foi adquirido pelo Museu de Arte Contemporânea do Paraná (MAC PR) e, dessa maneira, a memória dos fatos, do processo poético, das falas dos artista estavam circunscritas apenas ao arquivo de museu e às narrativas dos amigos. Novamente nos esbarravamos em outro problema: a memória. Esta por sua vez nunca nos foi um objetivo a ser esmiuçado, sobretudo, porque já é compreensão entre as filosofias e as ciências humanas e sociais que a memória é seletiva e incorre sobre o campo do discurso. Inicialmente, quando nos interessamos pelos escritos dos críticos da obra de Jackson Ribeiro, entendemos que a análise de discurso desvirtuaria a experiência de pensamento dos críticos: a crítica de arte nos fornecia dados das experiências dos outros observadores da obra de arte que ora nos aproximávamos. As entrevistas realizadas com os amigos do artista serviram para nos aproximar de realidades culturais, onde a obra de Ribeiro emergiu. A partir das narrativas de outros observadores, pudemos compreender as diferentes percepções e experiências complementares a mesma obra. Isso nos faz entender que a obra de arte, ao motivar experiências que despertam qualidades e sentidos, tem dimensões específicas nas relações intersubjetivas quando conhecemos o ponto de vista de outro 
observador. Para que pudéssemos falar sobre as relações intersubjetivas que há entre o artista, a obra de arte e o observador, ao passo que precisávamos compreender nossa própria experiência enquanto observador, também buscamos conhecer dados da experiência de outros observadores. Tendo em vista esta trama de sentidos e qualidade, reconhecemos que há o "outro" observador, outro corpo que se alterou quando olhou, aproximou ou sentiu a mesma obra de arte que ora observamos. Embora seja nossa relação com a obra de arte e as motivações do artista que cercam nosso pensamento, não poderíamos negar a existência de outros olhares, pois eles estão lá desde sempre e tiveram experiência com a criação artística.

Sem incorrer pelo equívoco de pensar que o trabalho se localiza nessa ou naquela escola ou corrente artística, entendemos que das suas formas advenham um "desenho intuitivo", fruto de uma criação espontânea. O artista percebe sua realidade e sua preocupação se traduz na linguagem da forma, seja da pedra, do ferro ou de módulos geometricamente construídos. Intuitivamente, ele parte de uma forma inicial e constrói. O resultado é o surgimento de um desenho escultórico cujo movimento dado pela forma é forjado pelo olhar do observador que cria uma imagem. Não é apenas a linguagem de uma construção espacial das formas que desenha figuras, mas é também a experiência sensível do observador, que envolve suas emoções e afetos. Finalmente, entendemos que a origem da obra de arte precede a criação do artista: antes de identificar a pedra, o ferro e as formas geométricas na escultura, já há escultura nas formas e volumes percebidos pelas experiências sensíveis.

Finalmente, Entendemos que o social e o sensível é um fenômeno, que ganha visualidade através da linguagem de Jackson Ribeiro e da experiência que o observador tem com a obra de arte. Dessa maneira, entendemos que as relações intersubjetivas que fundam esse fenômeno de visualidade são experiências com o Ser da linguagem, que tem que como pano de fundo a historicidade dos indivíduos e o contexto por eles vivido, é portanto social e sensível. Considerando essas atribuições do trabalho artístico e da experiência que a arte motiva, concluímos que a obra de arte, enquanto experiência, é uma forma de pensamento que nos exige o esforço de compreender uma realidade interna que se funda na relação intersubjetiva o artista, a criação e o observador. 


\section{BIBLIOGRAFIA}

ANJOS, Augusto. Eu e outras poesias. Rio de Janeiro: Nova Fronteira, 2011.

AMARAL, Aracy. Modernidade e identidade: as duas Américas Latinas ou três, fora do tempo. In. BELLUZO, Ana Maria de Moraes (org.). Modernidade: vanguardas artísticas na América Latina. São Paulo: UNESP, 1990. p. 171-184.

ARANHA, Carmen Sylvia Guimarães. Exercícios do olhar: conhecimento e visualidade. São Paulo: Editora UNESP; Rio de Janeiro: FUNARTE, 2008.

BAUMAN, Zygmunt. Modernidade Líquida. Rio de Janeiro: Jorge Zahar Editor, 2001.

BELTING, Hans. O fim da história da arte: uma revisão dez anos depois. São Paulo: Cosac Naify, 2006. 
BENJAMIN, Walter. "A obra de arte na era da sua reprodutibilidade técnica". In. Magia e técnica, arte e política: ensaios sobre literatura e história da cultura. São Paulo: Brasiliense, 1994. p. 165 - 196.

BOURDIEU, Pierre. Questions de sociologie. Paris: Les Éditions de Minuit, 1984.

BRITO, Ronaldo. Neoconcretismo: vértice e ruptura do projeto construtivo brasileiro. São Paulo: Cosac \& Naify, 1999.

CAUQUELIN, Anne. Arte contemporânea: uma introdução. São Paulo: Martins, 2005.

CHAÍ, Marilena. Experiência de pensamento: ensaios sobre a obra de Merleau-Ponty. São Paulo: Martins Fontes, 2002.

CENTRO Empresarial Rio. Catálogo da exposição Jackson Ribeiro Os Elementares: 29 de fevereiro a 7 de abril de 1984. Rio de Janeiro: Centro Empresarial Rio, 1984.

DANTO, Arthur Coleman. After the end of art: contemporary art and the pale of history. New Jersey: Princeton University Press, 1997.

DOCTORS, Márcio. A lógica secreta dos arabescos. O Globo, 26 jan. 1991.

LAPLANTINE, François. Le social et le sensible: introduction à une anthropologie modale. Paris : Téraèdre, 2005a. , La description ethnographique. Paris: Armand Colin, 2005b.

LEITE, José Roberto Teixeira. Os delírios do Sr. Reis Junior. Coluna Artes Visuais. [?], 04 set. 1960.

LEITE, José Roberto Teixeira. Brasile. In. Catálogo da $31^{a}$ Bienalle Internazionale d'Arte di Venezia. 16 Giugno - 17 ottobre, 1962. p.115-116.(Texto de apresentação dos artistas brasileiros na Bienal de Veneza de 1962).

LISBONA, Diane. Jackson, a vitalidade do ferro. O Estado do Paraná, 22 fev. 1974.

LISPECTOR, Clarice. A hora da estrela. Rio de Janeiro: Rocco, 1998.

LOPES, Maria Adélia. Jackson Ribeiro. Jornal Nicolau, Curitiba, nov. 1988. p.6-8.

MERLEAU-PONTY, Maurice. Phénoménologie de la perception. Paris: Gallimard, 1945. , O visível e o invisível. São Paulo: Perspectiva, 2007. , A prosa do mundo. São Paulo: Cosac e Naify, 2012.

MORAIS, Frederico. Jornal O Globo. Rio de Janeiro, 02 mar. 1984.

OITICICA, Hélio. Jackson. Rio de Janeiro, 1968. Disponível em: $<$ http://www.itaucultural.org.br/aplicexternas/enciclopedia/ho/index.cfm?fuseaction=docume ntos\&cod=2\&tipo=2>. Acesso em: 02 jun. 2008.

, Nota sobre a escultura de Fernando Jackson Ribeiro. Rio de Janeiro, 1964. 
<http://www.itaucultural.org.br/aplicexternas/enciclopedia/ho/index.cfm?fuseaction=docume ntos\&cod=2\&tipo=2>. Acesso em: 02 jun. 2008.

, Jackson Ribeiro: Do Totem às Decorrências Modulares, Rio de Janeiro, 1979.

Disponível

em:

$<$ http://www.itaucultural.org.br/aplicexternas/enciclopedia/ho/index.cfm?fuseaction=docume ntos\&cod=2\&tipo=2>. Acesso em: 02 jun. 2008.

PESSOA, Fernando. Poesia completa de Alberto Caeiro. São Paulo: Companhia das Letras, 2005.

PEDROSA, Mário. Missão cumprida. Jornal do Brasil. Rio de Janeiro, 10 ago. 1960.

PORTEIRO do Inferno continua abandonado. O Norte, 13 out. 1966(?).

RESTANY, Pierre. Jackson Ribeiro, sculptures. Galerie Debret. Paris, 17 fev. 1967.

, Os novos realistas. São Paulo: Perspectiva, 1979.

RICKEY, George. Construtivismo: origens e evolução. São Paulo: Cosac \& Naify, 2002.

ROSA, João Guimarães. Grande Sertões: veredas. 19 ed. Rio de Janeiro: Nova Fronteira, 2001.

ROUANET, Paulo Sérgio. As razões do iluminismo. São Paulo: Companhia das Letras, 1987.

SCHUTZ, Alfred. Le chercheur et le cotidien. Phénoménologie des sciences sociales. Paris:

Meridiens Klincksieck, 1987.

SOARES, Stênio. "Uma poesia surda e rouca": a obra de Jackson Ribeiro em acervos museológicos brasileiros. In: Kátia Canton. (Org.). Poéticas da natureza. São Paulo: PGEHA/MAC USP, 2009. p. 63-68.

. O escultor do ferro. Cadernos de cultura - Boletim de arte e cultura, João Pessoa, p. 19 - 21, 01 abr. 2010a.

. "Arcaísmo expressivo": a poética escultórica de Jackson Ribeiro. João Pessoa: Funarte/Fundação Ormeo Junqueira, 2010b. (comunicação oral).

. "Seria a subjetividade do pesquisador um problema? Reflexões metodológicas para uma pesquisa interdisciplinar em arte". PGEHA USP. Interdisciplinariedade, Transdisciplinariedade no Estudo e Pesquisa da Arte e Cultura. São Paulo: PGEHA USP, 2010c. p. 335-339.

"Arte e educação: um estudo de caso a partir do Jogo dos Elementares de Fernando Jackson Ribeiro”. João Pessoa: UFPB/UFPE, 2010d. (comunicação oral).

SOUZA, Maria Eduarda Alves de. O escultor de ferro. Jornal do Brasil, Rio de janeiro, 30 out. 1978. 
ZANINI, Walter (org). História geral da arte no Brasil. São Paulo: Instituto Moreira Salles, 1983. 2v. 